\title{
Policy interventions, perceptions, and pro- environmental behavior for sustainable oil palm cultivation in Indonesia
}

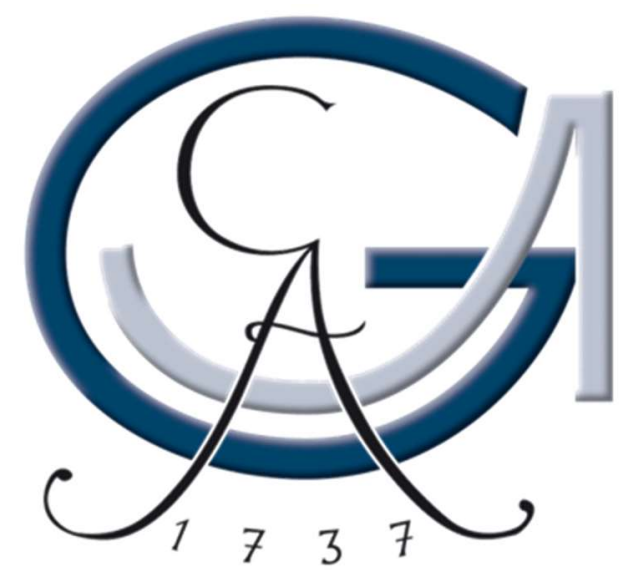

\author{
Dissertation \\ to obtain the doctoral degree in the International Ph.D. Program for \\ Agricultural Sciences (IPAG) at the Faculty of Agricultural \\ Sciences, Georg-August-University in Göttingen, Germany \\ presented by \\ Karina Brenneis
}

born in Mosbach, Germany 
First supervisor: $\quad$ Prof. Dr. Meike Wollni

Second supervisor: Prof. Dr. Oliver Musshoff

Third supervisor: Prof. Dr. Matin Qaim

Date of defense: November 4, 2021 


\section{Summary}

In the last decades, oil palm cultivation has increased rapidly to meet the rising demands for vegetable oils worldwide. While in the 1970s, two million tons of palm oil on 3.3 million hectares of land were produced worldwide, production levels have increased by 36 times in 2019, to around 72.3 million tons on 28.3 million hectares of land. There are two main reasons for the rapid expansion. Oil palms can produce more tons per hectare compared to any other crop. In addition, it is very versatile in its use and can be used in the food industry, for cosmetics, industrial and agrochemical products, and biodiesel.

Indonesia has been the biggest oil palm producer worldwide since 2008. The oil palm boom has brought economic benefits such as increases in incomes and living standards for the producers and others along the value chain. Besides the economic benefits that the oil palm industry has entailed, the massive land-use transformation and the common management practices applied have led to immense environmental degradation that affects the local population, rural and urban, but also beyond borders.

Against this background, the focus of this dissertation is on the economic and environmental tradeoffs of oil palm cultivation. The dissertation also addresses the environmental dimension of oil palm cultivation by examining climate change perceptions, environmental concern, and pro-environmental behavior among the local population. The present dissertation comprises three essays and addresses three broad research objectives: First, to assess the adoption decisions of an agricultural technology that generates positive environmental effects among small-scale oil palm farmers to support sustainable oil palm cultivation; second, to examine the environmental concern and proenvironmental behavior among the local population in a setting characterized by a rapid land-use transformation in the Global South; and third, to understand climate change perceptions among smallscale oil palm farmers in a setting of rapid land-use change. The analysis of the three essays relies on primary data collection in Jambi, Sumatra, Indonesia, from 2019 and 2020 and consists of a total of 757 respondents, where 408 are oil palm farmers and 349 are respondents from Jambi City. This research was conducted in the frame of the Collaborative Research Center (CRC) 990: Ecological and Socioeconomic Functions of Tropical Lowland Rainforest Transformation System (EFForTS) in Indonesia.

The first essay focuses on the adoption of an agricultural technology that is socially desirable and generates positive environmental effects with delayed private benefits for the adopters. In the case of welfare-enhancing technologies such as improved seeds or fertilizer, scholars have shown that subsidies can be an adequate instrument to motivate adoption. Yet, for agricultural technologies such 
as native tree planting, that are socially desirable and need maintenance evidence remains limited on how to stimulate adoption, tree survival, and additional investments into this technology effectively. We implemented two policy interventions with oil palm smallholders to analyze the adoption of native tree planting, tree survival, and engagement in additional planting efforts. In the first treatment, oil palm farmers received information with regards to native tree planting and three native tree seedlings for free (subsidy treatment). In the second treatment, oil palm farmers received the same information about native tree planting and had then the opportunity to buy three native tree seedlings through an auction mechanism (price treatment). Our results show that under a subsidy scheme, farmers have a higher probability to plant the tree seedlings they received and they also plant more tree seedlings compared to the treatment where farmers had the opportunity to buy the seedlings. The higher planting intensity in the subsidy treatment led to a higher tree survival rate. Yet, we find a tendency towards more additional planting efforts in the price treatment pointing towards crowding-out effects of farmers in the subsidy treatment. The cost-effectiveness analysis that we conducted, reflects our results when focussing only on the trees that we provided. More tree seedlings were planted in the subsidy treatment which was also more expensive compared to the price treatment. The costeffectiveness is higher for the price treatment when including additional planting efforts. This is driven by few farmers though.

The second essay addresses environmental concern and pro-environmental behavior among the local population living in an oil palm cultivating hotspot in the Global South. Scholars have shown that negative environmental repercussions have an effect on environmental concern and the engagement in pro-environmental behavior of individuals. Environmental concern and pro-environmental behavior both indirectly or directly influence decisions made about the sustainable use of natural resources. For policymakers, it is highly relevant to understand how the local population thinks and behaves to develop more targeted policy and outreach instruments to support sustainable land-use changes. While there exists literature on environmental concern and pro-environmental behavior in industrialized nations focusing on rural-urban differences, evidence is scarce for societies in the Global South. In this study, we examine environmental concern and pro-environmental behavior in the Global South where people live in an oil palm cultivating hotspot and in a setting characterized by a rapid land-use transformation. Our results reveal that overall rural residents are significantly more concerned than urban respondents. This is true for general environmental concern, as well as for the specific oil palm concern which shows that oil palm farmers might be aware of the environmental effects of oil palm cultivation. We also find that connectedness with nature, connectedness with oil palms, and the preference for more heterogeneous landscapes are important determinants for environmental concern. For pro-environmental behavior, we find that rural respondents engage more. A higher connectedness with oil palms decreased the engagement in pro-environmental behavior 
among the respondents while the hours participated in other environmental activities are positively correlated with pro-environmental behavior.

The third essay of this dissertation analyzes climate change perceptions of Indonesian small-scale oil palm farmers. The implications that climate change has on agriculture and vice versa are already visible today. On the one hand, the number and severity of climate change-related weather events have increased. On the other hand, agriculture contributes to climate change with the release of huge amounts of $\mathrm{CO}_{2}$. Much of the global warming that is experienced today and for the next 30 years is based on emissions that have already been released into the atmosphere. Yet, the degree of future global warming highly depends on emissions of today and the near future. Hence, adaptation strategies have to become a central strategy today to slow down and decrease the implications of climate change and agriculture on each other in the long term. To do so, climate change perceptions of individuals need to be well understood to develop suitable strategies. In this regard, scholars have shown that farmers seem to be aware of climate change and its potential effects to varying degrees. Important sociodemographic factors that are associated with climate change perceptions are education, age, and wealth amongst others. Yet, evidence remains limited for climate change awareness and the perceived affectedness of small-scale oil palm farmers living in a setting of rapid land-use transformation. In this study, we analyze determinants of climate change awareness and perceived affectedness of small-scale oil palm farmers. Our results reveal that about three-quarters of the respondents are aware of climate change and almost 60 percent feel personally affected by it. Important factors associated with climate change awareness and perceived affectedness are education, age, and wealth. Finally, the experience of extreme weather events seems to not strongly be associated with the climate change perceptions of the oil palm farmers.

This dissertation contributes to the actual state of research with regards to the economic and environmental trade-offs of oil palm cultivation as well as to the environmental dimension by examining climate change perceptions, environmental concern, and pro-environmental behavior among the local population. The results indicate firstly, that the adoption of native tree planting can be enhanced by a policy mix that involves the distribution of subsidized tree seedlings as well as value chain development to address multiple barriers to native tree seedlings. Secondly, environmental concern and pro-environmental behavior differ significantly between rural and urban residents, and hence, to overcome a lack of disconnectedness between the general public and the agrarian transformation and strengthen environmental concern and pro-environmental behavior, the spread of information and environmental education seem to be promising. Finally, to support the development of suitable climate change adaptation strategies relevant knowledge needs to be spread among the farmers to create more climate change awareness. Furthermore, as the financial means of 
the farmers differ but are associated with being better equipped regarding adaptation measures, especially, the poorer farmers need to receive suitable support when it comes to the adoption of adaptation measures taking potential barriers, e.g. financial means, into account. 


\section{Acknowledgments}

After three years this unique and intense journey comes to an end. Without the support of many people, this time would not have been the same. First and foremost I would like to thank my first supervisor Prof. Meike Wollni. Thank you, Meike for trusting me and my decisions. I learned a lot from your guidance and our discussions. The independence you gave me to find my path supporting me whenever I needed, made this journey a great one for me. I would also like to thank my second supervisor Prof. Oliver Musshoff for being on my thesis committee and for the valuable comments on my first paper. Further, I want to thank my third supervisor, Prof. Matin Qaim, for being on my thesis committee and for discussing my second paper, and for the helpful comments.

I wrote this thesis at the Chair of Environmental and Resource Economics in the Collaborative Research Centre 990: Ecological and Socioeconomic Functions of Tropical Lowland Rainforest Transformation Systems (Sumatra, Indonesia) (EFForTS) which is funded by the Deutsche Forschungsgemeinschaft (DFG). I gratefully acknowledge the financial support from the DFG. I am happy that I could be part of such a great research project where I learned a lot as a researcher. On this note, I want to express my gratitude to my colleagues at the Chair of Environmental and Resource Economics for the great working environment. A special thanks goes to you, Katrin. I am glad that I had the opportunity to share an office with you. Thank you for bearing with me when I had so many questions that you had to answer, especially in the beginning. Further thanks go to Ivonne Hein from the EFForTS team in Göttingen for her administrative support. I also want to thank the team in Jambi, Ibu Aiyen, Mega, Rizky, Shara, and Yuking. Thank you for all your help when being in Jambi for the fieldwork. I am grateful that you took such good care of me when I was lying in the hospital. Your visits and the tons of food you brought to the hospital surely made my stay much more tolerable.

I want to extend my gratitude to all the village heads and RT heads for allowing us to do the interviews in their villages and RTs in Jambi City and the respondents who welcomed us into their homes and gave us their time and information by participating in our surveys. Without you, I would not have been able to write this thesis. Thank you. Of course, the data collection would not have been possible either with the great help of my research assistants. I would like to thank all of you, Amrina, Dila, Fitryah, Irham, Juwita, Reza, Rizki, Saut, Wildan, Winda, and Zaki. You all did a great job and I enjoyed the fieldwork with you guys a lot. Thank you for the hard work, the great coffee breaks, the cooking, and the fun we had together. Special thanks also go to Bang Wawan for being the best driver in the field we could have asked for.

For my second field trip, I want to thank Aiden for accompanying me. Your support during this trip was great and I am happy that we could share this experience. 
Furthermore, I want to thank all my wonderful friends. Without you, this journey would not have been the same for me. I don't know what I would do without you and I would like to take the opportunity and thank you all for your friendship and your support. On this note, a special thanks goes to Jessie. Thank you for accompanying me through these three years, for always being there for me, for your honesty, and for the great times we shared. Verena, I am very thankful that we shared a big part of this Ph.D. journey. Thank you for your support, honesty, and humor. I also want to thank the two of you for your support in the final phase of my Ph.D.

Lisa W., thank you for your encouragement to even start a Ph.D. I am very thankful for your support throughout this journey and for always being there whenever I need you. I am grateful to call you my friend. Maike, thank you so much for your statistical support, and our discussions which helped me a lot. Vanessa, and Astrid, even though we don't see each other that often, you have always been there for me, listening to me and supporting me. I am so grateful for having you two in my life.

Felix, my love, I am so thankful for having you by my side. Thank you for your love, your honesty, your encouragement, and your patience with me! Without you, this journey would have been so much harder.

Liebe Mama und lieber Papa, ich danke euch von ganzem Herzen, dass ihr mich immer bedingungslos unterstützt, mich meinen Weg gehen lasst und immer an mich glaubt. Ich weiß, dass das nicht selbstverständlich ist und ich bin unfassbar dankbar dafür. 


\section{Table of contents}

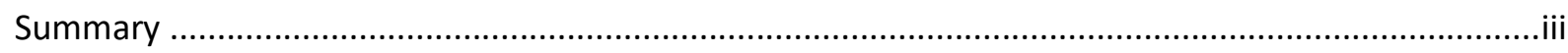

Acknowledgments ................................................................................................................

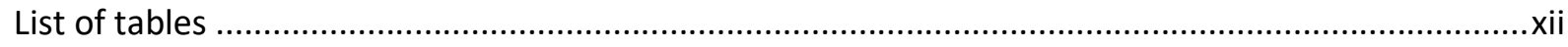

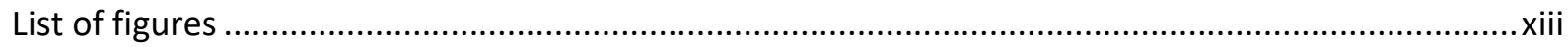

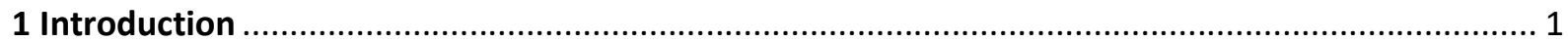

1.1 The oil palm boom and its effects in Indonesia.................................................................... 1

1.2 Research gaps

1.2.1 Policy interventions to adopt agricultural technologies with positive effects on the

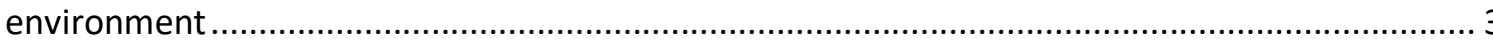

1.2.2 Environmental concern and pro-environmental behavior in an oil palm cultivating hotspot4

1.2.3 Climate change perceptions among small-scale oil palm farmers ....................................... 4

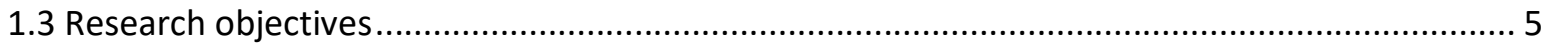

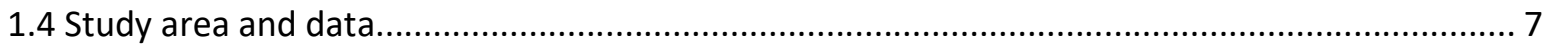

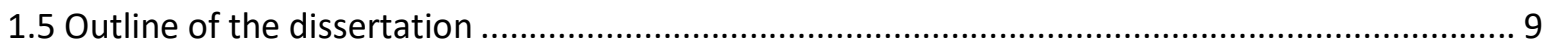

2 How to promote agricultural technologies that generate positive environmental effects?

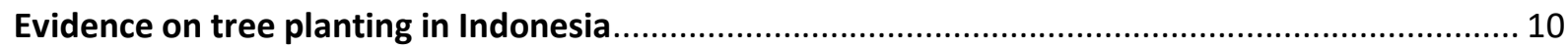

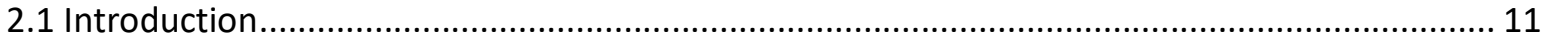

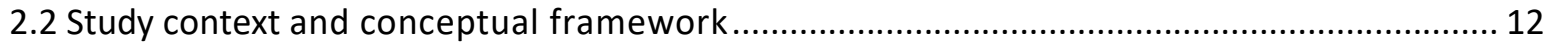

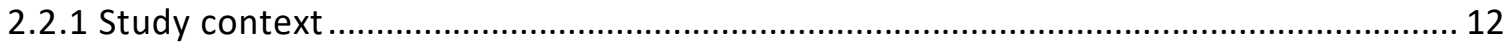

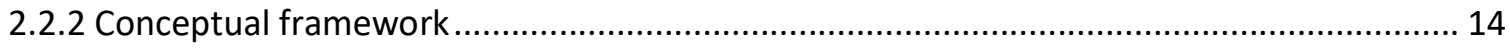

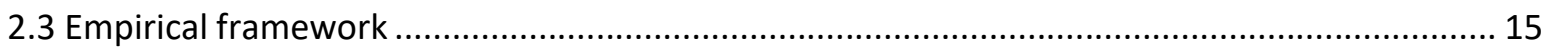

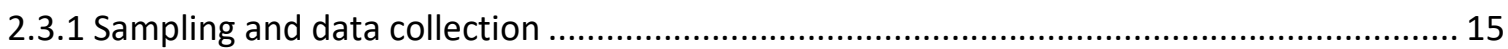

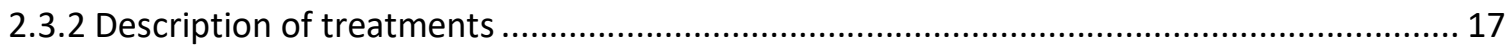

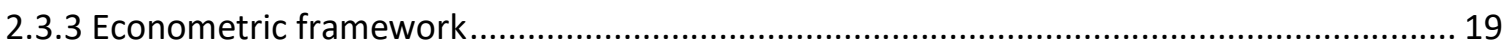

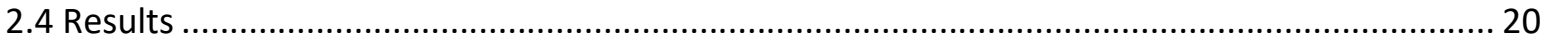

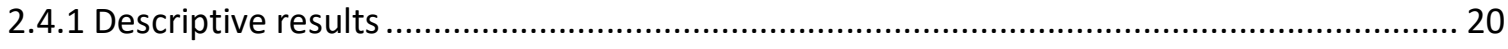

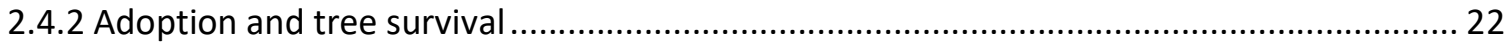

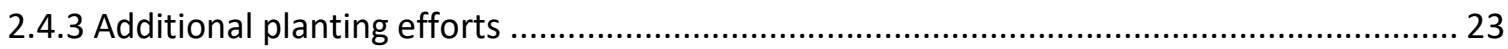

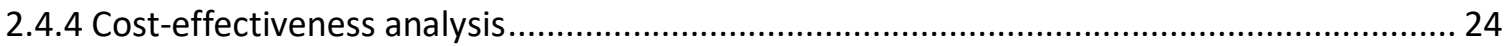

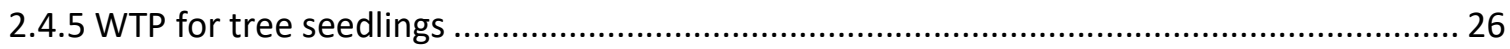

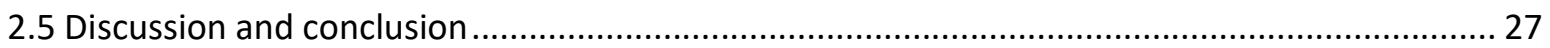

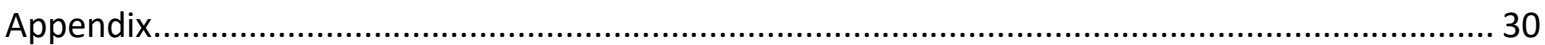


3 Environmental concern and pro-environmental behavior among residents in an oil palm

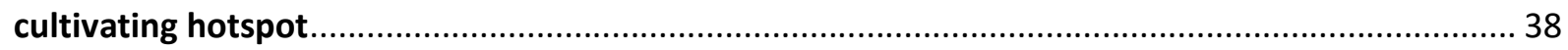

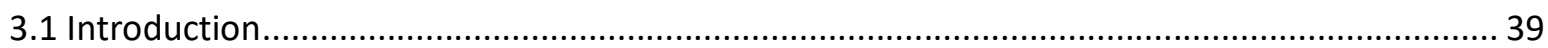

3.2 Oil palm cultivation in Indonesia and its effects on the local population .................................. 41

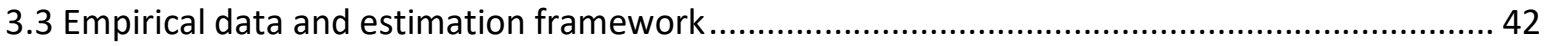

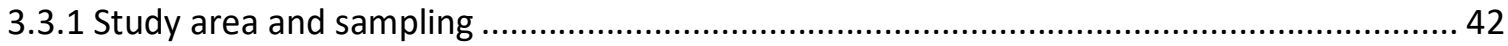

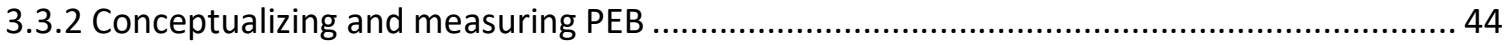

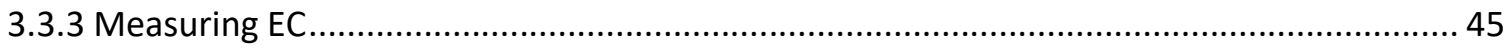

3.3.4 Measuring nature connectedness and social proximity to agriculture................................ 45

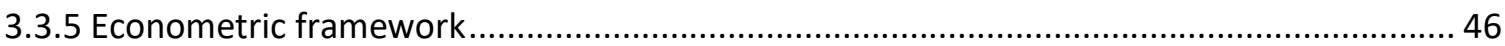

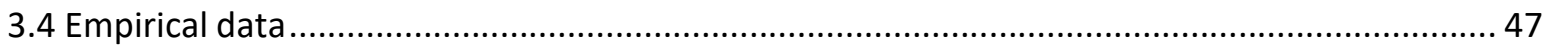

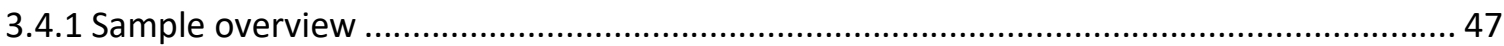

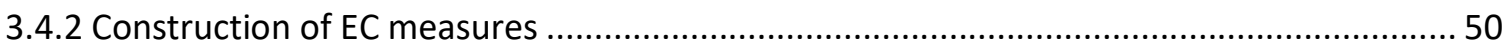

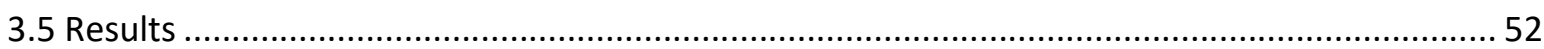

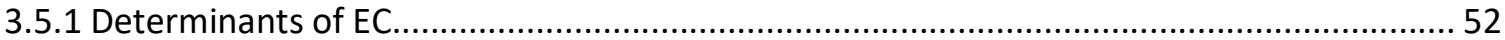

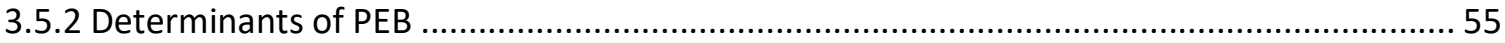

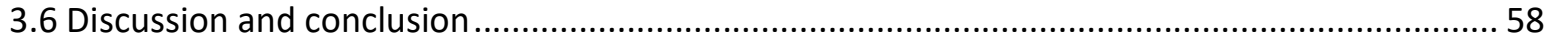

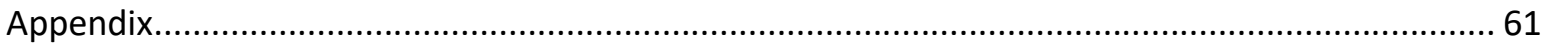

4 Climate change perceptions among small-scale oil palm farmers in Indonesia............................. 65

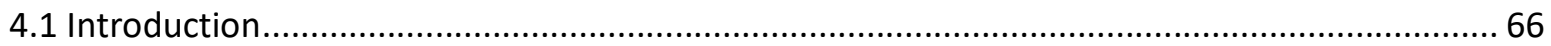

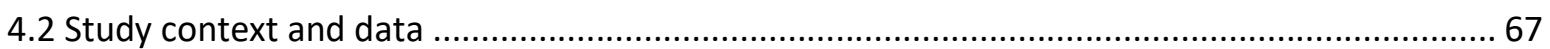

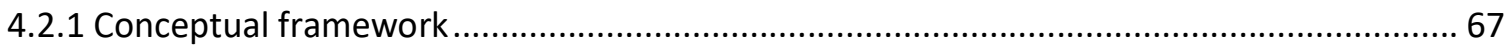

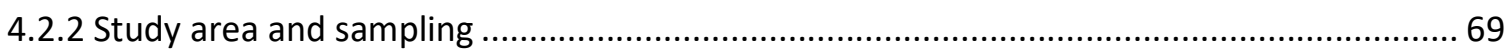

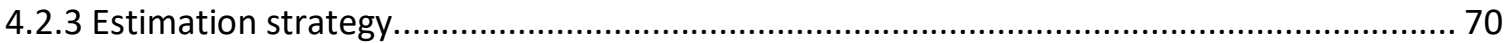

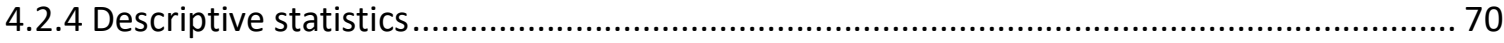

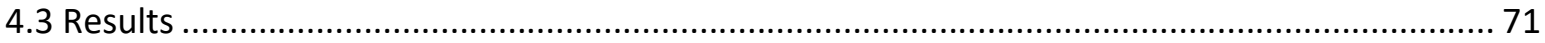

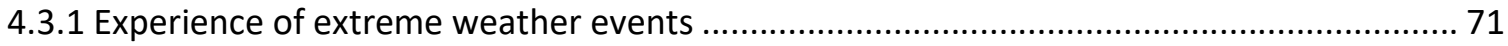

4.3.2 Determinants of climate change awareness and perceived affectedness........................... 72

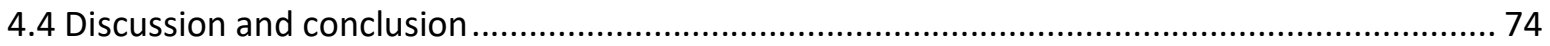

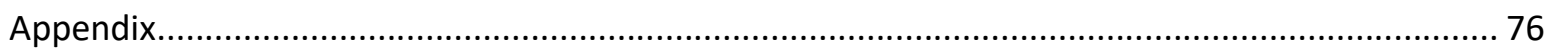

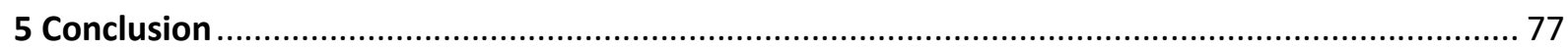

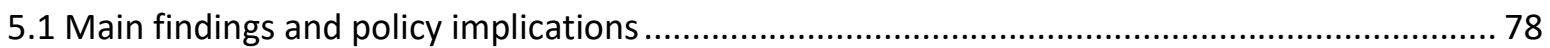

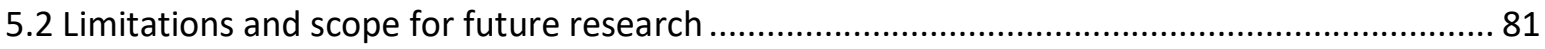

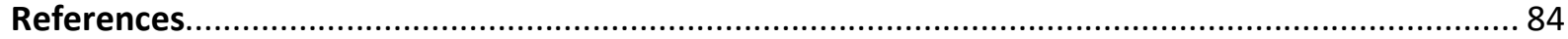

General appendix 
Appendix Chapters 2 and 3

Declarations 


\section{List of tables}

Table 2.1: Description of prices for different tree bundles...................................................................

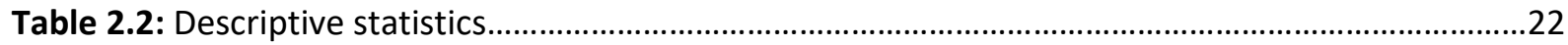

Table 2.3: ITT effects of trees planted and trees that are still alive for trees planted in home gardens, oil palm, rubber, and fallow land.

Table 2.4: ITT effects of trees planted that were obtained by farmers themselves and planted in home gardens, oil palm, rubber, and fallow land.

Table 2.5: Costs associated with each treatment in USD.

Table 2.6: Results from a basic cost-effectiveness analysis for tree seedlings planted in home gardens, oil palm, rubber, and fallow land.

Table 2.7: AME for the sub-sample T2

Table A2.1: ITT effects of planting trees in home gardens, oil palm, rubber, and fallow land.

Table A2.2: ITT effects of planting trees in oil palm and rubber plantations, and fallow land.

Table A2.3: ITT effects for the number of trees alive (three tree seedlings) for trees planted in home gardens, oil palm, rubber, and fallow land.

Table A2.4: ITT effects for the number of trees alive (three tree seedlings) for trees planted in oil palm and rubber plantations and fallow land.

Table A2.5: ITT effects for additionally obtained tree seedlings planted in home gardens, oil palm, rubber, and fallow land.

Table A2.6: Cost-effectiveness for the trees planted in oil palm and rubber plantations and fallow land.

Table A2.7: Cost-effectiveness for the trees planted in home gardens, oil palm, rubber, and fallow land.

Table A2.8: Cost-effectiveness for the trees planted in oil palm and rubber plantations and fallow land.

Table A2.9: AME for sub-sample T2

Table 3.1: Descriptive statistics - sociodemographics.

Table 3.2: Descriptive statistics - nature connectedness and social proximity to agriculture . .51

Table 3.3: Descriptives for NEP scale items. . .52

Table 3.4: Descriptives for oil palm-related concern items......................................................................53

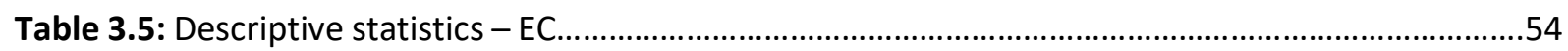

Table 3.6: OLS estimates for general EC (12-item NEP scale) ................................................................55

Table 3.7: OLS estimates for specific oil palm concern.............................................................................56

Table 3.8: Descriptive statistics - self-reported PEBs...........................................................................56 
Table 3.9: Descriptives for donations 57

Table 3.10: Regression results for donation behavior.......................................................................59

Table A3.1: Estimates for donations made using a two-step model...................................................63

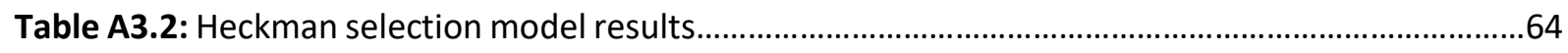

Table 4.1: Descriptives statistics for sociodemographics and wealth indicators...................................72

Table 4.2: Previous experiences with extreme weather events...........................................................72

Table 4.3: Descriptive statistics for climate change awareness and perceived affectedness..................73

Table 4.4: Factors associated with climate change awareness and perceived affectedness...................75

Table A4.1: Factors associated with climate change awareness and perceived affectedness................77

\section{List of figures}

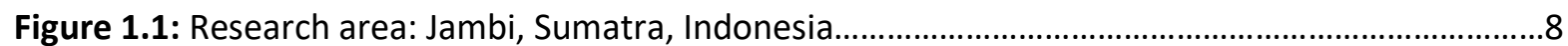

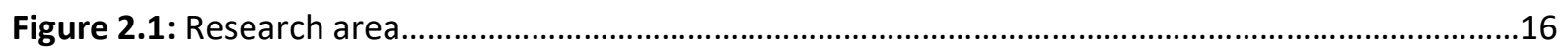

Figure 2.2: Histogram for the WTP of farmers in the price treatment.................................................26

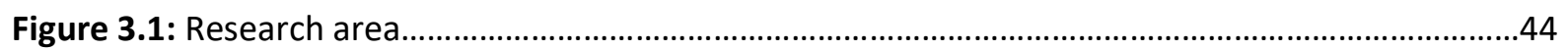

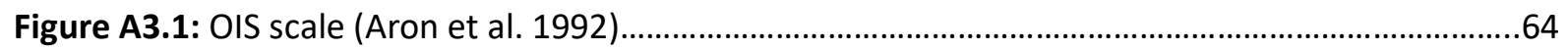

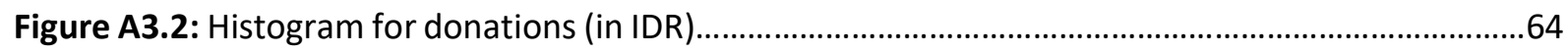

Figure A3.3: Donations for respondents currently in the village (in IDR) ...........................................65

Figure A3.4: Donations for respondents currently living in the city (in IDR) .......................................65

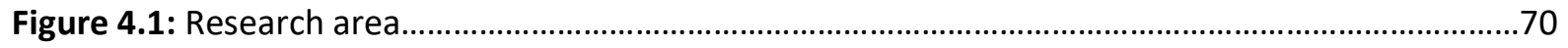




\section{Introduction}

\subsection{The oil palm boom and its effects in Indonesia}

Oil palm is the most significant crop in Southeast Asia and it is associated with a large-scale agrarian transformation (Hall 2009). In the 1970s oil palms were cultivated on 3.3 million hectares of land, compared to 28.3 million hectares of land in 2019 (FAOStat 2021). There are two major reasons for this rapid expansion: Oil palms can produce more tons of oil per hectare in comparison to other oil crops (Qaim et al. 2020) and the oil is versatile in its use, e.g. in the food industry, for cosmetics, industrial and agrochemical products, and biodiesel (Corley and Tinker 2016). About 80 percent of the palm oil produced is for edible use while 20 percent is for non-edible use (Basiron and Weng 2004). In Indonesia, where most of the palm oil is produced, the area for oil palm cultivation has expanded from 637.000 hectares to about 14 million hectares between 1990 and 2019 (FAOStat 2021). Besides largescale commercial investments, smallholder farmers are increasingly involved in the cultivation of oil palms (Euler et al. 2016b). Small-scale farmers in Indonesia manage about 40 percent of the land cultivated with oil palms today (Euler et al. 2016b). While oil palm cultivation has brought economic benefits for many along the value chain, the palms also have incurred negative effects on the environment affecting the local population and beyond borders (Koh and Wilcove 2008; Obidzinski et al. 2012; Lee et al. 2014; Sjahza and Asmit 2019).

Continuing to maintain the economic profitability of oil palms while developing strategies to counteract their negative environmental effects remains a major challenge for Indonesia (Zhao et al. 2006). Against this background, this dissertation focuses on policy interventions that aim to decrease the environmental-economic trade-off in oil palm cultivation. This dissertation also addresses the environmental dimension of oil palm cultivation by examining climate change perceptions, environmental concern, and pro-environmental behavior among the local population living in an oil palm cultivating hotspot.

Among the economic benefits of oil palm cultivation are income increases and improvements in the living standards of the farmers (Gatto et al. 2015). Yet, these benefits are not distributed equally among the farmers. This often depends on land, labor, and capital endowments, and market economy exposure (Euler et al. 2017; Krishna et al. 2017; Santika et al. 2019). Yield gaps between companies and small-scale farmers are also commonly observed (Euler et al. 2016a). Oil palm cultivation is not only an important income source for the farmers; it also created job opportunities for non-farm households (Pacheco et al. 2017; Bou Dib et al. 2018). Furthermore, the oil palm expansion has stimulated local development by private and public sector investments in local infrastructure (such as roads, education, and health) (Budidarsono et al. 2013; Pacheco et al. 2017; Kubitza et al. 2018) which 
might increase employment opportunities in the cities (Budidarsono et al. 2013). As the labor requirements for oil palm cultivation are lower compared to alternative cash crops such as rubber, oil palm farmers can make use of the saved time when switching from rubber to oil palm to diversify income sources and earn off-farm income or manage larger areas of oil palms (Euler et al. 2017).

Concerning the negative environmental effects, the expansion of oil palm monocultures has led to the loss of forest areas, water and air pollution, and a decrease in biodiversity (Feintrenie et al. 2010a; Gibson et al. 2011; Merten et al. 2016; Austin et al. 2017; Dislich et al. 2017; Santika et al. 2019). Management practices commonly applied in the oil palm sector can add to these negative effects (Feintrenie et al. 2010a; Gibson et al. 2011; Merten et al. 2016; Austin et al. 2017; Dislich et al. 2017; Santika et al. 2019). For example, a cost-effective method to clear land for oil palm expansion is to burn the land, leading to air pollution and being responsible for environmental damages, especially in dry years (Varkkey 2013; Naylor et al. 2019). These environmental repercussions, directly and indirectly, affect the local population and their environmental concern and the engagement in proenvironmental behavior. This can then directly or indirectly influence the sustainable use of natural resources (Meinhold and Malus 2005).

In this dissertation, we define environmental concern as "an evaluation of, or an attitude towards facts, one's own behaviour, or others' behaviour with consequences for the environment" (Fransson and Gärling 1999, page 370). Environmental concern reflects a general attitude or a general value orientation (Fransson and Gärling 1999). We define pro-environmental behavior in this work as "behaviour that consciously seeks to minimize the negative impact of one's actions on the natural and built world (e.g. minimize resource and energy consumption, use of non-toxic substances, reduce waste production)." (Kollmuss and Agyeman 2002, page 240).

Deforestation implies that large amounts of $\mathrm{CO}_{2}$ are released into the atmosphere (Campbell et al. 2017) potentially contributing to climate change. Indonesia has the fourth-highest greenhouse gas emissions worldwide and has the highest loss for the primary forest, reflecting the massive pressure on land and the climate (Austin et al. 2015). Indonesia is also negatively affected by climate change. According to the 2020 report of the World Meteorological Organization (WMO), climate-related disasters (floods, droughts, and storms) have increased, and rising temperatures are leading to the loss of species and ecosystems and the occurrence of diseases, which can reduce agricultural yields and thereby, negatively affect livelihoods (Arora 2019; WMO 2020) in the long run. The increasing occurrences of droughts in South East Asia have already caused production declines of palm oil (Paterson 2015) threatening the livelihoods of farmers. 


\subsection{Research gaps}

\subsubsection{Policy interventions to adopt agricultural technologies with positive effects on the environment}

Many governments in developing countries have identified the adoption of welfare-enhancing technologies as an important goal for increasing agricultural productivity and promoting growth, improving food security, and overcoming poverty (Asfaw et al. 2012; Duflo et al. 2010). Subsidies have been used as an option to diffuse and spur adoption, especially in cases with missing information (Aker 2011; Romero et al. 2019) or market inefficiencies (Knowler and Bradshaw 2007). They have been an efficient instrument for technologies with direct benefits, where the decision to adopt is motivated by productivity increases for the adopters, such as the adoption of improved seeds (Asfaw et al. 2012), and fertilizer applications (Duflo et al. 2010). In the case of agricultural technologies with a public good character, such as native tree planting, payments for ecosystem services (PES) programs have often been implemented to increase adoption (Cole 2010; Arriagada et al. 2015). In this case, subsidies might be justified by the delayed private benefits for the adopters.

Planting native trees in homogenized landscapes has been suggested as one promising management practice to support important ecosystem functions (Koh 2008; Potvin and Gotelli 2008; Lim et al. 2015; Gérard et al. 2017) and to satisfy livelihood strategies (Koh and Wilcove 2008). However, as the profitability of oil palms is high, the protection of forests and farmland for planting native trees have high opportunity costs (Butler et al. 2009; Koh and Ghazoul 2010; Feintrenie et al. 2010a; Feintrenie et al. 2010b; Sayer et al. 2012).

Scholars have shown that for agricultural technologies where adoption decisions are mainly guided by potential productivity increases, short-term subsidies can be a suitable instrument to encourage adoption (Dupas 2014). Literature also shows that subsidies for technologies that are easy to use and that do not need maintenance do not negatively affect use over time (Dupas 2014). Yet, for agricultural technologies that benefit society at large and that imply delayed private benefits and need maintenance, such as native tree planting, only a few studies exist with regards to strategies on how to spur and disseminate adoption effectively. The studies by Jack (2013), Jack et al. (2015), and Rudolf et al. (2020) look at tree adoption through subsidies. These studies show that subsidies can increase adoption rates but they found mixed results for tree survival. In the case of native tree planting, subsidies might be associated with crowding effects regarding additional planting efforts (Köszegi and Rabin 2006; Greiner and Gregg 2011; Rode et al. 2015; Kremer and Willis 2016; Omotilewa et al. 2019) and low tree survival due to low utilities of the adopters. Hence, evidence is missing on how to effectively spur adoption, tree survival, and additional planting efforts. 


\subsubsection{Environmental concern and pro-environmental behavior in an oil palm cultivating hotspot}

The continuing oil palm boom in Indonesia has entailed many negative environmental effects (Koh and Wilcove 2008; Obidzinski et al. 2012; Lee et al. 2014). The effects on the environment include water pollution from agrochemical use and air pollution from fires when land is cleared for new oil palm plantations. These negative repercussions affect both rural and urban populations who may or may not be involved in the oil palm sector (Varkkey 2013).

Literature shows that negative environmental effects influence individuals' environmental concern and their pro-environmental behavior (Vorkinn and Riese 2001; Kollmuss and Agyeman 2002; Bolderdjik et al. 2013; Rode et al. 2015). As Meinhold and Malus (2005) show, environmental concern and pro-environmental behavior can form the decisions about the (sustainable) use of natural resources. This makes it highly relevant for policymakers to better understand the environmental concern and pro-environmental behavior of local populations, and to inform the development of more targeted policy and outreach measures to support sustainable land-use transformations. There exists an extensive strand of literature on environmental concern and pro-environmental behavior in industrialized nations focusing on rural-urban differences (Berenguer et al. 2005; Saphores et al. 2006; Huddart-Kennedy et al. 2009; Yao 2015). These studies show that urban and rural people differ with regard to their environmental concern and pro-environmental behavior. However, the studies find mixed results of who is more concerned and who engages more in pro-environmental behavior. To date, research on environmental concern and pro-environmental behavior for societies living in an environment characterized by rapid land-use change in the Global South is scarce (Chileshe and Sampa Moonga 2019).

\subsubsection{Climate change perceptions among small-scale oil palm farmers}

The pressure on agricultural land has augmented worldwide due to a growing population and an increasing demand for agricultural products (Lasco et al. 2011; Arora 2019). Therefore, agriculture has actively contributed to climate change, e.g. through the release of great amounts of $\mathrm{CO}_{2}$ into the atmosphere (Arora 2019). In return, agriculture has also been negatively affected by climate change through an increase in climate-related disasters and rising temperatures (Arora 2019; Peace 2020; WMO 2020).

In this context, the oil palm boom in Indonesia is an outstanding example of the interactions between agriculture and the environment. While climate change negatively affects oil palm cultivation through 
an increase in frequency and severity of extreme weather events and increasing temperatures leading to crop diseases, the oil palm boom also actively contributes to it. Through the loss of forest areas to establish new oil palm plantations large amounts of $\mathrm{CO}_{2}$ have been released into the atmosphere (Campbell et al. 2017). The major part of global warming experienced today and throughout the next 30 years is based on emissions that have already been released into the atmosphere (Paterson et al. 2013). Therefore, the degree of future global warming highly depends on the emissions of today and the near future (Stern 2007; Paterson et al. 2013). Hence, suitable adaptation strategies have to become a central strategy today to slow down and decrease the implications of climate change for agriculture and vice versa in the long run.

Farmers who are aware of climate change and feel personally affected by it might be more likely to adopt adaptation strategies compared to those who do not feel personally affected by it (Simelton et al. 2013). For this reason, it is important to better understand farmers' climate change perceptions which can be considered the first step towards the adoption of adaptation strategies. Studies overall show that individuals are aware of climate change (Bohensky et al. 2013; Dhanya and Ramachandran 2015; Mulenga et al. 2017; Ullah et al. 2019) but with varying results between different countries (Lee et al. 2015). Studies also show that climate change perceptions vary with respective sociodemographics such as age, education, and wealth (Simelton et al. 2013; Muttarak and Lutz 2014; Lee et al. 2015; Singh et al. 2017; Poortinga et al. 2019). Overall, a higher wealth, a younger age, and a better education are positively correlated with climate change awareness. Yet, evidence for climate change perceptions among small-scale oil palm farmers in a setting of rapid land-use transformation remains limited.

\subsection{Research objectives}

This dissertation addresses the aforementioned research gaps with three research objectives. The first objective is to assess the adoption decisions of an agricultural technology that generates positive environmental effects among small-scale oil palm farmers to support sustainable oil palm cultivation. The first of the three essays presented in this dissertation analyzes the adoption, tree survival, and additional planting efforts of native tree planting among oil palm smallholders. The second research objective of this dissertation is to examine the environmental concern and pro-environmental behavior among the local population in a setting characterized by a rapid land-use transformation in the Global South. For this, the second essay explores environmental concern and pro-environmental behavior in a setting where the society is lives in an oil palm cultivating hotspot. The third objective is to understand climate change perceptions among small-scale oil palm farmers living in an environment 
where land use is changing rapidly. The third essay explores determinants that are associated with climate change awareness and perceived affectedness among small-scale oil palm farmers. In the following, I will present the respective research questions for each of the three essays presented in this dissertation.

The first essay looks at how to encourage adoption, tree survival, and additional investments in native tree planting through two different policy interventions. It has three research questions:

(1) Does a subsidy for native tree seedlings have a positive effect on the adoption decision and the number of trees planted compared to an auction mechanism where money has to be paid for native tree seedlings?

(2) Does a subsidy for native tree seedlings lead to a higher tree survival in comparison to an auction mechanism?

(3) Does a subsidy for native tree seedlings create higher additional planting efforts compared to an auction mechanism?

To address these research questions we implemented two policy interventions in Jambi, Sumatra, Indonesia, with a total of 408 independent oil palm farmers. Negative binomial regressions and costeffectiveness analyses were applied to answer the research questions.

The second essay of this dissertation examines environmental concern and pro-environmental behavior in the Global South where people live in an oil palm cultivating hotspot and in a setting characterized by a rapid land-use transformation. A special focus is on rural-urban differences. The second essay answers the following research questions:

(4) What are the drivers of environmental concern in a setting characterized by rapid land use transformation, particularly focusing on rural-urban differences in the Global South?

(5) What are the links between the place of residence, environmental concern, and proenvironmental behavior in this setting?

For this essay, we collected different measures for environmental concern and implemented a donation game as a means to measure pro-environmental behavior. We interviewed a total of 757 individuals, 408 rural residents who are all oil palm farmers, and 349 urban residents from the capital of Jambi Province, Jambi City. We analyzed the data using ordinary least squares (OLS) regressions for the environmental concern measures and OLS regressions with inverse hyperbolic sine transformation (IHS) of the outcome variable for pro-environmental behavior.

The third essay of this dissertation looks at the climate change perceptions of small-scale oil palm farmers in a setting of rapid land-use transformation and answers the following research question: 
(6) What are the determinants associated with climate change perceptions of small-scale oil palm farmers?

Our analysis used information obtained through interviews with 408 small-scale oil palm farmers. The data was then analyzed using multinomial logit estimations.

\subsection{Study area and data}

This research was conducted under the auspices of the Collaborative Research Center (CRC) 990: Ecological and Socioeconomic Functions of Tropical Lowland Rainforest Transformation System (EFForTS) implemented in Jambi, Sumatra, Indonesia. EFForTS is funded by the Deutsche Forschungsgemeinschaft (DFG, German Research Foundation) - grant number 192626868. Since the 1980s, the Indonesian government actively supported the spread of oil palm cultivation through the transmigration program as a concept for local socio-economic development where families from Java were relocated to Sumatra and other islands (Rist et al. 2010; Gatto et al. 2015; Krishna et al. 2017). The families received two to three hectares of land as well as access to extension services. After phasing out of the transmigration program, smallholders set up and managed their oil palm plots independently. Contractual bindings between small-scale oil palm farmers and companies in Jambi Province were established at the time of the transmigration program and are still common today (Gatto et al. 2015).

We conducted our research in Jambi Province on the island of Sumatra, Indonesia. Sumatra is a hotspot for oil palm expansion as well as for biodiversity. In Jambi Province, about 75 percent of the land cultivated with oil palms is managed by smallholder oil palm farmers (BPS-Statistics Indonesia 2019). We collected our data in the lowland region of Jambi Province, as can be seen in the left-hand photo of figure 1. We interviewed oil palm farmers in the three oil-palm growing districts of Muaro Jambi, Batanghari, and Sarolangun. In these three districts, the area under oil palm cultivation has increased the most between 1995 and 2011 (Euler et al. 2016b). We also interviewed citizens in Jambi City. 


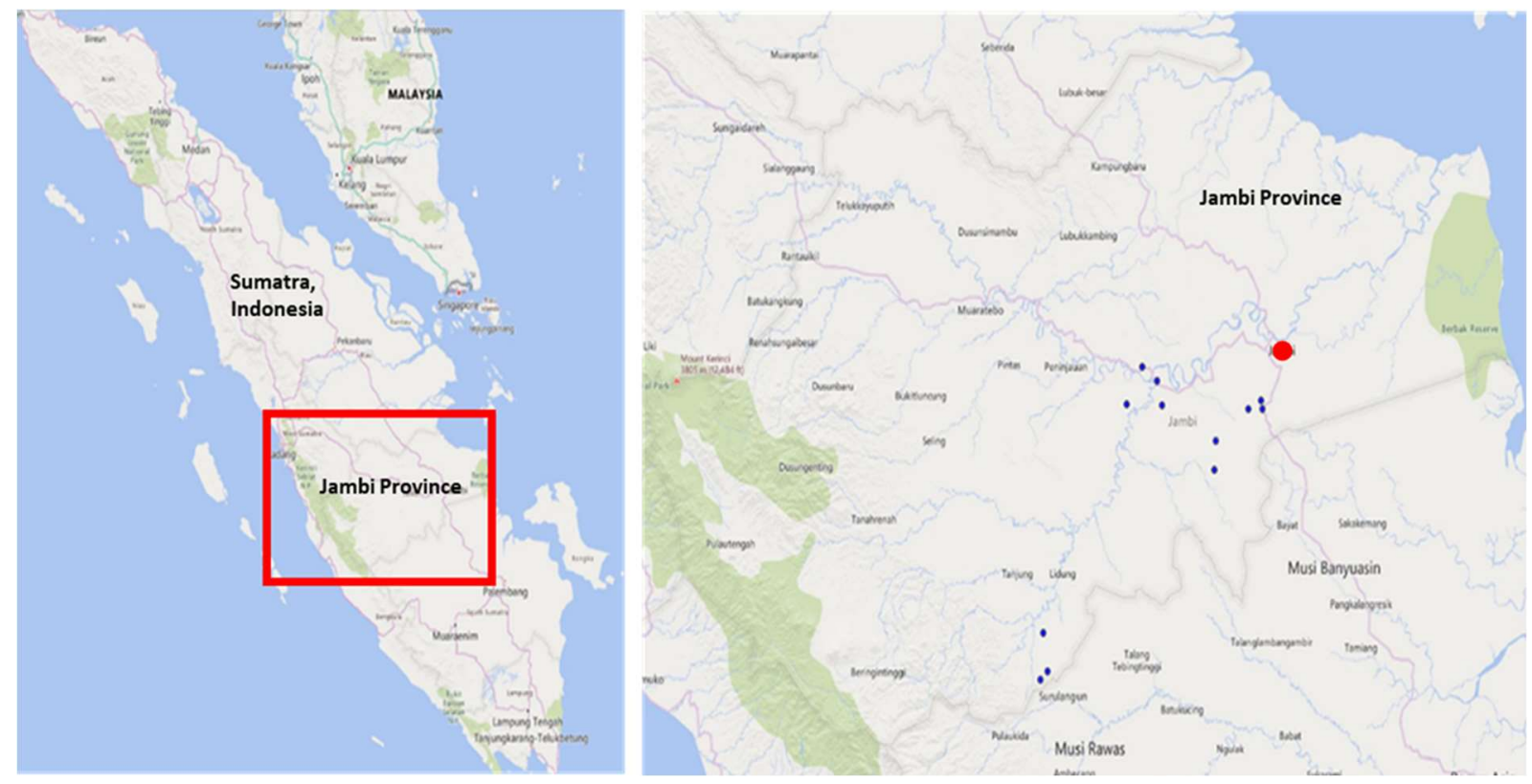

Figure 1.1: Research area: Jambi, Sumatra, Indonesia

The data used in this dissertation build on three rounds of data collection. Between April and May 2019, we visited Jambi for a pre-testing of the overall questionnaire and the auction mechanism with oil palm smallholders. We conducted focus group discussions with oil palm farmers to identify the tree seedlings that farmers prefer for potential planting on their farms and in their oil palm plantations.

The first main data collection took place between July and September 2019 and was split into two parts. The first part consisted of the interviews with the oil palm farmers in the villages. For this part of the data collection, we selected a total of 12 transmigrant and local villages in Muaro Jambi, Batanghari, and Sarolangun to reflect the actual composition of farmers in Jambi. The blue dots in figure 1.1 (right photo) reflect the villages that we visited. In ten villages we randomly selected 40 independent oil palm farmers and interviewed them between July and August 2019. In the two remaining villages, we interviewed 20 farmers due to technical problems. We selected another two villages and further interviewed 24 oil palm farmers who were randomly selected. This resulted in a total sample of 408 oil palm farmers.

The second part of the data collection included interviews with citizens in Jambi City between August and September 2019. We randomly selected six out of 11 districts in Jambi City (see the orange dot on the right photo in figure 1.1). For each of the selected districts, we randomly selected 10 sub-districts, in which we randomly selected between 32 and 37 households depending on the size of the subdistrict. Hence, for the urban setting, we could conduct interviews with a total of 349 respondents. The total sample consists of 757 respondents.

Six months after the first main data collection, we went back to Jambi between January and February 2020 to conduct the second main data collection. For this, we reinterviewed all oil palm farmers that 
we visited six months before. The aim was to understand what the farmers had done with the tree seedlings they received from us, whether and where they planted them, and whether they obtained more tree seedlings. During this visit, we interviewed 397 out of the original 408 oil palm farmers which leaves us with an attrition rate of 2.7 percent (five attritors were from the first treatment and six from the second treatment). As the attrition rates between the two treatments did not significantly differ, the indication for having an attrition bias seems to be rather small (Dumville et al. 2006).

\subsection{Outline of the dissertation}

This dissertation has the following structure: Section 2 presents the first of the three essays, analyzing the adoption, tree survival, and additional planting efforts for native tree planting among oil palm smallholders. In section 3, the second essay is presented. It looks at environmental concern and proenvironmental behavior among rural and urban residents in a setting characterized by a rapid land-use transformation in the Global South. Section 4 focuses on the third essay that presents results on the determinants that are associated with climate change perceptions of small-scale oil palm farmers. The final section, section 5 presents the main findings of this dissertation, outlines suitable policy recommendations, shows some limitations of this research, and offers scope for future research. 


\title{
2 How to promote agricultural technologies that generate positive environmental effects?
}

\section{Evidence on tree planting in Indonesia ${ }^{1}$}

\begin{abstract}
Agricultural technologies frequently have been introduced via subsidies to accelerate diffusion and spur adoption in the presence of market inefficiencies or missing information. Yet, for agricultural technologies that mainly generate positive environmental effects, it is not clear how to encourage adoption, maintenance, and additional investments most effectively. This study addresses this gap by comparing two policy interventions to foster tree planting in an oil palm hotspot in Indonesia. In the first treatment, oil palm farmers receive information about native tree planting and three different native tree seedlings for free (subsidy treatment). In the second treatment, oil palm farmers receive the same information and the opportunity to buy three different native tree seedlings through an auction (price treatment). Results from negative binomial regressions reveal that a subsidy leads to higher tree adoption and survival rates, but tends to lower engagement in additional planting efforts compared to the price treatment. Finally, we look at the willingness to pay for native tree seedlings of farmers in the price treatment and compare cost-effectiveness measures between the two treatments. We find that when taking additional planting efforts into account, the price treatment is more costeffective, although this is driven by few farmers obtaining large numbers of tree seedlings.
\end{abstract}

Keywords: Technology adoption, policy analysis, auction, subsidy, negative binomial estimation

\footnotetext{
${ }^{1}$ This chapter is under review at Ecological Economics and co-authored by Bambang Irawan (BI) and Meike Wollni (MW). Karina Brenneis (KB) conceptualized the research idea, designed the experiment, collected, analyzed, interpreted the data, and wrote the manuscript. BI helped with the implementation of the research in Indonesia and assisted in revising the manuscript. MW commented at different stages of the research and helped with the revision of the manuscript.
}

Funding: This study was funded by the Deutsche Forschungsgemeinschaft (DFG, German Research Foundation) - grant number 192626868 - in the framework of the collaborative German-Indonesian research project CRC 990. 


\subsection{Introduction}

In many developing countries, governments have identified the adoption of welfare-enhancing technologies as an important goal for increasing agricultural productivity and promoting growth, improving food security, and overcoming poverty (Asfaw et al. 2012; Duflo et al. 2010). To overcome barriers such as market inefficiencies (Knowler and Bradshaw 2007) or missing information (Aker 2011; Romero et al. 2019) subsidies have been used as one way to accelerate diffusion and spur adoption. Yet, there has been a debate in the literature on whether technology promotion through subsidies is an effective means and sustainable in the long run. This becomes especially relevant when it comes to agricultural technologies that benefit society at large, with only delayed private benefits of income and production diversification for adopters. Many studies that look into promoting agricultural technologies that are socially desirable, such as native tree planting and similar technologies, focus on existing payment for ecosystem services (PES) programs that provide subsidies to individuals for adopting the specific practice (Cole 2010; Arriagada et al. 2015). Due to the delay of private benefits, this might be adequate. However, scholars have raised concerns about subsidies in this context: A subsidy might reduce the use and/or maintenance of the technology (Dupas 2014), adopters with intrinsic motivations might be crowded out (Rode 2015) and future investments of adopters might be delayed (Kremer and Willis 2016) or negatively affected altogether due to price anchoring (Köszegi and Rabin 2006; Omotilewa et al. 2019).

According to Aker (2011) and Romero et al. (2019), information provision can successfully promote the adoption of agricultural technologies in developing nations. However, respective studies mainly focus on technologies where the decision to adopt is motivated by productivity increases for the adopters, like the adoption of enhanced management practices (Van Campenhout 2019), improved seeds (Asfaw et al. 2012), and fertilizer applications (Duflo et al. 2010). Yet, for agricultural technologies that mainly aim to generate positive environmental effects, such as native tree planting, information provision alone may not be sufficient to motivate adoption. Related research on health products that benefit society at large shows that adoption rates tend to be low in the absence of subsidies, which is likely due to high price elasticities of demand (Cohen and Dupas 2010; Bensch and Peters 2017; Berry et al. 2020; Ashraf et al. 2010). Research on different policy options to promote native tree planting so far is scarce; notable exceptions are Jack (2013), Jack et al. (2015), and Rudolf et al. (2020), providing evidence that subsidies can increase the adoption of native tree planting.

Even if initial adoption is higher under subsidies, trees can only generate positive externalities if they survive in the medium to long term, which requires maintenance. In the case of easy-to-use technologies that do not require maintenance, previous literature has shown that subsidies are not associated with a decrease in use over time (Dupas 2014). The few studies that have looked at tree 
survival in this context, have compared different subsidy measures and found mixed results on survival (Jack 2013; Jack et al. 2015; Rudolf et al. 2020). In some cases, (short-term) subsidies might even lead to a long-term boost in investments. This is more likely in the case of technologies such as cooking stoves and water filters because adopters have ample time to experience the positive benefits before they need to invest in the renewal of the technology (Dupas 2014). Yet, for technologies such as native tree planting, subsidies may not necessarily encourage further investments into tree planting, as the benefits are only experienced after many years, and thus may be associated with crowding effects (Köszegi and Rabin 2006; Greiner and Gregg 2011; Rode et al. 2015; Kremer and Willis 2016; Omotilewa et al. 2019).

This paper investigates the effects of two policy instruments on the adoption of native tree planting, as a maintenance-intense agricultural technology with positive environmental effects. To address our question, we implemented two treatments with small-scale oil palm farmers in Jambi, Sumatra, Indonesia. In one treatment oil palm farmers received information about native tree planting and three native tree seedlings for free (subsidy treatment). In a second treatment, oil palm farmers received the same information about native tree planting and had the opportunity to buy native tree seedlings through an auction (price treatment). We compare the two treatments concerning the number of native trees planted and the number of trees surviving after several months. We also test for crowding effects by looking at additional planting efforts and compare the cost-effectiveness of the two treatments to derive policy recommendations. Finally, we analyze farmers' bids in the price treatment to investigate the relationship between farmers' willingness to pay (WTP) for tree seedlings and their tree planting behavior.

The rest of the paper is organized as follows: Section 2 describes the ongoing land use transformation in Jambi, Indonesia, and develops our conceptual framework. Section 3 introduces the research design, describes the treatments and the econometric framework. Section 4 presents the results, which are further discussed in section 5 . Section 5 also concludes.

\subsection{Study context and conceptual framework}

\subsubsection{Study context}

Our research was implemented in Jambi Province on the island of Sumatra, Indonesia. In the last decades, Indonesia has experienced a rapid expansion of oil palm plantations, advancing to the largest exporter of palm oil worldwide (Rist et al. 2010; Gatto et al. 2015). Between 2000 and 2018, the oil palm area has increased from four million to twelve million hectares (BPS-Statistics Indonesia 2019), 
Chapter 2: How to promote agricultural technologies that generate positive environmental effects? Evidence on tree planting in Indonesia

implying large-scale land-use transitions (Villamor et al. 2015). The Province of Jambi on the island of Sumatra is a hotspot for oil palm expansion: the area under oil palm cultivation increased from 150,000 hectares in 1996 to 770,000 hectares in 2018 (Gatto et al. 2015, BPS-Statistics Indonesia 2019). Most of the oil palm plantations in Jambi have been established on former forest land (Koh and Wilcove 2008; Schwarze et al. 2015) as well as on land previously used for rubber and food crops (Schwarze et al. 2015).

Besides large companies and the Indonesian government investing in oil palm estates, 75 percent of the oil palm area in Jambi Province is managed by small-scale farmers (BPS-Statistics Indonesia 2019). The Indonesian government has actively supported the spread of oil palm cultivation through a transmigration program that was set up in the 1980 s as a concept for local socio-economic development. Under this program, families from Java were relocated to Sumatra and other islands (Rist et al. 2010; Gatto et al. 2015; Krishna et al. 2017) and received two to three hectares of land for cash crop cultivation. Since the phasing-out of the transmigration program, land conversion towards oil palm is mainly driven by independent smallholders (Gatto et al. 2015).

Previous literature has documented the positive economic effects (Rist et al. 2010; Austin et al. 2017) and the related improvements in rural livelihoods (Obidzinski et al. 2012) associated with the oil palm boom in Indonesia. On the other hand, the expansion of oil palm monocultures has raised social and environmental concerns (Koh and Wilcove 2008; Obidzinski et al. 2012; Lee et al. 2014). Sumatra is considered a biodiversity hotspot, where the rapid land-use transformation towards oil palm has led to a homogenization of the landscape, unprecedented forest loss, and decreases in biodiversity and water availability (Feintrenie and Levang 2009; Gibson et al. 2011; Merten et al. 2016; Austin et al. 2017; Dislich et al. 2017). Furthermore, oil palm expansion has been linked to decreases in soil carbon, and to increases in greenhouse gas emissions (Fargione et al. 2008; Van Straaten et al. 2015).

To restore important ecosystem functions in homogenized landscapes, native tree planting has been suggested as a promising management practice (Koh 2008; Potvin and Gotelli 2008; Lim et al. 2015; Gérard et al. 2017). Native tree planting increases habitat complexity and landscape heterogeneity (Atiqah et al. 2019) and thereby preserves plant and bird species (Feintrenie and Levang 2009; Cole et al. 2010; Atiqah et al. 2019) and even some of the functions of a natural forest (Teuscher et al. 2016). If planted as clusters, trees can act as areas of recovery (Potvin and Gotelli 2008; Teuscher et al. 2016). Cole et al. (2010) found that even small tree islands established in degraded tropical landscapes can increase bird activity and pollination through seed rains. Hence, farms could be used as biodiversity reservoirs (Acharya 2006). 
Oil palm farmers in Jambi Province already experience negative consequences of widespread landscape homogenization, e.g. through income fluctuations (Gérard et al. 2017; Slingerland et al. 2019), decreases in water availability (Merten et al. 2016), or polluting haze resulting from massive fires that are used to clear land for oil palm cultivation (Varkkey 2013). Planting native trees that provide fruit or timber could potentially allow farmers to diversify their income sources and reduce their exposure to income fluctuations (Slingerland et al. 2019). However, the profitability of oil palms is high, and accordingly, planting native trees on farmland is associated with high opportunity costs (Butler et al. 2009; Koh and Ghazoul 2010; Feintrenie et al. 2010a; Feintrenie et al. 2010b; Sayer et al. 2012). If native trees are integrated into oil palm plantations, this may entail negative economic effects due to competition for nutrients, light, and water between native trees and oil palms (Koh and Wilcove 2008). Despite these potential negative yield effects, there is evidence that oil palm farmers sometimes prefer mixed cropping systems, including trees in their oil palm plantations, for diversification and stabilization of income (Rist et al. 2010; Teuscher et al. 2015; Slingerland et al. 2019). Thus, while planting native trees in monocultural landscapes is socially desirable due to positive environmental effects, the private benefits are less clear and may materialize only delayed.

\subsubsection{Conceptual framework}

In this study, we test two policy interventions to promote the adoption of native tree planting in an oil-palm-dominated landscape. The subsidy treatment provides farmers with information on native tree planting and three tree seedlings for free. The price treatment provides farmers with the same information and an opportunity to acquire three tree seedlings by making a bid in an auction. Previous research found that generating market access for socially desirable technologies that require maintenance resulted in low adoption levels due to demand being highly price-elastic (Cohen and Dupas 2010; Bensch and Peters 2017). On the other hand, Jack (2013) and Rudolf et al. (2020) have shown that subsidies on trees are associated with significant increases in adoption rates. Accordingly, we expect that in the subsidy treatment, farmers will plant most of the tree seedlings received for free. In contrast, in the price treatment, we expect that farmers' WTP is often too low to acquire the tree seedlings, resulting in lower adoption rates compared to the subsidy treatment. We formulate our first hypothesis as follows:

H1: The subsidy treatment, where farmers receive tree seedlings for free, has a positive effect on the adoption decision and the number of trees planted compared to the price treatment. 
For trees to survive and thus generate substantial environmental benefits, farmers need to invest in their maintenance. In this context, subsidies bear the risk that tree planting is adopted by farmers with lower utilities for native trees, who in the absence of immediate direct benefits, are not willing to invest in repeated maintenance activities after planting (Dupas 2014). In contrast, farmers making successful bids in the auction are likely to attach higher utilities to native trees and accordingly take care of the seedlings after planting. Thus, we expect tree survival rates to be lower in the subsidy treatment compared to the price treatment. Eventually, the environmental benefits generated depend on the total number of trees that survive, which is a combination of the initial rate of adoption and the tree survival rate. Thus, even if the subsidy motivates farmers to plant more trees compared to the price treatment, as hypothesized above, low survival rates are likely to reverse the picture over time. Accordingly, we formulate the following second hypothesis:

H2: Six months after the intervention, the number of surviving trees is lower in the subsidy treatment compared to the price treatment.

From a policy perspective, besides the survival of the distributed trees, spurring more widespread adoption of tree planting is also critical to achieving significant environmental effects. Thus, for a policy intervention to be effective, it is important that it does not discourage further investments into the technology. To raise interest in tree planting, we provided the same information about the benefits of native trees in both treatments. However, previous literature has shown that subsidies may negatively affect future investments due to crowding effects, e.g. price anchoring (Köszegi and Rabin 2006; Omotilewa et al. 2019) or adopters might lose motivation to stay engaged (Greiner and Gregg 2011; Rode et al. 2015). Accordingly, our third hypothesis is:

H3: The subsidy treatment has a negative effect on additional tree planting (beyond the three distributed trees) compared to the price treatment.

\subsection{Empirical framework}

\subsubsection{Sampling and data collection}

Our research was implemented in the lowland region of Jambi Province, where we conducted our interviews in the three oil palm growing districts Muaro Jambi, Batanghari, and Sarolangun. These are the three districts in Jambi Province, where the oil palm area has expanded the most between 1995 and 2011 (Euler et al. 2016). We randomly selected 12 villages, including both local villages as well as villages established under the transmigration program. Subsequently, we randomly selected between 
20 and 40 oil palm farmers per village, resulting in a total sample size of 408 farmers. Our sample includes independent oil palm farmers only. Contracts between small-scale oil palm farmers and companies that were set up during the time of the transmigration program are still common in Jambi Province today. Farmers with a contract typically have agreed to manage their oil palm plantation according to company regulations. Since this may limit their ability to make decisions regarding tree planting in their oil palm plantations, we decided to exclude them from our study. Our target to interview 40 farmers was achieved in 8 villages; in two villages we could only interview 24 farmers, and in two villages 20 farmers due to logistical problems.
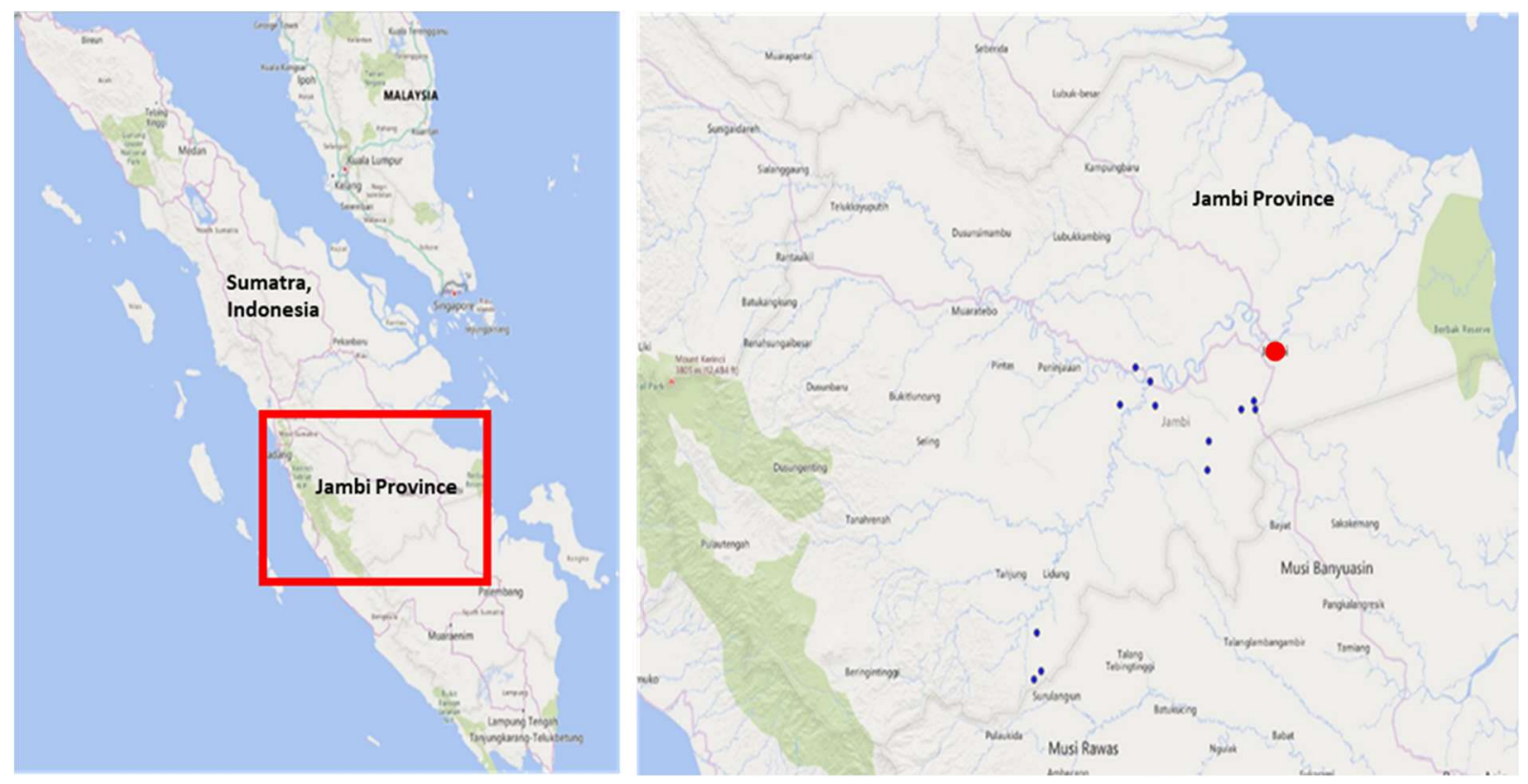

Figure 2.1: Research area: Jambi, Sumatra, Indonesia: On the left photo you can see the map of the island of Sumatra, Indonesia; On the right photo you can see Jambi Province on Sumatra, Indonesia (The blue dots mark the villages where the interviews were conducted and the orange dot marks Jambi City.)

Our total sample of 408 farmers was equally split between the two treatments. To reduce information spillovers, the randomization of the two treatments was done at the village level. Accordingly, six villages (204 farmers) were randomly assigned to the subsidy treatment and six villages (204 farmers) to the price treatment.

Data collection consisted of three steps. In April 2019, we conducted focus group meetings to identify native tree species preferred by farmers. During this field visit, we also pre-tested the questionnaire and the auction mechanism. From July to August 2019, we implemented the survey. Farmers were interviewed individually based on a structured questionnaire that incorporated the treatment. Six months after the first survey, i.e., between January and February 2020, we visited each farmer again to conduct a follow-up interview. We asked the farmers detailed questions about what they did with 
Chapter 2: How to promote agricultural technologies that generate positive environmental effects? Evidence on tree planting in Indonesia

the tree seedlings, where they planted them, and what type of maintenance they had given them². This also included a visit to the place where each farmer stated to have planted the tree seedling(s). In the follow-up survey, we were able to reach 397 of the original 408 farmers, implying an attrition rate of 2.7 percent. Out of the 11 attritors, five are from the subsidy treatment and six from the price treatment. Attrition rates are not significantly different between the two treatments $(p=0.76)$ and hence, attrition bias is unlikely to be an issue (Dumville et al. 2006) . $^{3}$

\subsubsection{Description of treatments}

In both treatments, we offered each farmer one bundle of three native tree seedlings. During focus group meetings in April 2019, four native tree species were identified that are suitable to be planted with oil palm and valued by farmers. These include three fruit trees - Durian (Durio zibethinus), Duku (Lansium domesticum), and Mangosteen (Garcinia mangostana), and one timber tree - Meranti (Shorea leprosula). The four identified species were combined in four different tree bundles (table 2.1). To assess farmers' preferences for different tree bundles, these were assigned randomly to the interviewed farmers.

\begin{tabular}{|c|c|c|}
\hline No. & Trees in the bundle & $\begin{array}{c}\text { Price for each bundle in USD and (IDR }{ }^{4} \text { ) for } \\
\text { T2 }\end{array}$ \\
\hline 1 & Meranti, Duku, Mangosteen & $\begin{array}{c}6.09^{5} \\
(86,000)\end{array}$ \\
\hline 2 & Durian, Duku, Meranti & 5.24 \\
& $(74,000)$ \\
\hline 3 & Meranti, Durian, Mangosteen & 4.95 \\
& $(70,000)$ \\
\hline 4 & Durian, Duku, Mangosteen & 6.09 \\
& & $(86,000)$ \\
\hline
\end{tabular}

Table 2.1: Description of prices for different tree bundles

Both treatments consisted of two components: an information component and the distribution of seedlings. During the first component, each farmer received information about the benefits of planting native trees on their land including in oil palm plantations. We also gave each farmer an information

\footnotetext{
${ }^{2}$ Farmers might have adapted their behavior knowing that they take part in an experiment, which is known as the Hawthorne effect (Parsons, 1974). To perform well in the study or to meet experimenter expectations, they may plant more trees than they otherwise would have. To reduce such biases to the extent possible, we did not inform farmers during the first survey that we would return six months later. ${ }^{3}$ In order to understand if attrition is random or systematic and hence, if we have to include further measures, we run an attrition probit followed by a Wald test (Fitzgerald, Gottschalk and Moffitt 1998; Moffitt et al. 1999; Outes-Leon and Dercon 2008; Baulch and Quisumbing 2011). If attrition is non-random our results of the ITT effects might be biased. The results show that we do not have significant predictors of attrition in our baseline variables (Wald test result: $p=0.5640$ ). Hence, no further measures are applied.

${ }^{4}$ The prices for each bundle consisted of the price that we had to pay for each tree seedling at the nursery in Jambi City plus an average amount per bundle of transport costs for the seedlings which consisted of fuel needed on average to reach the targeted villages, the costs for the trucks, the salary for the drivers plus per diem as well as the salary for the assistants and their per diem. The prices are shown in USD (conversion rate from June 2019) and Indonesian Rupiah (IDR).

${ }^{5}$ The prices in USD shown were converted with the conversion rate from June 2019.
} 
Chapter 2: How to promote agricultural technologies that generate positive environmental effects? Evidence on tree planting in Indonesia

booklet ${ }^{6}$ with more details on the economic and environmental benefits of native tree planting in oil palm landscapes as well as instructions on how to plant and maintain the trees. During the second component, the tree bundles were offered to the farmer, with the distribution mechanism varying depending on the treatment. In the first treatment, the subsidy treatment, each farmer was given one randomly chosen tree bundle free of charge. In the second treatment, the price treatment, farmers had the opportunity to place a bid for one randomly chosen tree bundle in an auction. Jointly with the tree seedlings, we provided contact details of a forestry expert at the University of Jambi, whom the farmers could contact in case of questions or to order more seedlings.

The auction in the price treatment was implemented using the Becker-DeGroot-Marschak (BDM) method (Becker et al. 1964). The BDM method is a single-bid auction mechanism and preference revealing (Becker et al. 1964), and hence, allows us to measure farmers' WTP for the offered tree bundle. After offering the farmer a tree bundle, we explained that the auction price varies between 0.14 USD (2,000 IDR) and the maximum price of 4.95 USD (70,000 IDR), 5.24 USD (74,000 IDR), or 6.09 USD (86,000 IDR), depending on the bundle offered to the farmer (see Table 1). Price chips were drawn from a bag and increased in steps of 2,000 IDR, to cover the full range of anticipated bids. Farmers were given time to inspect the tree seedlings and carefully consider their bid, before offering a price. Once the farmer had placed his or her bid, the auction price was randomly drawn from the bag and shown to the farmer. If the farmer's bid was equal to the auction price or higher, the farmer bought the tree bundle at the auction price. If the farmer's bid was lower than the auction price, the farmer could not buy the tree bundle.

Before auctioning the tree bundle, we explained to the farmer in detail how the process of the auction works. We then conducted practice rounds, where the farmer could offer a price for a pack of pencils to make sure the farmer understood the procedure, felt comfortable, and had enough time to ask questions. In the price treatment, we paid farmers a participation fee during the survey of either 70,000 IDR, 74,000 IDR, or 86,000 IDR, depending on the tree bundle that was assigned to them ${ }^{7}$. The money was framed as compensation for their participation in the survey and was for them to keep. We decided to make this upfront payment to overcome potential liquidity constraints and to minimize the importance of having money in cash during the interview (Jack et al. 2015).

\footnotetext{
${ }^{6}$ The manual can be found online: https://www.uni-

goettingen.de/de/document/download/2e1a3f5ebcda379d054a20381d7708f2.pdf/Material\%20of\%20the\%20information\%20campaign\% 20-\%20illustrative\%20manual.pdf

${ }^{7}$ The amount of money given to each respondent is below the daily wage of an oil palm farmer in the region (Kubitza et al. 2019).
} 


\subsubsection{Econometric framework}

We estimate the intent-to-treat (ITT) effect of the subsidy treatment on native tree planting and tree survival, in comparison to the price treatment. The model to be estimated is specified as follows:

$Y_{h i}=\beta_{0}+\beta_{1} T 1_{i}+\beta_{2} X_{h i}+\beta_{3} Y_{h i}{ }^{P R E}+\varepsilon h i$

where $Y_{h i}$ is the outcome variable, i.e., either the binary adoption decision, the number of trees planted, or the number of trees that survived for farmer $h$ in village $i . T 1_{i}$ is a dummy that equals 1 if the farmer was assigned to the subsidy treatment; $T 1_{i}$ equals 0 if the farmer was assigned to the price treatment. $X_{h i}$ is a vector of variables containing household characteristics. To reduce the variance of the treatment estimator, we estimated an ANCOVA (McKenzie 2012) by including baseline dependent variables $Y_{h i}{ }^{P R E}$, measuring the number of trees in oil palm plantations and home gardens and whether any trees were planted during the twelve months preceding the intervention. The ANCOVA estimator is preferred over the difference-in-differences estimator when autocorrelation between the baseline dependent variable and the actual dependent variable is low, which finds support in our data ${ }^{8} . \varepsilon$ hi is a random error term clustered at village level.

The binary adoption decision of planting trees is modeled using probit regressions (Long 1997). The number of trees planted and the number of trees survived represent count data and we have 52 percent and 59 percent zero-valued observations, respectively. For count data, if the variance exceeds the mean, there is overdispersion, which means that the traditional Poisson model does not produce correct standard errors for each parameter estimate (Greene 2012). Our outcome variables indicate overdispersion. To formally test for overdispersion we applied a Likelihood-ratio (LR) test following Cameron and Trivedi (1986) and Hilbe (2011). The LR test with one degree of freedom is significant, indicating that the hypothesis of no overdispersion is rejected ${ }^{9}$. Hence, we apply negative binomial regressions for the number of trees planted and the number of trees that survived. The negative binomial regression is a Poisson-Gamma mixture model (Long and Freese 2006; Hilbe 2011), which is also recommended in the case of large shares of zero-valued observations (Bellemare and Wichman 2019).

\footnotetext{
${ }^{8}$ Autocorrelation coefficient: 0.002 for the baseline dependent variable of trees planted in home gardens, oil palm, rubber and fallow land ${ }^{9}$ Number of trees planted: LR test of alpha=0: chibar $2(01)=18.11$; Prob $>=$ chibar2 $=0.000$; Number of trees survived: $L R$ test of alpha=0: chibar2(01) = 13.33; Prob >= chibar2 $=0.000$
} 


\subsection{Results}

\subsubsection{Descriptive results}

Table 2.2, panel A, presents descriptive statistics of the baseline variables of our sample. We show mean estimates for the full sample (column (1)) and the two treatments (columns (2) and (3)) as well as 16 tests for mean differences (column (4)). Most mean differences tests are statistically insignificant, except for the dummy variable trees planted in oil palm in the last 12 months and the total size of the land owned, which is larger for farmers in the price treatment. Despite these significant differences in average land size, the average size of the oil palm area does not differ between the two treatments. Also, the baseline dependent variable on the number of trees in oil palm plantations and home gardens does not significantly differ between the treatments. Given that some imbalance can occur by chance, our randomization can be considered successful. In the econometric estimation, we include the imbalanced variables to reduce potential confounding effects.

Panel B of table 2.2 presents descriptive statistics of tree planting outcomes from the follow-up survey. From the $978^{10}$ trees distributed in our treatments, a total of 385 trees (39.35 percent) had been planted at the time of the follow-up visit ${ }^{11}$. From these 385 trees planted, 177 tree seedlings were planted in oil palm and rubber plantations, and on fallow land, and 206 seedlings were planted in home gardens. When comparing the two treatments, significantly more trees were planted in the subsidy treatment. Besides, a significantly larger share of farmers in the subsidy treatment planted trees compared to the price treatment.

\begin{tabular}{|l|c|c|c|c|}
\hline \multirow{2}{*}{} & $(1)$ & $(2)$ & $(3)$ & $(4)$ \\
\cline { 2 - 5 } & Full sample & $\begin{array}{c}\text { Subsidy } \\
\text { treatment }\end{array}$ & $\begin{array}{c}\text { Price } \\
\text { treatment }\end{array}$ & Subsidy = Price \\
\hline Panel A & \multicolumn{3}{|c|}{ Mean estimates } & p-values \\
\hline \multicolumn{5}{|c|}{ Household head characteristics } \\
\hline Age of household head & $\begin{array}{c}50.54 \\
(11.00)\end{array}$ & $\begin{array}{c}50.54 \\
(11.08)\end{array}$ & $\begin{array}{c}50.53 \\
(10.96)\end{array}$ & 0.995 \\
\hline $\begin{array}{l}\text { Sex of household head } \\
\text { (1=female) }\end{array}$ & 0.06 & 0.07 & 0.05 & 0.32 \\
\hline $\begin{array}{l}\text { Education of household } \\
\text { head in years }\end{array}$ & $\begin{array}{c}9.53 \\
(4.28)\end{array}$ & $\begin{array}{c}9.61 \\
(4.08)\end{array}$ & $\begin{array}{c}9.45 \\
(4.49)\end{array}$ & 0.80 \\
\hline \multicolumn{5}{|c|}{ Household characteristics } \\
\hline $\begin{array}{l}\text { Distance to Jambi City (in } \\
\text { km) }\end{array}$ & $\begin{array}{c}93.57 \\
(63.03)\end{array}$ & $\begin{array}{c}89.54 \\
(65.68)\end{array}$ & $\begin{array}{c}97.60 \\
(60.17)\end{array}$ & 0.83 \\
\hline
\end{tabular}

\footnotetext{
${ }^{10}$ From the original 1.005 trees 27 trees had to be deducted for the analysis because these were received by the attritors.

${ }^{11} 21.06$ per cent of the trees received were planted in home gardens, 14.31 per cent were planted in oil palm plantations, 2.86 per cent were planted in rubber plantations, 0.92 per cent was planted in fallow land and 0.20 per cent was planted in other places that the farmer did not specify and hence, could not be included in the analysis. 4.30 per cent of the tree seedlings were given away as present, stolen or the farmer could not remember what happened with the tree seedlings. 22.90 per cent of the trees received by the farmers have not been planted yet but are still alive. 33.44 per cent of the trees given died before being planted.
} 
Chapter 2: How to promote agricultural technologies that generate positive environmental effects? Evidence on tree planting in Indonesia

\begin{tabular}{|c|c|c|c|c|}
\hline $\begin{array}{l}\text { Number of household } \\
\text { members }\end{array}$ & $\begin{array}{c}3.80 \\
(1.30)\end{array}$ & $\begin{array}{c}3.83 \\
(1.37)\end{array}$ & $\begin{array}{c}3.76 \\
(1.24)\end{array}$ & 0.69 \\
\hline Asset index ${ }^{2}$ & $\begin{array}{c}1.83 e-11 \\
(0.62)\end{array}$ & $\begin{array}{l}-0.04 \\
(0.63)\end{array}$ & $\begin{array}{c}0.04 \\
(0.61)\end{array}$ & 0.39 \\
\hline $\begin{array}{l}\text { Transmigration program } \\
\text { (1/0) (farm level) }\end{array}$ & 0.23 & 0.25 & 0.21 & 0.80 \\
\hline $\begin{array}{l}\text { Savings account at a } \\
\text { bank }(1 / 0)\end{array}$ & 0.78 & 0.75 & 0.81 & 0.44 \\
\hline \multicolumn{5}{|c|}{ Land characteristics } \\
\hline Land owned (in ha) & $\begin{array}{c}7.02 \\
(7.90)\end{array}$ & $\begin{array}{c}5.69 \\
(4.93)\end{array}$ & $\begin{array}{c}8.35 \\
(9.86)\end{array}$ & $0.04^{* *}$ \\
\hline Hectares of oil palms & $\begin{array}{c}4.37 \\
(4.43)\end{array}$ & $\begin{array}{c}4.05 \\
(4.09) \\
\end{array}$ & $\begin{array}{c}4.69 \\
(4.74)\end{array}$ & 0.44 \\
\hline Home garden (1/0) & 0.93 & 0.95 & 0.91 & 0.47 \\
\hline $\begin{array}{l}\text { Distance nearest oil palm } \\
\text { plot to the house (in km) }\end{array}$ & $\begin{array}{c}3.39 \\
(8.30)\end{array}$ & $\begin{array}{c}2.49 \\
(5.73)\end{array}$ & $\begin{array}{c}4.29 \\
(10.18)\end{array}$ & 0.32 \\
\hline $\begin{array}{l}\text { Distance nearest oil palm } \\
\text { plot to next market (in } \\
\mathrm{km} \text { ) }\end{array}$ & $\begin{array}{l}7.46^{1} \\
(6.32)\end{array}$ & $\begin{array}{c}7.11^{1} \\
(5.21)\end{array}$ & $\begin{array}{c}7.81 \\
(7.26)\end{array}$ & 0.67 \\
\hline \multicolumn{5}{|c|}{ Tree seedlings (baseline) } \\
\hline $\begin{array}{l}\text { Seedlings expensive } \\
(1 / 0)\end{array}$ & 0.77 & 0.79 & 0.75 & 0.81 \\
\hline $\begin{array}{l}\text { Number of trees in oil } \\
\text { palm plantations and } \\
\text { home garden per ha }\end{array}$ & $\begin{array}{l}3.40 \\
(7.45)\end{array}$ & $\begin{array}{c}3.21 \\
(8.79)\end{array}$ & $\begin{array}{c}3.59 \\
(5.82)\end{array}$ & 0.77 \\
\hline $\begin{array}{l}\text { Trees planted in oil palm } \\
\text { in the last } 12 \text { months } \\
(1 / 0)\end{array}$ & 0.29 & 0.25 & 0.33 & $0.02 * *$ \\
\hline $\mathrm{N}$ (baseline) & 408 & 204 & 204 & \\
\hline \multicolumn{5}{|l|}{ Panel B } \\
\hline \multicolumn{5}{|c|}{ Tree planting outcomes } \\
\hline $\begin{array}{l}\text { Share of respondents } \\
\text { that planted tree } \\
\text { seedlings in home } \\
\text { gardens, oil palm, } \\
\text { rubber, and fallow land }\end{array}$ & $\begin{array}{c}0.48 \\
(0.50)\end{array}$ & $\begin{array}{c}0.55 \\
(0.50)\end{array}$ & $\begin{array}{c}0.40 \\
(0.49)\end{array}$ & $0.00 * * *$ \\
\hline $\begin{array}{l}\text { Number of tree } \\
\text { seedlings planted in } \\
\text { home gardens, oil palm, } \\
\text { rubber, and fallow land }\end{array}$ & $\begin{array}{c}0.97 \\
(1.16)\end{array}$ & $\begin{array}{c}1.15 \\
(1.18)\end{array}$ & $\begin{array}{c}0.80 \\
(1.12)\end{array}$ & $0.00 * * *$ \\
\hline $\begin{array}{l}\text { Number of tree } \\
\text { seedlings planted in oil } \\
\text { palm, rubber and fallow } \\
\text { land }\end{array}$ & $\begin{array}{l}0.45 \\
(0.95)\end{array}$ & $\begin{array}{c}0.57 \\
(1.04)\end{array}$ & $\begin{array}{c}0.32 \\
(0.83)\end{array}$ & $0.08 *$ \\
\hline$N$ (follow-up) & 397 & 199 & 198 & \\
\hline \multicolumn{5}{|c|}{$\begin{array}{l}\text { Columns (1) to (3) show mean estimates with the respective standard deviations in parentheses. Column (4) } \\
\text { shows p-values for mean difference tests that were conducted with linear regression models (negative } \\
\text { binomial models in case of the tree planting outcome variables) with standard errors clustered at the village } \\
\text { level. }\end{array}$} \\
\hline
\end{tabular}


Chapter 2: How to promote agricultural technologies that generate positive environmental effects? Evidence on tree planting in Indonesia

${ }^{*} p<0.1,{ }^{* *} p<0.05,{ }^{* * *} p<0.01$
$1: 3$ missing observations
2: The asset index was constructed with a factor analysis. The following assets (dummy variables) are
included: trailer cart, irrigation pipe, stereo system, computer, washing machine, fan, car or truck, and radio.

Table 2.2: Descriptive statistics

\subsubsection{Adoption and tree survival}

Table 2.3 shows the ITT effects on tree planting outcomes. Columns (1) and (2) show the effects on the adoption decision with and without control variables. Columns (2) and (3) show the effects on the number of trees planted ${ }^{12}$ with and without control variables. We find that being in the subsidy treatment increases the probability of planting trees by 17 percentage points, compared to farmers in the price treatment (column (2)). Overall, farmers in the subsidy treatment planted on average 0.46 trees more than farmers in the price treatment (column (4)). These results support our first hypothesis $(\mathrm{H} 1)$ that the subsidy treatment has a positive effect on tree planting decisions.

\begin{tabular}{|c|c|c|c|c|c|c|}
\hline $\begin{array}{l}\text { Number of trees } \\
\text { planted in home } \\
\text { gardens, oil palm, } \\
\text { rubber, and } \\
\text { fallow land }\end{array}$ & $\begin{array}{l}\text { Adoption } \\
\text { decision }\end{array}$ & $\begin{array}{l}\text { Adoption } \\
\text { decision }\end{array}$ & $\begin{array}{l}\text { Number of } \\
\text { trees planted }\end{array}$ & $\begin{array}{l}\text { Number of } \\
\text { trees planted }\end{array}$ & $\begin{array}{l}\text { Number of trees } \\
\text { that survived }\end{array}$ & $\begin{array}{l}\text { Number of trees } \\
\text { that survived }\end{array}$ \\
\hline & (1) & (2) & (3) & (4) & (5) & (6) \\
\hline $\begin{array}{l}\text { Subsidy } \\
\text { treatment }\end{array}$ & $\begin{array}{c}0.15^{* * *} \\
(0.05)\end{array}$ & $\begin{array}{c}0.17^{* * *} \\
(0.05) \\
\end{array}$ & $\begin{array}{c}0.36^{* * *} \\
(0.12) \\
\end{array}$ & $\begin{array}{c}0.46^{* * *} \\
(0.13)\end{array}$ & $\begin{array}{c}0.25^{* * *} \\
(0.08)\end{array}$ & $\begin{array}{c}0.30 * * * \\
(0.08)\end{array}$ \\
\hline $\begin{array}{l}\text { Control variables } \\
\text { included }\end{array}$ & no & yes & no & yes & no & yes \\
\hline $\mathrm{N}$ & 397 & 397 & 397 & 397 & 397 & 397 \\
\hline $\begin{array}{l}\text { Column (1) shows a } \\
\text { shows average mar } \\
\text { for the number of tr } \\
\text { trees planted withol } \\
\text { control variables fro } \\
\text { a negative binomial } \\
\text { from a negative binc } \\
\text { Besides the control } \\
\text { term. } \\
\text { Control variables inc } \\
\text { planted trees in his/ } \\
\text { from the nearest oil } \\
\text { Standard errors clus } \\
{ }^{*} p<0.1,{ }^{* *} p<0.05 \text {, } \\
\text { The full model for th } \\
\text { the appendix (table } \\
\text { The full model for th } \\
\text { can be found in the }\end{array}$ & $\begin{array}{l}\text { age margina } \\
\text { al effects }(A \\
\text { s planted wit } \\
\text { control varia } \\
\text { a negative } b \\
\text { odel without } \\
\text { ial model wit } \\
\text { iables, a pre- } \\
\text { de age, educc } \\
\text { oil palm pla } \\
\text { Im plantatio } \\
\text { ed at village } \\
p<0.01 \\
\text { results for tr } \\
1) \text {. } \\
\text { esults for tre }\end{array}$ & $\begin{array}{l}\text { cts (AME) fol } \\
\text { or the adopt } \\
\text { control varic } \\
\text { rom a negat } \\
\text { ial model; co } \\
\text { rol variables } \\
\text { control varic } \\
\text { ment depen } \\
\text { whether the } \\
\text { on in the last } \\
\text { he house of } \\
\text { in parenthes } \\
\text { edlings that } \\
\text { dlings that }\end{array}$ & $\begin{array}{l}\text { adoption decis } \\
\text { decision with c } \\
\text { from a negati } \\
\text { inomial model, } \\
\text { (5) reports th } \\
\text { lumn (6) report } \\
\text {; } \\
\text { baseline varial } \\
\text { mer was part o, } \\
\text { months, the ba } \\
\text { armer (in km), } \\
\text { e planted in ho } \\
\text { only planted in }\end{array}$ & $\begin{array}{l}\text { n without contr } \\
\text { trol variables fr } \\
\text { binomial model } \\
\text { olumn (4) report } \\
\text { AME for the num } \\
\text { the AME for the } \\
\text { was included in } \\
\text { he transmigrati } \\
\text { line dependent } \\
d \text { three differen } \\
\text { e gardens, oil pa } \\
\text { il palm and rubt }\end{array}$ & $\begin{array}{l}\text { variables from a pro } \\
\text { n a probit model; co } \\
\text { column (4) reports A } \\
\text { AME for the number } \\
\text { er of trees planted } t \\
\text { number of trees plan } \\
\text { Il model specificatior } \\
\text { program, a dummy } \\
\text { riable, land owned (i } \\
\text { tree bundles offered; } \\
\text { n, rubber, and fallon } \\
\text { r plantations as well }\end{array}$ & $\begin{array}{l}\text { bit model; column (2) } \\
\text { umn (3) reports AME } \\
\text { UE for the number of } \\
\text { of trees planted with } \\
\text { at are still alive from } \\
\text { ed that are still alive } \\
\text { s and one interaction } \\
\text { if the farmer has } \\
\text { ha), the distance } \\
\text { land can be found in } \\
\text { as on fallow land and }\end{array}$ \\
\hline
\end{tabular}


Chapter 2: How to promote agricultural technologies that generate positive environmental effects? Evidence on tree planting in Indonesia

The full models for the number of tree seedlings that were planted and are alive can be found in the appendix (tables A2.3 and A2.4).

Table 2.3: ITT effects of trees planted and trees that are still alive for trees planted in home gardens, oil palm, rubber, and fallow land

Native tree planting practices can only contribute positive environmental effects if the trees survive in the long run. Testing our second hypothesis, we analyze ITT effects on the number of trees that survived. Results show that the subsidy treatment increases the number of trees that survived by 0.30 on average, compared to the price treatment (table 2.3 column (6)). Accordingly, our results do not support our second hypothesis $(\mathrm{H} 2)$ that the subsidy treatment will result in lower tree survival. As a robustness check, we estimate the models again taking only tree planting in oil palm, rubber plantations, and on fallow land into account (excluding tree planting in home gardens). The results are in line with the results presented here (see appendix tables A2.2 and A2.4).

\subsubsection{Additional planting efforts}

From a policy perspective, it is important to ensure that subsidies do not crowd out further investments into the promoted technology. We, therefore, look into additional planting efforts that took place during our first and second visit to the farmers. In our data, we observe that 25 farmers in the price treatment obtained a total of 674 tree seedlings on their own and planted them. In the subsidy treatment, 16 farmers obtained a total of 61 tree seedlings on their own and planted them. Table 2.4 presents results from probit and negative binomial regressions on the binary decision to obtain additional tree seedlings and the number of additional tree seedlings planted. The results show that the subsidy treatment is negatively related to additional tree planting, but the coefficients are not statistically significant. Farmers in the subsidy treatment tend to be five percentage points less likely to engage in additional tree planting efforts, and on average, plant 3.26 trees less than farmers in the price treatment. Although the effect size of 3.26 is relatively large, it is not significant. Overall, our data do not provide strong support for our third hypothesis (H3) that the subsidy is associated with crowding out investments in tree planting.

\begin{tabular}{|l|c|c|c|c|}
\hline $\begin{array}{l}\text { Additional tree seedlings } \\
\text { obtained and planted in home } \\
\text { gardens, oil palm, rubber, and } \\
\text { fallow land }\end{array}$ & $\begin{array}{c}\text { Adoption } \\
\text { decision to } \\
\text { obtain more } \\
\text { tree seedlings }\end{array}$ & $\begin{array}{c}\text { Adoption } \\
\text { decision to } \\
\text { obtain more } \\
\text { tree seedlings }\end{array}$ & $\begin{array}{c}\text { Number of trees } \\
\text { planted that were } \\
\text { obtained by } \\
\text { farmers }\end{array}$ & $\begin{array}{c}\text { Number of trees } \\
\text { planted that were } \\
\text { obtained by } \\
\text { farmers }\end{array}$ \\
\hline Subsidy treatment & $(1)$ & $(2)$ & $(3)$ & $(4)$ \\
\hline Control variables included & -0.04 & -0.03 & -4.46 & -3.26 \\
$(0.03)$ & no & yes & no & yes \\
\hline $\mathrm{N}$ & 397 & 397 & 397 & 397 \\
\hline Column (1) and shows AME for the adoption decision to obtain tree seedlings without control variables; column (2) shows \\
AME for the adoption decision to obtain tree seedlings with control variables; column (3) reports the AME for the number of
\end{tabular}


Chapter 2: How to promote agricultural technologies that generate positive environmental effects? Evidence on tree planting in Indonesia

and (4) at the $99^{\text {th }}$ percentile, the differences between subsidy and price treatments are no longer statistically significant (Appendix tables A2.7 and A2.8).

\begin{tabular}{|c|c|c|c|c|}
\hline & \multicolumn{2}{|c|}{ Without additional tree seedlings obtained } & \multicolumn{2}{|c|}{ With additional tree seedlings obtained } \\
\hline & (1) & (2) & (3) & (4) \\
\hline & $\begin{array}{c}\text { Trees planted per } \\
\text { USD spent }\end{array}$ & $\begin{array}{l}\text { Trees planted and } \\
\text { survived per USD } \\
\text { spent }\end{array}$ & $\begin{array}{l}\text { Trees planted } \\
\text { per USD spent }\end{array}$ & $\begin{array}{l}\text { Trees planted and } \\
\text { survived per USD } \\
\text { spent }\end{array}$ \\
\hline Overall & $\begin{array}{c}0.07 \\
(0.09)\end{array}$ & $\begin{array}{c}0.05 \\
(0.07)\end{array}$ & $\begin{array}{c}0.21 \\
(1.63)\end{array}$ & $\begin{array}{c}0.19 \\
(1.59)\end{array}$ \\
\hline $\begin{array}{l}\text { Subsidy } \\
\text { treatment }\end{array}$ & $\begin{array}{c}0.08 \\
(0.08)\end{array}$ & $\begin{array}{c}0.06 \\
(0.07) \\
\end{array}$ & $\begin{array}{c}0.10 \\
(0.16)\end{array}$ & $\begin{array}{c}0.07 \\
(0.09)\end{array}$ \\
\hline $\begin{array}{l}\text { Price } \\
\text { treatment }\end{array}$ & $\begin{array}{c}0.06 \\
(0.09) \\
\end{array}$ & $\begin{array}{c}0.05 \\
(0.08) \\
\end{array}$ & $\begin{array}{c}0.33 \\
(2.30) \\
\end{array}$ & $\begin{array}{c}0.31 \\
(2.25)\end{array}$ \\
\hline $\begin{array}{l}\text { Subsidy }= \\
\text { Price ( } \mathrm{p}- \\
\text { values) }\end{array}$ & 0.14 & 0.21 & $0.01 * *$ & $0.00 * * *$ \\
\hline $\mathrm{N}$ & \multicolumn{4}{|c|}{397 farmers with 199 farmers in T1 and 198 in T2 } \\
\hline \multicolumn{5}{|c|}{$\begin{array}{l}\text { The cost-effectiveness analysis was done by dividing the number of trees planted or survived per farmer by the } \\
\text { costs per capita of the intervention. As we did not have a control group, our baseline value for the number of } \\
\text { trees planted was zero. }\end{array}$} \\
\hline \multicolumn{5}{|c|}{$\begin{array}{l}\text { Differences in the cost-effectiveness between } T 1 \text { and } T 2 \text { were tested with negative binomial regression models } \\
\text { regressing the treatment variable on the respective outcome variable with standard errors clustered at village } \\
\text { level. }\end{array}$} \\
\hline \multicolumn{5}{|c|}{$\begin{array}{l}\text { Costs were transformed from IDR to USD using a conversion rate from June 2019. To reflect on the true cost } \\
\text { involved we assume that the farmers in treatment arm T2 pay for the tree seedlings by themselves. } \\
{ }^{*} p<0.1,{ }^{* *} p<0.05,{ }^{* * *} p<0.01\end{array}$} \\
\hline
\end{tabular}

Table 2.6: Results from a basic cost-effectiveness analysis for tree seedlings planted in home gardens, oil palm, rubber, and fallow land

So far, our results have shown that the subsidy treatment increases the likelihood that farmers plant the distributed trees and the average number of planted trees compared to the price treatment. In line with the higher planting intensity, the subsidy treatment also increased the average number of surviving trees compared to the price treatment. Additional planting efforts that go beyond the trees distributed through the intervention tend to be lower under the subsidy treatment, suggesting that the subsidy may crowd out further investments in tree planting. The difference in additional tree planting between the subsidy treatment and the price treatment is, however, not significant. These results are reflected in the cost-effectiveness analysis. Since the subsidy treatment is associated with a higher tree planting intensity and survival of the distributed trees, but also with higher program costs, there is no significant difference in cost-effectiveness between the two treatments. Yet, when taking additional planting efforts into account, the cost-effectiveness of the price treatment is higher 
compared to the subsidy treatment; a result that is, however, driven by a small number of farmers that engage in additional tree planting efforts.

\subsubsection{WTP for tree seedlings}

In the price treatment, farmers had the opportunity to make a price offer for a bundle of three tree seedlings and thus revealed their WTP for that specific tree bundle. The frequency distribution of farmers' WTP is shown in figure 2.2.

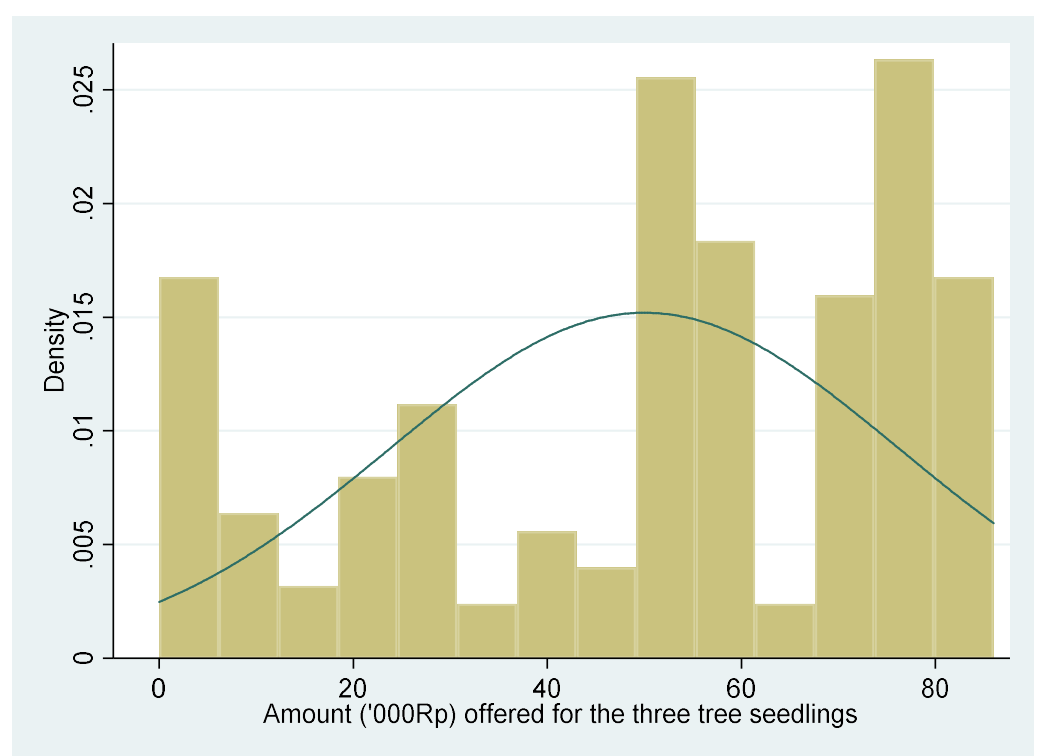

Figure 2.2: Histogram for the WTP of farmers in the price treatment

On average, farmers offered a price of 50.010 IDR (3,54 USD) for the bundle of three seedlings. A higher WTP for tree seedlings is expected to be associated with a higher valuation of native trees and thus more effort placed on planting and maintaining the trees. Focusing only on the sub-sample of the price treatment, we analyze the association between the price offered in the auction mechanism (WTP) and the number of trees planted and surviving as well as the additional tree planting effort by the farmers. The results show that farmers' WTP is positively and significantly associated with the number of trees planted and the number of surviving trees (table 2.7). When taking additional trees obtained by the farmer into account, the association between WTP and tree planting is positive, but not significant. The reason for this weak correlation between the WTP in the auction and further investments in tree planting activities may be related to farmers' lack of access to seed material, e.g., due to high prices of tree seedlings or limited market access in the villages. This finds support in our data. The average market price of a tree seedling in the villages, as indicated by farmers in the price treatment, is 65.815 IDR $\left(4,66\right.$ USD $\left.{ }^{13}\right)$, which is substantially higher than the WTP for a bundle of three tree seedlings in the

\footnotetext{
${ }^{13}$ The prices in USD shown were converted with the conversion rate from June 2019.
} 
Chapter 2: How to promote agricultural technologies that generate positive environmental effects? Evidence on tree planting in Indonesia

auction. Furthermore, around 79 percent of the farmers in the price treatment stated that it is difficult to get access to tree seedlings in their village.

\begin{tabular}{|c|c|c|c|}
\hline & \multicolumn{3}{|c|}{ Home gardens, oil palm and rubber plantations, and fallow land } \\
\hline & $\begin{array}{c}\text { Number of trees } \\
\text { planted ( } 3 \text { tree } \\
\text { seedlings) }\end{array}$ & $\begin{array}{c}\text { Number of trees } \\
\text { planted and } \\
\text { survived ( } 3 \text { tree } \\
\text { seedlings) }\end{array}$ & $\begin{array}{l}\text { Additional tree } \\
\text { seedlings obtained } \\
\text { and planted }\end{array}$ \\
\hline & (1) & $(2)$ & (3) \\
\hline WTP (in ‘000 IDR) & $\begin{array}{c}0.02^{* * *} \\
(0.005)\end{array}$ & $\begin{array}{c}0.02 * * * \\
(0.005)\end{array}$ & $\begin{array}{c}0.11 \\
(0.12)\end{array}$ \\
\hline $\mathrm{N}$ & 198 & 198 & 198 \\
\hline \multicolumn{4}{|c|}{$\begin{array}{l}\text { Column (1) shows AME for the number of tree seedlings planted with control variables; column (2) reports AME for the } \\
\text { number of tree seedlings alive with control variables; column (3) shows AME for the number of tree seedlings obtained and } \\
\text { planted in addition with control variables; column (4) shows AME for the number of tree seedlings planted in oil palm and } \\
\text { rubber plantations and fallow land with control variables; column (5) reports AME for the number of tree seedlings alive } \\
\text { planted in oil palm and rubber plantations and fallow land with control variables; } \\
\text { Negative binomial regressions were applied. Besides the control variables, a pre-treatment dependent baseline variable } \\
\text { was included in all model specifications. } \\
\text { Control variables include age, education, whether the farmer was part of the transmigration program, a dummy if the } \\
\text { farmer has planted trees in his/her oil palm plantation in the last } 12 \text { months, the baseline dependent variable, land owned } \\
\text { (in ha), the distance from the nearest oil palm plantation to the house of the farmer (in km), and three different tree bundles } \\
\text { offered. } \\
\text { Standard errors clustered at village level in parentheses; } \\
\text { The full model can be found in the appendix (table A2.9); } \\
{ }^{*} p<0.1,{ }^{* *} p<0.05,{ }^{* * *} p<0.01\end{array}$} \\
\hline
\end{tabular}

Table 2.7: AME for the sub-sample T2

\subsection{Discussion and conclusion}

In this article, we compare the effects of two policy interventions on native tree planting, tree survival, and additional planting efforts. In the subsidy treatment, farmers are provided with information on native tree planting and a bundle of three native tree seedlings for free. The effects of the subsidy treatment are compared to the price treatment, in which farmers receive the same information as well as the opportunity to offer a price for a bundle of three tree seedlings under an auction mechanism. Native tree planting is a maintenance-intense agricultural technology that generates positive external effects for the environment. Due to the positive externalities, a subsidy may be justified from a societal perspective, but may also raise concerns over crowding out further investments into tree planting. Our results reveal that tree planting adoption, planting intensity, and survival rates are higher in the subsidy treatment than in the price treatment. However, farmers in the subsidy treatment tend to engage less in additional planting activities compared to farmers in the price treatment, although the differences are not statistically significant. 
Thus, our results support our first hypothesis that a subsidy increases native tree planting. This is in line with previous research by Rudolf et al. (2020) who find that information provision combined with an in-kind subsidy of six tree seedlings substantially increased the adoption of native tree planting. Similarly, Jack et al. (2015) find a positive effect of a take-up subsidy on native tree planting. These results underline the positive role that a subsidy can play in the promotion of a socially desirable good.

Regarding the effect of the subsidy on further investments in maintenance and additional tree planting our results are more mixed. Our second hypothesis that the subsidy results in lower tree survival finds no support in our data. Under higher planting intensities, the number of trees surviving after six months is still higher in the subsidy treatment than in the price treatment. Our third hypothesis, however, finds some tentative (although insignificant) support in our data: additional tree planting activities seem to be lower in the subsidy treatment than in the price treatment. This is in line with previous research finding evidence that subsidies for (partly maintenance-intense) technologies with positive externalities, such as conservation practices, can lead to motivational crowding out (Rode et al. 2015; Greiner and Gregg 2011).

These results are also reflected in our cost-effectiveness estimates. When considering only the three tree seedlings distributed in our interventions, there is no difference in cost-effectiveness between the two treatments, since the subsidy treatment is more costly, but also more effective. When taking additional tree planting activities into account, the price treatment is significantly more cost-effective, which hinges, however, on a relatively small number of farmers who engage in additional tree planting. Overall, we find rather low additional planting efforts in our sample, which is likely due to low preferences for native tree planting as well as limited market access to seed material. This finds support in our data since the average WTP for the three tree seedlings in the price treatment was substantially below the average market price of tree seedlings faced by farmers. In addition, many farmers mentioned that access to seedlings in their villages was difficult.

Considering these results, we refrain from a policy recommendation favoring one approach over another. It rather seems that a policy mix consisting of the distribution of subsidized tree seedlings in combination with value chain development of tree seedlings is likely to be more effective and address multiple barriers to native tree planting. Although our subsidy treatment was associated with crowding out additional investments, the subsidy also has some clear advantages. Through the distribution of free tree seedlings, we were able to reach a larger number of farmers and convince them to experiment with tree planting, than if they had to pay for the tree seedlings. For our sub-sample of farmers exposed to the price treatment, we could show that the average WTP for tree seedlings is below the average market price faced by farmers. Subsidies may thus be critical to overcome the gap between farmers' WTP for native tree seedlings and actual market prices. Also, in-kind subsidies offer 
the opportunity to influence which tree species farmers plant and accordingly the extent of biodiversity and associated environmental effects. Of course, farmers' preferences for different tree species (Van Noordwijk 2011), local knowledge on tree characteristics, the abundance and spatial distribution of species, and the variety of ecological and economic functions provided by different species need to be taken into account (Chazdon 2008).

Nonetheless, since the subsidy treatment tends to crowd out additional tree planting activities, it is less cost-effective than the price treatment. From a policy perspective, cost-effectiveness is an important decision criterion, given that public funds for conservation are generally scarce. Yet, some caution is warranted when interpreting our findings. As pointed out before, only a few farmers in our sample engaged in additional tree planting activities beyond the seedlings distributed in our treatments. The significant difference in cost-effectiveness of the two treatments thus depends on a few farmers exhibiting high levels of additional planting activities. Maybe even more importantly, it should be noted that our results reflect short-term effects measured six months after the implementation of the treatments. This time span is likely relevant to capture planting of the distributed trees and initial evidence on tree survival. Yet, it may be too short to adequately reflect further investments in tree planting, especially for those farmers who had no prior experience with native tree planting. Possibly farmers are experimenting with the technology and gathering experience to make more informed decisions later. In this context, the positive effect of the subsidy treatment on tree survival is encouraging, since it implies that farmers engage in maintenance, even though free seedlings are not necessarily targeted at those farmers with the highest WTP for tree seedlings.

Finally, value chain development is essential to enhance market access to high-quality tree seedlings in the villages. This could be achieved e.g. through the support of local nurseries for native tree species. Increasing local supply of high-quality seedlings may lead to lower market prices for native tree seedlings, thus reducing the gap between farmers' WTP and actual market prices faced by farmers in the villages. From the demand side, farmers' WTP for native tree seedlings may also increase as they gain more knowledge and experience the benefits of tree planting first-hand. This could be supported by information and training provided to farmers. That there is indeed demand for such knowledge is supported by our data, since 90 percent of the farmers in our sample stated that there is not enough information about native tree planting available in their villages. 


\section{Appendix}

\begin{tabular}{|c|c|c|c|c|}
\hline $\begin{array}{l}\text { Number of trees planted } \\
\text { (three tree seedlings) in home } \\
\text { gardens, oil palm, rubber, and } \\
\text { fallow land }\end{array}$ & $\begin{array}{l}\text { Adoption } \\
\text { decision }\end{array}$ & $\begin{array}{l}\text { Adoption } \\
\text { decision }\end{array}$ & $\begin{array}{c}\text { Number of trees } \\
\text { planted }\end{array}$ & $\begin{array}{c}\text { Number of trees } \\
\text { planted }\end{array}$ \\
\hline & (1) & $(2)$ & (3) & (4) \\
\hline $\mathrm{T} 1$ & $\begin{array}{c}0.15^{* * *} \\
(0.05) \\
\end{array}$ & $\begin{array}{c}0.17^{* * *} \\
(0.05) \\
\end{array}$ & $\begin{array}{c}0.36^{* * *} \\
(0.12)\end{array}$ & $\begin{array}{c}0.46 * * * \\
(0.13)\end{array}$ \\
\hline Age & & $\begin{array}{c}0.002 \\
(0.003) \\
\end{array}$ & & $\begin{array}{c}0.005 \\
(0.005) \\
\end{array}$ \\
\hline Education in years & & $\begin{array}{l}0.0006 \\
(0.005) \\
\end{array}$ & & $\begin{array}{l}0.0007 \\
(0.01) \\
\end{array}$ \\
\hline Transmigration program (1/0) & & $\begin{array}{l}-0.10 \\
(0.06) \\
\end{array}$ & & $\begin{array}{c}-0.43 * * * \\
(0.14) \\
\end{array}$ \\
\hline $\begin{array}{l}\text { Trees planted in oil palm in } \\
\text { the last } 12 \text { months }(1 / 0)\end{array}$ & & $\begin{array}{c}0.06 \\
(0.06)\end{array}$ & & $\begin{array}{l}0.23^{*} \\
(0.14)\end{array}$ \\
\hline $\begin{array}{l}\text { Number of trees in oil palm } \\
\text { plantation and home garden } \\
\text { per ha }\end{array}$ & & $\begin{array}{c}0.003 \\
(0.004)\end{array}$ & & $\begin{array}{l}0.003 \\
(0.006)\end{array}$ \\
\hline Land owned (in ha) & & $\begin{array}{l}0.0006 \\
(0.004)\end{array}$ & & $\begin{array}{c}0.004 \\
(0.009)\end{array}$ \\
\hline $\begin{array}{l}\text { Distance nearest oil palm } \\
\text { plantation to the house (in } \\
\mathrm{km} \text { ) }\end{array}$ & & $\begin{array}{c}0.003 \\
(0.002)\end{array}$ & & $\begin{array}{l}0.009 \\
(0.005)\end{array}$ \\
\hline $\begin{array}{l}\text { Tree bundle } 1 \text { (Duku, Meranti, } \\
\text { Mangosteen) (1/0) }\end{array}$ & & $\begin{array}{c}0.18^{* * *} \\
(0.04)\end{array}$ & & $\begin{array}{c}0.42^{* * *} \\
(0.15)\end{array}$ \\
\hline $\begin{array}{l}\text { Tree bundle } 2 \text { (Durian, Duku, } \\
\text { Meranti) }(1 / 0)\end{array}$ & & $\begin{array}{c}0.18^{* * *} \\
(0.06)\end{array}$ & & $\begin{array}{c}0.38^{* * *} \\
(0.14)\end{array}$ \\
\hline $\begin{array}{l}\text { Tree bundle } 4 \text { (Durian, } \\
\text { Meranti, Mangosteen) (1/0) }\end{array}$ & & $\begin{array}{l}-0.05 \\
(0.05)\end{array}$ & & $\begin{array}{l}-0.03 \\
(0.16)\end{array}$ \\
\hline Control variables included & no & yes & no & yes \\
\hline $\mathrm{N}$ & 397 & 397 & 397 & 397 \\
\hline \multicolumn{5}{|c|}{$\begin{array}{l}\text { Column (1) shows AME for the adoption decision with control variables; column (2) shows AME for the adoption decision } \\
\text { without control variables; column (3) reports AME for the number of trees planted with control variables; column (4) shows } \\
\text { AME for the number of trees planted without control variables; } \\
\text { Besides the control variables, a pre-treatment dependent baseline variable was included in all model specifications and one } \\
\text { interaction term. } \\
\text { Control variables include age, education, whether the farmer was part of the transmigration program, a dummy if the } \\
\text { farmer has planted trees in his/her oil palm plantation in the last } 12 \text { months, the baseline dependent variable, land owned } \\
\text { (in ha), the distance from the nearest oil palm plantation to the house of the farmer (in } \mathrm{km} \text { ), and three different tree bundles } \\
\text { offered; } \\
\text { Standard errors clustered at village level in parentheses; } \\
{ }^{*} p<0.1,{ }^{* *} p<0.05,{ }^{* * *} p<0.01\end{array}$} \\
\hline
\end{tabular}

Table A2.1: ITT effects of planting trees in home gardens, oil palm, rubber, and fallow land 
Chapter 2: How to promote agricultural technologies that generate positive environmental effects? Evidence on tree planting in Indonesia

\begin{tabular}{|c|c|c|c|c|}
\hline $\begin{array}{l}\text { Number of trees planted } \\
\text { (three tree seedlings) in oil } \\
\text { palm and rubber, and fallow } \\
\text { land }\end{array}$ & $\begin{array}{l}\text { Adoption } \\
\text { decision }\end{array}$ & $\begin{array}{c}\text { Adoption } \\
\text { decision }\end{array}$ & $\begin{array}{c}\text { Number of trees } \\
\text { planted }\end{array}$ & $\begin{array}{c}\text { Number of trees } \\
\text { planted }\end{array}$ \\
\hline & (1) & $(2)$ & (3) & (4) \\
\hline $\mathrm{T} 1$ & $\begin{array}{l}0.11^{*} \\
(0.06)\end{array}$ & $\begin{array}{c}0.12^{* * *} \\
(0.05)\end{array}$ & $\begin{array}{c}0.26 \\
(0.16)\end{array}$ & $\begin{array}{c}0.32^{* * *} \\
(0.12)\end{array}$ \\
\hline Age & & $\begin{array}{c}0.001 \\
(0.001)\end{array}$ & & $\begin{array}{l}0.0009 \\
(0.003)\end{array}$ \\
\hline Education in years & & $\begin{array}{c}0.005 \\
(0.006)\end{array}$ & & $\begin{array}{c}0.01 \\
(0.01)\end{array}$ \\
\hline Transmigration program (1/0) & & $\begin{array}{c}-0.15^{* * *} \\
(0.05)\end{array}$ & & $\begin{array}{c}-0.55^{* * *} \\
(0.19)\end{array}$ \\
\hline $\begin{array}{l}\text { Trees planted in oil palm in } \\
\text { the last } 12 \text { months }(1 / 0)\end{array}$ & & $\begin{array}{c}0.06 \\
(0.04) \\
\end{array}$ & & $\begin{array}{c}0.25^{* * *} \\
(0.08)\end{array}$ \\
\hline $\begin{array}{l}\text { Number of trees in oil palm } \\
\text { plantations per ha }\end{array}$ & & $\begin{array}{l}0.02 * * \\
(0.007) \\
\end{array}$ & & $\begin{array}{c}0.01 \\
(0.01)\end{array}$ \\
\hline Land owned (in ha) & & $\begin{array}{l}-0.0004 \\
(0.002)\end{array}$ & & $\begin{array}{l}-0.001 \\
(0.004)\end{array}$ \\
\hline $\begin{array}{l}\text { Distance nearest oil palm } \\
\text { plantation to the house (in } \\
\mathrm{km} \text { ) }\end{array}$ & & $\begin{array}{l}0.0009 \\
(0.002)\end{array}$ & & $\begin{array}{c}0.002 \\
(0.005)\end{array}$ \\
\hline $\begin{array}{l}\text { Tree bundle } 1 \text { (Duku, Meranti, } \\
\text { Mangosteen) (1/0) }\end{array}$ & & $\begin{array}{l}-0.08 \\
(0.05)\end{array}$ & & $\begin{array}{l}-0.10 \\
(0.17)\end{array}$ \\
\hline $\begin{array}{l}\text { Tree bundle } 2 \text { (Durian, Duku, } \\
\text { Meranti) }(1 / 0)\end{array}$ & & $\begin{array}{c}0.05 \\
(0.05) \\
\end{array}$ & & $\begin{array}{c}0.22 \\
(0.16) \\
\end{array}$ \\
\hline $\begin{array}{l}\text { Tree bundle } 4 \text { (Durian, } \\
\text { Meranti, Mangosteen) }(1 / 0)\end{array}$ & & $\begin{array}{c}-0.22 * * * \\
(0.05)\end{array}$ & & $\begin{array}{c}-0.41^{* * *} \\
(0.16)\end{array}$ \\
\hline Control variables included & no & yes & no & yes \\
\hline $\mathrm{N}$ & 397 & 397 & 397 & 397 \\
\hline \multicolumn{5}{|c|}{$\begin{array}{l}\text { Column (1) shows AME for the adoption decision with control variables; column (2) shows AME for the adoption decision } \\
\text { without control variables; column (3) reports AME for the number of trees planted with control variables; column (4) shows } \\
\text { AME for the number of trees planted without control variables; } \\
\text { Besides the control variables, a pre-treatment dependent baseline variable was included in all model specifications and one } \\
\text { interaction term. } \\
\text { Control variables include age, education, whether the farmer was part of the transmigration program, a dummy if the } \\
\text { farmer has planted trees in his/her oil palm plantation in the last } 12 \text { months, the baseline dependent variable, land owned } \\
\text { (in ha), the distance from the nearest oil palm plantation to the house of the farmer (in km), and three different tree bundles } \\
\text { offered; } \\
\text { Standard errors clustered at village level in parentheses; }\end{array}$} \\
\hline
\end{tabular}

Table A2.2: ITT effects of planting trees in oil palm and rubber plantations, and fallow land 
Chapter 2: How to promote agricultural technologies that generate positive environmental effects? Evidence on tree planting in Indonesia

\begin{tabular}{|c|c|c|}
\hline $\begin{array}{l}\text { Number of trees that survived (three tree } \\
\text { seedlings) planted in home gardens, oil palm, } \\
\text { rubber, and fallow land }\end{array}$ & $\begin{array}{l}\text { Number of trees that } \\
\text { survived }\end{array}$ & $\begin{array}{l}\text { Number of trees that } \\
\text { survived }\end{array}$ \\
\hline & (1) & (2) \\
\hline T1 & $\begin{array}{c}0.25 * * * \\
(0.08)\end{array}$ & $\begin{array}{c}0.30 * * * \\
(0.08)\end{array}$ \\
\hline Age & & $\begin{array}{c}0.003 \\
(0.005)\end{array}$ \\
\hline Education in years & & $\begin{array}{l}0.0002 \\
(0.009)\end{array}$ \\
\hline Transmigration program (1/0) & & $\begin{array}{c}-0.21^{* *} \\
(0.08)\end{array}$ \\
\hline $\begin{array}{l}\text { Trees planted in oil palm in the last } 12 \text { months } \\
(1 / 0)\end{array}$ & & $\begin{array}{c}0.13 \\
(0.10)\end{array}$ \\
\hline $\begin{array}{l}\text { Number of trees in oil palm plantation and } \\
\text { home garden per ha }\end{array}$ & & $\begin{array}{c}0.004 \\
(0.003)\end{array}$ \\
\hline Land owned (in ha) & & $\begin{array}{l}-0.0001 \\
(0.006)\end{array}$ \\
\hline $\begin{array}{l}\text { Distance nearest oil palm plantation to the } \\
\text { house (in } \mathrm{km} \text { ) }\end{array}$ & & $\begin{array}{l}0.007^{* *} \\
(0.003)\end{array}$ \\
\hline $\begin{array}{l}\text { Tree bundle } 1 \text { (Duku, Meranti, Mangosteen) } \\
(1 / 0)\end{array}$ & & $\begin{array}{c}0.51^{* * *} \\
(0.12)\end{array}$ \\
\hline Tree bundle 2 (Durian, Duku, Meranti) (1/0) & & $\begin{array}{c}0.38 * * * \\
(0.13)\end{array}$ \\
\hline $\begin{array}{l}\text { Tree bundle } 4 \text { (Durian, Meranti, Mangosteen) } \\
(1 / 0)\end{array}$ & & $\begin{array}{c}0.15 \\
(0.14)\end{array}$ \\
\hline Control variables included & no & yes \\
\hline $\mathrm{N}$ & 397 & 397 \\
\hline \multicolumn{3}{|c|}{$\begin{array}{l}\text { Column (1) reports the AME for the number of trees alive; column (2) also reports the AME for the number of } \\
\text { trees alive but without control variables included. A negative binomial regression was applied. Besides the } \\
\text { control variables, a pre-treatment dependent baseline variable was included in all model specifications and } \\
\text { one interaction term. } \\
\text { Control variables include age, education, whether the farmer was part of the transmigration program, a } \\
\text { dummy if the farmer has planted trees in his/her oil palm plantation in the last } 12 \text { months, the baseline } \\
\text { dependent variable, land owned (in ha), the distance from the nearest oil palm plantation to the house of the } \\
\text { farmer (in km), and three different tree bundles offered. } \\
\text { Standard errors clustered at village level in parentheses; }\end{array}$} \\
\hline
\end{tabular}

Table A2.3: ITT effects for the number of trees alive (three tree seedlings) for trees planted in home gardens, oil palm, rubber, and fallow land 
Chapter 2: How to promote agricultural technologies that generate positive environmental effects? Evidence on tree planting in Indonesia

\begin{tabular}{|c|c|c|}
\hline $\begin{array}{l}\text { Number of trees that survived (three tree } \\
\text { seedlings) planted in oil palm, rubber, and } \\
\text { fallow land }\end{array}$ & $\begin{array}{l}\text { Number of trees that } \\
\text { survived }\end{array}$ & $\begin{array}{l}\text { Number of trees that } \\
\text { survived }\end{array}$ \\
\hline & $(1)$ & $(2)$ \\
\hline $\mathrm{T} 1$ & $\begin{array}{c}0.15 \\
(0.10)\end{array}$ & $\begin{array}{l}0.20^{* *} \\
(0.09)\end{array}$ \\
\hline Age & & $\begin{array}{r}-0.0001 \\
(0.003) \\
\end{array}$ \\
\hline Education in years & & $\begin{array}{l}0.006 \\
(0.01)\end{array}$ \\
\hline Transmigration program (1/0) & & $\begin{array}{c}-0.38^{* *} \\
(0.16)\end{array}$ \\
\hline $\begin{array}{l}\text { Trees planted in oil palm in the last } 12 \text { months } \\
(1 / 0)\end{array}$ & & $\begin{array}{c}0.15^{* *} \\
(0.06)\end{array}$ \\
\hline Number of trees in oil palm plantations per ha & & $\begin{array}{c}0.007 \\
(0.006)\end{array}$ \\
\hline Land owned (in ha) & & $\begin{array}{c}0.002 \\
(0.004)\end{array}$ \\
\hline $\begin{array}{l}\text { Distance nearest oil palm plantation to the } \\
\text { house (in } \mathrm{km} \text { ) }\end{array}$ & & $\begin{array}{l}-0.005 \\
(0.006)\end{array}$ \\
\hline $\begin{array}{l}\text { Tree bundle } 1 \text { (Duku, Meranti, Mangosteen) } \\
(1 / 0)\end{array}$ & & $\begin{array}{l}0.006 \\
(0.09)\end{array}$ \\
\hline Tree bundle 2 (Durian, Duku, Meranti) (1/0) & & $\begin{array}{l}0.22^{* *} \\
(0.10)\end{array}$ \\
\hline $\begin{array}{l}\text { Tree bundle } 4 \text { (Durian, Meranti, Mangosteen) } \\
(1 / 0)\end{array}$ & & $\begin{array}{l}-0.27^{*} \\
(0.15)\end{array}$ \\
\hline Control variables included & no & yes \\
\hline $\mathrm{N}$ & 397 & 397 \\
\hline \multicolumn{3}{|c|}{$\begin{array}{l}\text { Column (1) reports the AME for the number of trees alive; column (2) also reports the AME for the number of } \\
\text { trees alive but without control variables included. A negative binomial regression was applied. Besides the } \\
\text { control variables, a pre-treatment dependent baseline variable was included in all model specifications and } \\
\text { one interaction term. } \\
\text { Control variables include age, education, whether the farmer was part of the transmigration program, a } \\
\text { dummy if the farmer has planted trees in his/her oil palm plantation in the last } 12 \text { months, the baseline } \\
\text { dependent variable, land owned (in ha), the distance from the nearest oil palm plantation to the house of the } \\
\text { farmer (in km), and three different tree bundles offered; } \\
\text { Standard errors clustered at village level in parentheses; } \\
{ }^{*} p<0.1,{ }^{* *} p<0.05,{ }^{* * *} p<0.01\end{array}$} \\
\hline
\end{tabular}

Table A2.4: ITT effects for the number of trees alive (three tree seedlings) for trees planted in oil palm and rubber plantations and fallow land 
Chapter 2: How to promote agricultural technologies that generate positive environmental effects? Evidence on tree planting in Indonesia

\begin{tabular}{|c|c|c|c|c|}
\hline $\begin{array}{l}\text { Additional tree seedlings } \\
\text { obtained and planted in } \\
\text { home gardens, oil palm, } \\
\text { rubber, and fallow land }\end{array}$ & $\begin{array}{l}\text { Adoption } \\
\text { decision }\end{array}$ & $\begin{array}{l}\text { Adoption } \\
\text { decision }\end{array}$ & $\begin{array}{c}\text { Number of trees } \\
\text { planted }\end{array}$ & $\begin{array}{c}\text { Number of trees } \\
\text { planted }\end{array}$ \\
\hline & $(1)$ & $(2)$ & (3) & $(4)$ \\
\hline $\mathrm{T} 1$ & $\begin{array}{l}-0.04 \\
(0.03) \\
\end{array}$ & $\begin{array}{l}-0.03 \\
(0.02) \\
\end{array}$ & $\begin{array}{l}-4.46 \\
(3.10) \\
\end{array}$ & $\begin{array}{l}-3.26 \\
(3.75) \\
\end{array}$ \\
\hline Age & & $\begin{array}{l}-0.003 * \\
(0.002) \\
\end{array}$ & & $\begin{array}{l}-0.07 \\
(0.10) \\
\end{array}$ \\
\hline Education in years & & $\begin{array}{l}0.008^{* *} \\
(0.004)\end{array}$ & & $\begin{array}{c}0.34 \\
(0.46)\end{array}$ \\
\hline $\begin{array}{l}\text { Transmigration program } \\
(1 / 0)\end{array}$ & & $\begin{array}{c}0.01 \\
(0.03)\end{array}$ & & $\begin{array}{l}-0.19 \\
(1.08)\end{array}$ \\
\hline $\begin{array}{l}\text { Trees planted in oil palm in } \\
\text { the last } 12 \text { months }(1 / 0)\end{array}$ & & $\begin{array}{c}0.05 \\
(0.03) \\
\end{array}$ & & $\begin{array}{c}1.33 \\
(1.94) \\
\end{array}$ \\
\hline $\begin{array}{l}\text { Number of trees in oil palm } \\
\text { plantation and home garden } \\
\text { per ha }\end{array}$ & & $\begin{array}{l}-0.002 \\
(0.003)\end{array}$ & & $\begin{array}{l}-0.07 \\
(0.06)\end{array}$ \\
\hline Land owned (in ha) & & $\begin{array}{c}0.002 \\
(0.002) \\
\end{array}$ & & $\begin{array}{c}0.12 \\
(0.17) \\
\end{array}$ \\
\hline $\begin{array}{l}\text { Distance nearest oil palm } \\
\text { plantation to the house (in } \\
\mathrm{km} \text { ) }\end{array}$ & & $\begin{array}{c}-0.004^{* *} \\
(0.001)\end{array}$ & & $\begin{array}{l}0.10 \\
(0.28)\end{array}$ \\
\hline $\begin{array}{l}\text { Tree bundle } 1 \text { (Duku, } \\
\text { Meranti, Mangosteen) (1/0) }\end{array}$ & & $\begin{array}{l}-0.04 \\
(0.04) \\
\end{array}$ & & $\begin{array}{l}-3.07 \\
(4.34) \\
\end{array}$ \\
\hline $\begin{array}{l}\text { Tree bundle } 2 \text { (Durian, Duku, } \\
\text { Meranti) }(1 / 0)\end{array}$ & & $\begin{array}{l}-0.06 \\
(0.04)\end{array}$ & & $\begin{array}{c}0.02 \\
(1.24)\end{array}$ \\
\hline $\begin{array}{l}\text { Tree bundle } 4 \text { (Durian, } \\
\text { Meranti, Mangosteen) }(1 / 0)\end{array}$ & & $\begin{array}{l}-0.02 \\
(0.04)\end{array}$ & & $\begin{array}{c}0.07 \\
(1.45)\end{array}$ \\
\hline Control variables included & no & yes & no & yes \\
\hline $\mathrm{N}$ & 397 & 397 & 397 & 397 \\
\hline \multicolumn{5}{|c|}{$\begin{array}{l}\text { Column (1) reports the AME for the adoption decision to obtain tree seedlings without control variables; column (2) } \\
\text { also reports AME for the adoption decision to obtain tree seedlings but with control variables; column (3) shows } \\
\text { AME for the number of additional tree seedlings planted without control variables; column (4) reports the AME for } \\
\text { the number of additional tree seedlings planted with control variables included. A negative binomial regression was } \\
\text { applied. Besides the control variables, a pre-treatment dependent baseline variable was included in all model } \\
\text { specifications and one interaction term. } \\
\text { Control variables include age, education, whether the farmer was part of the transmigration program, a dummy if } \\
\text { the farmer has planted trees in his/her oil palm plantation in the last } 12 \text { months, the baseline dependent variable, } \\
\text { land owned (in ha), the distance from the nearest oil palm plantation to the house of the farmer (in km), and three } \\
\text { different tree bundles offered; } \\
\text { Standard errors clustered at village level in parentheses; } \\
{ }^{*} p<0.1,{ }^{* *} p<0.05,{ }^{* * *} p<0.01\end{array}$} \\
\hline
\end{tabular}

Table A2.5: ITT effects for additionally obtained tree seedlings planted in home gardens, oil palm, rubber, and fallow land 
Chapter 2: How to promote agricultural technologies that generate positive environmental effects? Evidence on tree planting in Indonesia

\begin{tabular}{|c|c|c|c|c|}
\hline & \multicolumn{2}{|c|}{ Without additional tree seedlings obtained } & \multicolumn{2}{|c|}{ With additional tree seedlings obtained } \\
\hline & $(1)$ & (2) & (3) & (4) \\
\hline & $\begin{array}{l}\text { Trees planted per } \\
\text { USD spent }\end{array}$ & $\begin{array}{c}\text { Trees planted and } \\
\text { survived per USD } \\
\text { spent }\end{array}$ & $\begin{array}{l}\text { Trees planted per } \\
\text { USD spent }\end{array}$ & $\begin{array}{c}\text { Trees planted and } \\
\text { survived per USD } \\
\text { spent }\end{array}$ \\
\hline Overall & $\begin{array}{c}0.03 \\
(0.07) \\
\end{array}$ & $\begin{array}{c}0.02 \\
(0.06) \\
\end{array}$ & $\begin{array}{c}0.15 \\
(1.63) \\
\end{array}$ & $\begin{array}{c}0.14 \\
(1.59) \\
\end{array}$ \\
\hline T1 & $\begin{array}{l}0.04 \\
(0.07)\end{array}$ & $\begin{array}{l}0.03 \\
(0.06)\end{array}$ & $\begin{array}{l}0.04 \\
(0.07)\end{array}$ & $\begin{array}{c}0.03 \\
(0.06)\end{array}$ \\
\hline $\mathrm{T} 2$ & $\begin{array}{c}0.03 \\
(0.07) \\
\end{array}$ & $\begin{array}{c}0.02 \\
(0.06) \\
\end{array}$ & $\begin{array}{c}0.26 \\
(2.30) \\
\end{array}$ & $\begin{array}{c}0.25 \\
(2.25) \\
\end{array}$ \\
\hline $\begin{array}{l}\mathrm{T} 1=\mathrm{T} 2 \\
\text { ( } p \text {-values) }\end{array}$ & 0.22 & 0.41 & $0.00 * * *$ & $0.00 * * *$ \\
\hline $\mathrm{N}$ & \multicolumn{4}{|c|}{397 farmers with 199 farmers in T1 and 198 in T2 } \\
\hline \multicolumn{5}{|c|}{$\begin{array}{l}\text { The cost-effectiveness analysis was done by dividing the number of trees planted or survived per farmer by the } \\
\text { costs per capita of the intervention. As we did not have a control group, our baseline value for the number of } \\
\text { trees planted was zero. } \\
\text { Differences in the cost-effectiveness between T1 and T2 were tested with negative binomial regression models } \\
\text { regressing the treatment variable on the respective outcome variable with standard errors clustered at village } \\
\text { level. } \\
\text { Costs were transformed from IDR to USD using a conversion rate from June 2019. To reflect on the true cost } \\
\text { involved we assume that the farmers in treatment arm T2 pay for the tree seedlings by themselves. } \\
{ }^{*} p<0.1,{ }^{* *} p<0.05,{ }^{* * *} p<0.01\end{array}$} \\
\hline
\end{tabular}

Table A2.6: Cost-effectiveness for the trees planted in oil palm and rubber plantations and fallow land

\begin{tabular}{|c|c|c|c|c|}
\hline & \multicolumn{2}{|c|}{ Without additional tree seedlings obtained } & \multicolumn{2}{|c|}{ With additional tree seedlings obtained } \\
\hline & $(1)$ & $(2)$ & (3) & $(4)$ \\
\hline & $\begin{array}{l}\text { Trees planted per } \\
\text { USD spent }\end{array}$ & $\begin{array}{c}\text { Trees planted and } \\
\text { survived per USD } \\
\text { spent }\end{array}$ & $\begin{array}{c}\text { Trees planted per } \\
\text { USD spent }\end{array}$ & $\begin{array}{c}\text { Trees planted and } \\
\text { survived per USD } \\
\text { spent }\end{array}$ \\
\hline Overall & $\begin{array}{c}0.07 \\
(0.09) \\
\end{array}$ & $\begin{array}{c}0.05 \\
(0.07) \\
\end{array}$ & $\begin{array}{c}0.10 \\
(0.15) \\
\end{array}$ & $\begin{array}{c}0.08 \\
(0.12) \\
\end{array}$ \\
\hline $\mathrm{T} 1$ & $\begin{array}{c}0.08 \\
(0.08) \\
\end{array}$ & $\begin{array}{c}0.06 \\
(0.07) \\
\end{array}$ & $\begin{array}{c}0.09 \\
(0.11) \\
\end{array}$ & $\begin{array}{c}0.07 \\
(0.09) \\
\end{array}$ \\
\hline $\mathrm{T} 2$ & $\begin{array}{c}0.06 \\
(0.09) \\
\end{array}$ & $\begin{array}{c}0.05 \\
(0.08) \\
\end{array}$ & $\begin{array}{c}0.10 \\
(0.18) \\
\end{array}$ & $\begin{array}{c}0.08 \\
(0.15) \\
\end{array}$ \\
\hline $\begin{array}{l}\mathrm{T} 1=\mathrm{T} 2 \\
\text { ( } \mathrm{p} \text {-values) }\end{array}$ & 0.14 & 0.21 & 0.48 & 0.26 \\
\hline $\mathrm{N}$ & \multicolumn{4}{|c|}{397 farmers with 199 farmers in T1 and 198 in T2 } \\
\hline \multicolumn{5}{|c|}{$\begin{array}{l}\text { The cost-effectiveness analysis was done by dividing the number of trees planted or survived per farmer by the } \\
\text { costs per capita of the intervention. As we did not have a control group, our baseline value for the number of } \\
\text { trees planted was zero. } \\
\text { Differences in the cost-effectiveness between T1 and T2 were tested with negative binomial regression models } \\
\text { regressing the treatment variable on the respective outcome variable with standard errors clustered at village } \\
\text { level. } \\
\text { Costs were transformed from IDR to USD using a conversion rate from June 2019. To reflect on the true cost } \\
\text { involved we assume that the farmers in treatment arm T2 pay for the tree seedlings by themselves. } \\
\text { The distribution of the outcome variables for columns (3) and (4) are winsorized at the } 99^{\text {th }} \text { percentile. } \\
{ }^{*} p<0.1,{ }^{* *} p<0.05,{ }^{* * *} p<0.01\end{array}$} \\
\hline
\end{tabular}

Table A2.7: Cost-effectiveness for the trees planted in home gardens, oil palm, rubber, and fallow land 


\begin{tabular}{|c|c|c|c|c|}
\hline & \multicolumn{2}{|c|}{ Without additional tree seedlings obtained } & \multicolumn{2}{|c|}{ With additional tree seedlings obtained } \\
\hline & $(1)$ & (2) & (3) & (4) \\
\hline & $\begin{array}{c}\text { Trees planted per } \\
\text { USD spent }\end{array}$ & $\begin{array}{c}\text { Trees planted and } \\
\text { survived per USD } \\
\text { spent }\end{array}$ & $\begin{array}{l}\text { Trees planted per } \\
\text { USD spent }\end{array}$ & $\begin{array}{c}\text { Trees planted and } \\
\text { survived per USD } \\
\text { spent }\end{array}$ \\
\hline Overall & $\begin{array}{c}0.03 \\
(0.07) \\
\end{array}$ & $\begin{array}{c}0.02 \\
(0.06) \\
\end{array}$ & $\begin{array}{c}0.03 \\
(0.06) \\
\end{array}$ & $\begin{array}{c}0.03 \\
(0.06) \\
\end{array}$ \\
\hline $\mathrm{T} 1$ & $\begin{array}{c}0.04 \\
(0.07)\end{array}$ & $\begin{array}{c}0.03 \\
(0.06)\end{array}$ & $\begin{array}{c}0.03 \\
(0.06)\end{array}$ & $\begin{array}{c}0.03 \\
(0.06)\end{array}$ \\
\hline $\mathrm{T} 2$ & $\begin{array}{c}0.03 \\
(0.07) \\
\end{array}$ & $\begin{array}{c}0.02 \\
(0.06) \\
\end{array}$ & $\begin{array}{c}0.03 \\
(0.07) \\
\end{array}$ & $\begin{array}{c}0.03 \\
(0.07) \\
\end{array}$ \\
\hline $\begin{array}{l}\mathrm{T} 1=\mathrm{T} 2 \\
\text { ( } \mathrm{p} \text {-values) }\end{array}$ & 0.22 & 0.41 & 0.97 & 0.97 \\
\hline $\mathrm{N}$ & \multicolumn{4}{|c|}{397 farmers with 199 farmers in T1 and 198 in T2 } \\
\hline \multicolumn{5}{|c|}{$\begin{array}{l}\text { The cost-effectiveness analysis was done by dividing the number of trees planted or survived per farmer by the } \\
\text { costs per capita of the intervention. As we did not have a control group, our baseline value for the number of } \\
\text { trees planted was zero. } \\
\text { Differences in the cost-effectiveness between T1 and T2 were tested with negative binomial regression models } \\
\text { regressing the treatment variable on the respective outcome variable with standard errors clustered at village } \\
\text { level. } \\
\text { Costs were transformed from IDR to USD using a conversion rate from June 2019. To reflect on the true cost } \\
\text { involved we assume that the farmers in treatment arm T2 pay for the tree seedlings by themselves. } \\
\text { The distribution of the outcome variables for columns (3) and (4) are winsorized at the } 99^{\text {th }} \text { percentile. } \\
{ }^{*} p<0.1,{ }^{* *} p<0.05,{ }^{* * *} p<0.01\end{array}$} \\
\hline
\end{tabular}

Table A2.8: Cost-effectiveness for the trees planted in oil palm and rubber plantations and fallow land 
Chapter 2: How to promote agricultural technologies that generate positive environmental effects? Evidence on tree planting in Indonesia

\begin{tabular}{|c|c|c|c|c|c|}
\hline & \multicolumn{3}{|c|}{$\begin{array}{l}\text { Home gardens, oil palm and rubber plantations, and } \\
\text { fallow land }\end{array}$} & \multicolumn{2}{|c|}{$\begin{array}{l}\text { Oil palm and rubber plantations } \\
\text { and fallow land }\end{array}$} \\
\hline & $\begin{array}{l}\text { Number of } \\
\text { trees planted } \\
\text { ( } 3 \text { tree } \\
\text { seedlings) }\end{array}$ & $\begin{array}{l}\text { Number of trees } \\
\text { planted and } \\
\text { survived ( } 3 \text { tree } \\
\text { seedlings) }\end{array}$ & $\begin{array}{l}\text { Additional tree } \\
\text { seedlings } \\
\text { obtained and } \\
\text { planted }\end{array}$ & $\begin{array}{l}\text { Number of } \\
\text { trees planted } \\
\text { ( } 3 \text { tree } \\
\text { seedlings) }\end{array}$ & $\begin{array}{l}\text { Number of trees } \\
\text { planted and } \\
\text { survived ( } 3 \text { tree } \\
\text { seedlings) }\end{array}$ \\
\hline & (1) & (2) & (3) & (4) & (5) \\
\hline Age & $\begin{array}{l}-0.005 \\
(0.01)\end{array}$ & $\begin{array}{c}-0.001 \\
(0.008)\end{array}$ & $\begin{array}{c}0.11 \\
(0.15)\end{array}$ & $\begin{array}{c}-0.004 \\
(0.009)\end{array}$ & $\begin{array}{l}-0.005 \\
(0.006)\end{array}$ \\
\hline Education in years & $\begin{array}{l}-0.02 \\
(0.02)\end{array}$ & $\begin{array}{c}-0.01 \\
(0.009)\end{array}$ & $\begin{array}{l}-0.07 \\
(0.23)\end{array}$ & $\begin{array}{l}-0.01 \\
(0.01)\end{array}$ & $\begin{array}{c}-0.01 \\
(0.008)\end{array}$ \\
\hline $\begin{array}{l}\text { Transmigration program } \\
(1 / 0)\end{array}$ & $\begin{array}{l}-0.09 \\
(0.07)\end{array}$ & $\begin{array}{l}-0.07 \\
(0.09)\end{array}$ & $\begin{array}{l}-3.03 \\
(2.22)\end{array}$ & $\begin{array}{l}-0.19 \\
(0.17)\end{array}$ & $\begin{array}{l}-0.19 \\
(0.14)\end{array}$ \\
\hline $\begin{array}{l}\text { Trees planted in oil } \\
\text { palm in the last } 12 \\
\text { months }(1 / 0)\end{array}$ & $\begin{array}{c}0.26^{* *} \\
(0.12)\end{array}$ & $\begin{array}{c}0.14 \\
(0.09)\end{array}$ & $\begin{array}{c}5.11 \\
(10.12)\end{array}$ & $\begin{array}{c}0.22 * * * \\
(0.08)\end{array}$ & $\begin{array}{c}0.15^{* *} \\
(0.06)\end{array}$ \\
\hline $\begin{array}{l}\text { Number of trees in oil } \\
\text { palm and home garden } \\
\text { per ha }\end{array}$ & $\begin{array}{c}0.01 \\
(0.02)\end{array}$ & $\begin{array}{l}0.005 \\
(0.01)\end{array}$ & $\begin{array}{l}-0.54 \\
(0.79)\end{array}$ & - & - \\
\hline $\begin{array}{l}\text { Number of trees in oil } \\
\text { palm plantations per ha }\end{array}$ & - & - & - & $\begin{array}{l}0.03^{* *} \\
(0.01)\end{array}$ & $\begin{array}{l}0.03^{*} \\
(0.01)\end{array}$ \\
\hline Land owned (in ha) & $\begin{array}{l}-0.004 \\
(0.009)\end{array}$ & $\begin{array}{c}-0.01 \\
(0.007)\end{array}$ & $\begin{array}{c}0.27 \\
(0.42)\end{array}$ & $\begin{array}{r}-0.0008 \\
(0.004)\end{array}$ & $\begin{array}{l}0.0007 \\
(0.002)\end{array}$ \\
\hline $\begin{array}{l}\text { Distance nearest oil } \\
\text { palm plantation to the } \\
\text { house (in } \mathrm{km} \text { ) }\end{array}$ & $\begin{array}{c}0.008 \\
(0.005)\end{array}$ & $\begin{array}{c}0.005 \\
(0.003)\end{array}$ & $\begin{array}{c}0.04 \\
(0.31)\end{array}$ & $\begin{array}{c}0.001 \\
(0.003)\end{array}$ & $\begin{array}{c}-0.01 \\
(0.009)\end{array}$ \\
\hline $\begin{array}{l}\text { Tree bundle } 1 \text { (Duku, } \\
\text { Meranti, Mangosteen) } \\
(1 / 0)\end{array}$ & $\begin{array}{c}0.18 \\
(0.20)\end{array}$ & $\begin{array}{c}0.17 \\
(0.20)\end{array}$ & $\begin{array}{c}-11.21 \\
(12.81)\end{array}$ & $\begin{array}{c}0.03 \\
(0.16)\end{array}$ & $\begin{array}{l}-0.07 \\
(0.11)\end{array}$ \\
\hline $\begin{array}{l}\text { Tree bundle } 2 \text { (Durian, } \\
\text { Duku, Meranti) }(1 / 0)\end{array}$ & $\begin{array}{c}0.25 \\
(0.27)\end{array}$ & $\begin{array}{c}0.18 \\
(0.25)\end{array}$ & $\begin{array}{c}1.89 \\
(2.48)\end{array}$ & $\begin{array}{c}0.42^{* * *} \\
(0.16)\end{array}$ & $\begin{array}{c}0.29 * * * \\
(0.09)\end{array}$ \\
\hline $\begin{array}{l}\text { Tree bundle } 4 \text { (Durian, } \\
\text { Meranti, Mangosteen) } \\
(1 / 0)\end{array}$ & $\begin{array}{l}-0.14 \\
(0.19)\end{array}$ & $\begin{array}{l}-0.06 \\
(0.24)\end{array}$ & $\begin{array}{l}-0.55 \\
(3.02)\end{array}$ & $\begin{array}{l}-0.26 \\
(0.20)\end{array}$ & $\begin{array}{l}-0.31 \\
(0.21)\end{array}$ \\
\hline WTP (in ‘000 IDR) & $\begin{array}{l}0.02^{* * *} \\
(0.005) \\
\end{array}$ & $\begin{array}{l}0.02^{* * *} \\
(0.005) \\
\end{array}$ & $\begin{array}{c}0.11 \\
(0.12) \\
\end{array}$ & $\begin{array}{l}0.02 * * * \\
(0.005) \\
\end{array}$ & $\begin{array}{l}0.01 * * * \\
(0.004) \\
\end{array}$ \\
\hline $\mathrm{N}$ & 198 & 198 & 198 & 198 & 198 \\
\hline \multicolumn{6}{|c|}{$\begin{array}{l}\text { Column (1) shows AME for the number of tree seedlings planted with control variables; column (2) reports AME for the number of } \\
\text { tree seedlings alive with control variables; column (3) shows AME for the number of tree seedlings obtained and planted in addition } \\
\text { with control variables; column (4) shows AME for the number of tree seedlings planted in oil palm and rubber plantations and fallow } \\
\text { land with control variables; column (5) reports AME for the number of tree seedlings alive planted in oil palm and rubber plantations } \\
\text { and fallow land with control variables; } \\
\text { Negative binomial regressions were applied. Besides the control variables, a pre-treatment dependent baseline variable was } \\
\text { included in all model specifications. } \\
\text { Control variables include age, education, whether the farmer was part of the transmigration program, a dummy if the farmer has } \\
\text { planted trees in his/her oil palm plantation in the last } 12 \text { months, the baseline dependent variable, land owned (in ha), the distance } \\
\text { from the nearest oil palm plantation to the house of the farmer (in km), and three different tree bundles offered. } \\
\text { Standard errors clustered at village level in parentheses; } \\
{ }^{*} p<0.1,{ }^{* *} p<0.05,{ }^{* * *} p<0.01\end{array}$} \\
\hline
\end{tabular}

Table A2.9: AME for sub-sample T2 


\title{
3 Environmental concern and pro-environmental behavior among residents in an oil palm cultivating hotspot $^{14}$
}

\begin{abstract}
Oil palm is the most significant boom crop in Southeast Asia and associated with tremendous negative environmental effects. These environmental effects can influence the environmental concern (EC) and pro-environmental behavior (PEB) of the local population in different ways. While various research has investigated rural-urban differences for EC and PEB, evidence is missing for societies in the Global South where rural and urban populations face similar environmental problems. This paper addresses the questions of what influences EC and PEB of residents living in a hotspot for oil palm cultivation with a special focus on the geographical residence in Indonesia. Our results from OLS regressions show that overall, rural residents directly involved in oil palm cultivation tend to be more concerned than the urban respondents. This is true for general EC, as well as for the oil palm-related EC, which points towards oil palm farmers being aware of the environmental repercussions of oil palm plantations. We also find that connectedness with nature, connectedness with oil palms, and preferences for homogenized landscapes are important factors that are correlated with EC. PEB is measured in terms of donations made to a local environmental organization. Our results, first of all, show strong positive correlations between EC measures and PEB. Furthermore, results reveal that rural respondents make significantly higher donations. In addition, a higher connectedness with oil palms decreases donations among our respondents, while the hours participated in other environmental activities correlate positively with donations.
\end{abstract}

Keywords: environmental concern, pro-environmental behavior, rural-urban gap, inverse hyperbolic sine transformation

\footnotetext{
${ }^{14}$ This chapter has been submitted to Land Use Policy and is co-authored by Edi Edison (EE) and Meike Wollni (MW). Karina Brenneis (KB) conceptualized the research idea, designed the experiment, collected, analyzed, interpreted the data, and wrote the manuscript. EE assisted in revising the manuscript. MW commented at different stages of the research and helped with the revision of the manuscript.
}

Funding: This study was funded by the Deutsche Forschungsgemeinschaft (DFG, German Research Foundation) - grant number 192626868 - in the framework of the collaborative German-Indonesian research project CRC 990. 


\subsection{Introduction}

Oil palm is the most significant boom crop in Southeast Asia and is associated with a large-scale agrarian transformation (Hall 2009). Besides large-scale commercial investments in oil palm plantations, increasing numbers of smallholder farmers are involved in the sector (Euler et al. 2016). In Indonesia, the world's biggest producer of palm oil (Rist et al. 2010; Gatto et al. 2015), small-scale farmers account for about 40 percent of the land cultivated with oil palms (Euler et al. 2016). While this development has brought economic benefits for whole regions (Sjahza and Asmit 2019), it has also had tremendous negative environmental effects (Koh and Wilcove 2008; Obidzinski et al. 2012; Lee et al. 2014). Negative environmental effects experienced by the local population include water pollution from agrochemical use and air pollution from fires when land is cleared for new oil palm plantations. These environmental repercussions do not only affect the rural population, e.g. small-scale oil palm farmers who are directly involved in oil palm cultivation, but also the urban residents who are not necessarily involved in the oil palm sector (Varkkey 2013).

This study addresses two main research questions. First, it aims to understand the drivers of environmental concern ${ }^{15}(\mathrm{EC})$ in a setting characterized by rapid land use transformation, particularly focusing on rural-urban differences in concern. Secondly, it investigates the links between the place of residence, environmental concern, and pro-environmental behavior ${ }^{16}$ (PEB). A better understanding of environmental concern and pro-environmental behavior and their variation in space can inform the development of more targeted policy and outreach measures to support sustainable land-use transformations.

Previous research has found a weak rural-urban gap in EC, but with mixed results regarding who is more concerned about the environment (Huddart-Kennedy et al. 2009; Yu 2014; Mobley 2016). Different theories have been suggested to explain the gap. The environmental deprivation theory (Bogner and Wiseman 1997), for example, claims that exposure to environmental degradation increases EC, providing an explanation for urban residents usually having higher EC. The extractivecommodity theory (Jones et al. 1999) states that rural residents possess a more utilitarian view of the environment and hence, are less concerned (Tremblay and Dunlap 1978; Lowe and Pinhey 1982; Jones et al. 1999). This also includes those rural residents that are not employed in natural-resource extractive industries, such as agriculture, due to a common culture (Tremblay and Dunlap 1978). In

\footnotetext{
${ }^{15}$ Definition of environmental concern: "Environmental concern has been treated as an evaluation of, or an attitude towards facts, one's own behaviour, or others' behaviour with consequences for the environment (Weigel, 1983; Ajzen,1989; Sjöberg, 1989; Takala, 1991). It seems then as if environmental concern may refer to both a specific attitude directly determining intentions, or more broadly to a general attitude or value orientation." (Fransson and Gärling 1999)

16 Definition of pro-environmental behavior: "By 'pro-environmental behaviour', we simply mean behaviour that consciously seeks to minimize the negative impact of one 's actions on the natural and built world [...]." (Kollmuss and Agyeman 2002)
} 
contrast to the frequent finding that urban residents are more environmentally concerned, Berenguer et al. (2005) found that for specific conservation issues, rural residents tend to be more concerned than urban residents. In a recent study, Sharp and Adua (2009) measure EC along a rural-urban gradient in Ohio, US, and found that besides geographical residence, social proximity to agriculture has a positive influence on EC. Literature that specifically focuses on EC in developing countries is scarce, and mostly confined to cross-national comparisons of EC (Rauwald and Moore 2002; Schultz et al. 2005; Watson and Halse 2005) or focusing on a particular case study in either urban (e.g. Khan et al. 2012) or rural settings (e.g. Baptiste and Nordenstam 2009).

Regarding PEB, a variety of different types of behavior have been analyzed in the literature including, e.g. recycling, buying organic food, political activities, and donating money (Shang and Croson 2009; Raihani et al. 2013). Only a few of these studies have specifically looked at rural-urban differences, finding mixed results regarding who engages more in PEB (Berenguer et al. 2005; Saphores et al. 2006; Huddart-Kennedy et al. 2009; Yao 2015). Yao (2015), for example, analyses PEB, defined as charitable donations, in the US, and finds that urban residents tend to donate more than rural residents. In contrast, Berenguer et al. (2005) found that rural residents in Spain engaged slightly more in PEB compared to urban residents.

Most studies on rural-urban differences in PEB are, however, conducted in industrialized countries, and hence, empirical evidence for developing countries is scarce. An exception is a recent study in Zambia that analyzed various types of PEB (waste minimization, re-use and recycling of garbage, no open burning of garbage, use of waste bins, and no dumping in undesignated areas) and found significant differences between rural and urban residents (Chileshe and Sampa Moonga 2019). For most types of PEB, urban residents showed higher engagement levels compared to rural residents, which may be related to differences in perceived barriers, such as lack of capital, information, and political will (Chileshe and Sampa Moonga 2019). However, like most studies cited above (except for donations in industrialized nations (Shang and Croson 2009; Raihani et al. 2013)), the study relies on self-reported behavior, which tends to be less reliable than actual observed behavior (Hamilton 1985; Corral-Verdugo 1997).

Our study was implemented in Jambi Province, Indonesia, and thus adds to the scarce literature on rural-urban differences in EC and PEB in a developing country context. We focus on rural and urban residents living in a hotspot of oil palm cultivation and thus being exposed to the same type of environmental problems. While rural residents in our study area are actively involved in oil palm cultivation, urban residents are typically not. Nonetheless, they benefit from the economic development of the oil palm boom and suffer from the environmental consequences, which provides a unique setting to study rural-urban differences in EC and PEB. In our study, we use a donation game 
with real payoffs to measure PEB. This provides us with a consistent measure that can be applied to rural and urban residents alike, irrespective of the heterogeneous barriers and opportunities they face to engage in actual PEB. PEB is then measured as the amount donated to a local environmental organization that supports forest restoration, wildlife conservation, and sustainable local development in the research area.

The rest of the paper is organized as follows: The next section gives background information on the development of oil palm cultivation and the effects on the local population in Jambi, Indonesia. Section 3 explains the conceptualization and measurement of the main variables used in our study and provides information about the study context, data, and statistical framework. Section 4 presents the descriptive statistics and describes the construction of the EC measures. Section 5 shows the results, and section 6 discusses them and concludes.

\subsection{Oil palm cultivation in Indonesia and its effects on the local population}

Indonesia has been the world's biggest producer and exporter of palm oil since 2008 (Rist et al. 2010; Gatto et al. 2015) and has expanded the area under oil palm cultivation by another two million hectares between 2008 and 2018 (FAOSTAT, 2020). The province of Jambi on the island of Sumatra is a hotspot for biodiversity and oil palm cultivation with an increasing area under cultivation. Most of the oil palm plantations in Jambi have been established on former forest land (Koh and Wilcove 2008; Schwarze et al. 2015) as well as on land that was used for rubber and food crops (Schwarze et al. 2015). It could be shown that economic factors such as the worldwide increasing demand for palm oil (DeFries et al. 2010; Rulli et al. 2019), increasing product prices (Wheeler et al. 2013), and policies of the Indonesian government are associated with land clearing (Fitzherbert et al. 2008; Rist et al. 2010; Euler et al. 2016). In addition, the expansion of oil palm plantations has been associated with immigration and urbanization in the region (Budidarsono et al. 2013). Moreover, urban growth itself is positively correlated with deforestation (DeFries et al. 2010).

The expansion of oil palm monocultures has led to tremendous negative environmental effects, for example, through the loss of forest areas, decrease in biodiversity, and water and air pollution (Feintrenie et al. 2010; Gibson et al. 2011; Merten et al. 2016; Austin et al. 2017; Dislich et al. 2017; Santika et al. 2019), an increase in greenhouse gas emissions (Fargione et al. 2008) as well as a rapid land-use transition (Villamor et al. 2015) directly and indirectly affecting the local population. With relatively high profitability and low labor costs, the expansion of oil palm plantations nowadays is more driven by economic profitability than by environmental suitability (Sayer et al. 2012), resulting in high 
opportunity costs of protecting forests and peatlands. Due to the common management practices applied in the oil palm sector that lead to water and air pollution (Feintrenie et al. 2010; Gibson et al. 2011; Merten et al. 2016; Austin et al. 2017; Dislich et al. 2017; Santika et al. 2019), public health, not only of farmers but also of others in the region, including in cities, is negatively affected. An example of this is the expansion of oil palm plantations on peatlands (Koh et al. 2011; Carlson et al. 2012; Stibig et al. 2014; Naylor et al. 2019) being responsible for environmental damages, especially in dry years (Naylor et al. 2019). Scholars have shown that 90 percent of transboundary haze in the Southern parts of South East Asia is coming from peatland fires (Varkkey 2013).

With regards to economic benefits, oil palm expansion has led to an increase in incomes and an enhancement of the living standards of farmers and their communities (Gatto et al. 2015). Furthermore, the oil palm sector has also become an important source of income for non-farm households working as hired laborers in the oil palm plantations (Bou Dib et al. 2018). Accordingly, the oil palm sector has generated substantial job opportunities and income sources in rural areas (Pacheco et al. 2017). As oil palm cultivation has overall lower labor requirements than alternative cash crops like rubber, oil palm farmers can manage larger areas of oil palms or alternatively, use the saved time to engage in off-farm activities (Euler et al. 2017). Higher rural incomes are usually spent in the cities nearby, thus having a positive effect on the local economy. Furthermore, public and/or private sector investments in infrastructure (e.g. roads, education, and health) have augmented in the course of the oil palm boom, stimulating development in the region and hence, benefiting rural and urban residents alike (Budidarsono et al. 2013, Pacheco et al. 2017, Kubitza et al. 2018). This might ultimately also increase employment opportunities in the cities (Budidarsono et al. 2013).

\subsection{Empirical data and estimation framework}

\subsubsection{Study area and sampling}

Our research was implemented in Jambi Province, Sumatra, Indonesia. The island of Sumatra is a hotspot for biodiversity with an increasing area under monoculture crops like rubber and oil palm. About 75 percent of the land in Jambi Province under oil palm cultivation is managed by small-scale farmers (BPS-Statistics Indonesia 2019). 

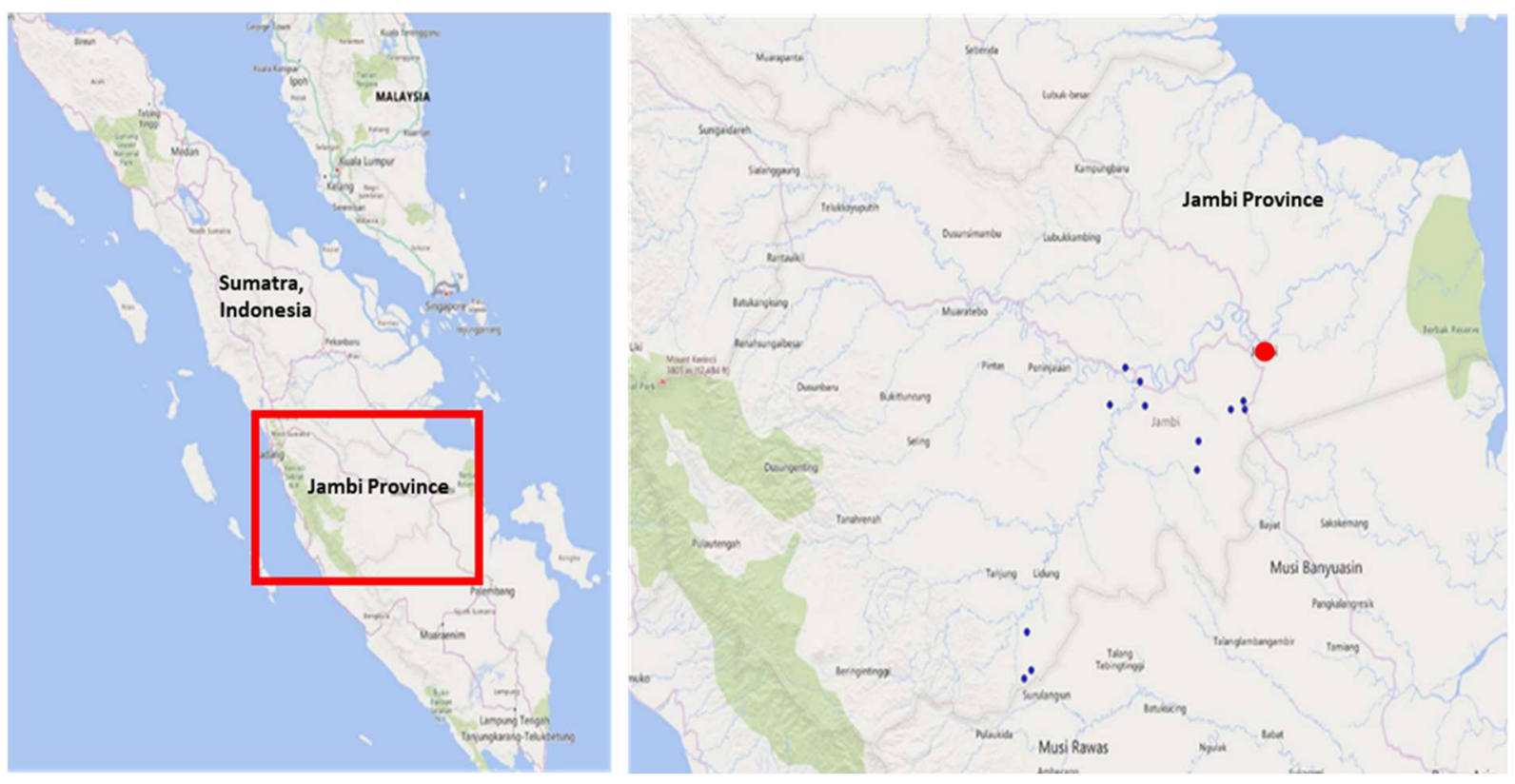

Figure 3.1: Research area: Jambi, Sumatra, Indonesia: On the left photo you can see the map of the island of Sumatra, Indonesia; On the right photo you can see Jambi Province on Sumatra, Indonesia (The blue dots mark the villages where the interviews were conducted and the orange dot marks Jambi City were we also conducted our interviews.)

Our research was conducted in the lowland region of Jambi Province (figure 3.1). We interviewed oil palm farmers in three oil palm growing districts in Jambi Province, namely Muaro Jambi, Batanghari, and Sarolangun where the area under oil palm cultivation has expanded the most between 1995 and 2011 (Euler et al. 2016). A total of 12 villages were selected where 40 oil palm farmers per village were randomly selected and interviewed. In four of these villages, we were only able to interview 20-24 oil palm farmers due to logistical problems. A total of 408 rural oil palm farmers were interviewed in total. To reflect the actual farmers' composition in Jambi, we included transmigrant as well as local villages in our sample. The transmigration program was initiated by the Indonesian government in the 1980s and relocated families from Java to Sumatra and other islands. Each of the families was given two to three hectares of land and support from the government to cultivate cash crops (oil palms and rubber) (Gatto et al. 2015).

For the urban setting, we randomly chose six districts out of a total of 11 districts in Jambi City (about 500,000 inhabitants). In each of the chosen districts, we randomly selected one or two sub-districts, depending on the district's size, resulting in a total of 10 sub-districts in which the survey was implemented. In each sub-district between 32 and 37 households were randomly selected to participate in our survey. We ended up with a total of 349 respondents for the urban setting. Hence, our total sample consisted of 757 respondents. The data analyzed in this paper was collected with a standardized questionnaire. For the data collection, 10 local enumerators were trained. These 10 enumerators conducted the interviews in the villages as well as in Jambi City. 


\subsubsection{Conceptualizing and measuring PEB}

Previous literature has usually assessed PEB based on self-reported measures. Although some studies have found a correlation between self-reported behavior and actual observed behavior (Fujii et al. 1985), others have only found low correlations, typically showing that actual observed behavior is more reliable (Hamilton 1985; Corral-Verdugo 1997). For many types of PEB, actual participation will depend on existing barriers and opportunities. Derksen and Gartrell (1993), for example, showed that recycling behavior among rural and urban residents strongly depended on whether residents had access to recycling options. To overcome some of these challenges associated with the measurement of PEB, and ensure that both rural, as well as urban residents, have access to the PEB, we implemented a donation game with real payoffs and used the amount donated to a local environmental organization as a measure of PEB. Harapan Rainforest was chosen as the recipient of donations, a conservation initiative located in Jambi Province that acquired the rights to manage almost 1,000 $\mathrm{km}^{2}$ of forest land providing a model for forest restoration, wildlife conservation, and sustainable local development ${ }^{17}$.

The donation game was designed as a dictator game which is commonly used in the literature to measure motivations for human behavior (Eckel et al. 1996; Hoffman et al. 1996; Bekkers 2007). Our game consisted of two players: the recipient (local environmental organization) and the allocator (respondent). The allocator was given an endowment that he/she had to split between himself/herself and the recipient. The recipient did not have any power within the game, and could only accept the distribution made by the allocator. Once the allocator had made his/her decision, the allocator received his/her share of the endowment that he/she had decided to keep. The amount that he/she had decided to donate was deposited in an envelope and later given to the recipient (Bekkers 2007; Bardsley 2008).

The donation game was embedded in the standardized questionnaire for the respondents. At the start of the game, each respondent received 35,000 IDR (2.48 USD $\left.{ }^{18}\right)$ in the form of a voucher to be redeemed at a local store. The enumerator provided the respondent with information about the work of Harapan Rainforest after which he/she had some time to think about how much money to keep and how much money to give to Harapan Rainforest. The respondent then noted the amount to keep and the amount to give to Harapan Rainforest on a piece of paper and returned it to the enumerator; after that, the interview continued. Participants did not receive any information about the other participants or their decisions, neither during nor after the interview.

\footnotetext{
${ }^{17}$ Information retrieved from BirdLife International: http://www.birdlife.org/

${ }^{18}$ The money was converted from IDR to USD using the conversion rate from June 2019.
} 
While the donation game with real payoffs has the advantage of being incentive-compatible, one limitation in our setting is that anonymity could not be fully guaranteed, because the research assistant was able to observe the participant's allocation. Previous experimental research has shown that allocators tend to give more to the recipient when anonymity cannot be guaranteed (Franzen and Pointner 2012). Another study from Winking (2014) found that missing privacy, on the one hand, increased the shame that allocators felt, but on the other hand, after removing this specific cost, had a minimal effect on the allocator's actual behavior. While the amounts donated in our study may thus be slightly overestimated, we do not expect that this introduces a bias between rural and urban respondents, because all participants faced the same experimental conditions.

\subsubsection{Measuring EC}

Our measure of EC is based on the New Environmental Paradigm (NEP) Scale (Dunlap et al. 2003). The scale is built on the Schwartz norm-activation model of altruism that has been used to explain altruistic behavior (Kollmuss and Agyeman 2002). The NEP Scale includes a spectrum of beliefs and values that reflect a pro-environmental orientation and thus has become a widely used measure of EC (Dunlap et al. 2003). The NEP Scale consists of a total of 15 items (Dunlap et al. 2003), each of them is rated on a scale from $1=$ strongly agree to $5=$ strongly disagree.

We also obtained a measure for EC adapted to our specific oil palm case. For this, we included a scale with items specific to oil palm-related EC adapted from Dutcher et al. (2007) and Romero et al. (2019). Similar to the NEP Scale, each item of the specific oil palm concern is rated on a five-point Likert Scale between one and five where $1=$ strongly agree and $5=$ strongly disagree ${ }^{19}$.

\subsubsection{Measuring nature connectedness and social proximity to agriculture}

Previous research has shown that if people feel more connected with nature, they have a higher EC and are less likely to engage in behaviors that harm the environment (Dutcher et al. 2007; Verges and Duffy 2010; Mayer and Frantz 2010; Arendt and Matthes 2016). To measure connectedness with nature, we used the Other in the self (OIS) scale developed by Aron et al. (1992). This scale measures how close one feels to nature through seven diagrams, each diagram consisting of two circles (nature

\footnotetext{
${ }^{19}$ The items for the specific oil palm-related EC can be found in section 3.4.2 Construction of EC measures.
} 
and self). Each diagram differs from the other, starting from having the two circles separated (no connection between self and nature) up to where the two circles in the last diagram are almost one (a very strong connection between self and nature) (see figure A3.1). A higher number along the scale reflects a higher connectedness with nature, whereas a lower number on the scale reflects a lower connectedness with nature. In addition, we obtained a measure for landscape preferences, where respondents indicated which landscape they prefer to live in based on pictures. Previous research has shown that preferences for different landscapes are associated with EC (Kaltenborn and Bjerke 2002). We included three different landscape photos: oil palm monocultures, agroforest, and rainforest, where the latter two represent diverse landscapes. Based on the responses, we created a dummy variable reflecting the preferences to live in more diverse landscapes $(=1)$ versus more homogeneous landscapes $(=0)$ for our analysis.

Besides nature connectedness and landscape preferences, literature has shown that social proximity to agriculture has a potential influence on EC and PEB (Sharp and Adua 2009). Hence, we included two measures in our study to reflect social proximity to agriculture. The first one is socialization, which measures the years a respondent has lived in a village/city between the age of 0 and 18 . The second one is another OIS scale, adapted to our specific setting. This OIS oil palm scale measures connectedness with oil palms. The two circles used for the OIS, in this case, represent oil palms and the self. We expect that in our particular study context, a setting with intense oil palm cultivation, a higher connectedness with oil palms is associated with lower EC.

\subsubsection{Econometric framework}

In the first part of our analysis, we estimate the association between place of residence and EC; the model is specified as follows:

$y_{i}=\beta_{0}+\beta_{1}$ city $_{i}+\beta_{2} N C_{i}+\beta_{3} S P A_{i}+\beta_{4} X_{i}+\varepsilon_{i}$

where $y_{i}$ is $\mathrm{EC}$ (general or oil palm-specific EC) of respondent $\mathrm{i}$. City $\mathrm{i}_{\mathrm{i}}$ is a dummy that equals 1 if the respondent has his or her current residence in the city, and a value of 0 if the respondent has his or her current residence in a village. $N C_{i}$ contains variables related to nature connectedness; and $S P A_{i}$ variables related to social proximity to agriculture. $X_{i}$ is a vector of household sociodemographics. In the regression on oil-palm-related EC, we further include the general EC as a covariate to capture correlations between general EC and more specific EC (Stern et al. 1995). The $\beta s$ are parameters to be estimated, and $\varepsilon_{i}$ is a random error term. The model is estimated using OLS. 
The second part of the analysis is dedicated to PEB, where we analyze the binary decision to donate as well as the amount donated to a local environmental organization. The model is specified as follows:

$y_{i}=\beta_{0}+\beta_{1}$ city $_{i}+\beta_{2} Z_{i}+\beta_{3} N C_{i}+\beta_{4} S P A_{i}+\beta_{5} X_{i}+\varepsilon_{i}$

where $y_{i}$ is the outcome variable - either the binary decision or the amount donated - by respondent $\mathrm{i}$, and $\mathrm{Z}_{\mathrm{i}}$ contains $\mathrm{EC}$ measures. City $\mathrm{i}_{i}, \mathrm{NC}_{\mathrm{i}}$, and $S P \mathrm{~A}_{\mathrm{i}}$ are defined as in equation (1) and $\mathrm{X}_{\mathrm{i}}$ contains similar household sociodemographics. In addition, we include a covariate on self-reported PEB. The binary decision to donate is estimated using a probit model (Long 1997).

For the continuous outcome variable, the amount donated, we apply an inverse hyperbolic sine (IHS) transformation to the outcome variable (Bellemare and Wichman 2019) to accommodate nonnormality. The IHS transformation has two important characteristics: (1) the transformation has similar properties as the log transformation but (2) it allows to keep zero-valued observations, unlike the log transformation. In our data, we have about 18 percent zero-valued observations because some respondents chose not to donate at all. For the continuous outcome variable $y$ the IHS transformation can be written as follows:

$\tilde{y}=\operatorname{arcsinh}(y)=\log \left(y+\sqrt{y^{2}+1}\right)$

After the estimation, we follow Bellemare and Wichman (2019) and calculate elasticities for the respective continuous variables of interest. Standard errors are obtained applying the delta method for exact values. For the dummy variables, we calculate semi-elasticities.

As a robustness check, we also applied a double-hurdle model, which assumes that the donation decision follows a two-step process. In the first step, the respondent's decision to donate is estimated using a probit model. In the second step, the decision of how much to donate is estimated using a logtransformed OLS regression (Manning and Mullahy 2001). The results can be found in the appendix (tables $\mathrm{A} 1$ and $\mathrm{A} 2$ ).

\subsection{Empirical data}

\subsubsection{Sample overview}

Table 3.1 shows descriptive statistics for the sociodemographic variables. Column (1) presents data for the full sample, columns (2) and (3) for urban and rural residents respectively. Column (4) shows pvalues of mean difference tests for the two sub-samples. We find significant differences between urban and rural residents with respect to the age of the household head and the number of household 
Chapter 3: Environmental concern and pro-environmental behavior among residents in an oil palm cultivating hotspot

members, although the latter difference is rather small. Regarding age, rural household heads are almost 3 years younger on average compared to urban household heads. The descriptives further show that around 90 percent of household heads in our sample have finished primary or secondary school. Education tends to be somewhat higher in the urban sample, but not significantly so. The asset index, as a proxy for wealth, also does not differ significantly between the two sub-samples.

\begin{tabular}{|c|c|c|c|c|}
\hline & (1) & (2) & (3) & (4) \\
\hline & Mean estimates & City & Village & City = Village \\
\hline \multicolumn{5}{|l|}{ Sociodemographics } \\
\hline $\begin{array}{l}\text { Age of household } \\
\text { head }\end{array}$ & $\begin{array}{c}49.24 \\
(12.08)\end{array}$ & $\begin{array}{c}47.71 \\
(13.08)\end{array}$ & $\begin{array}{c}50.54 \\
(11.00)\end{array}$ & $0.01 * *$ \\
\hline $\begin{array}{l}\text { Gender of household } \\
\text { head: } \\
1=\text { female } \\
0=\text { male }\end{array}$ & $\begin{array}{l}8.98 \% \\
91.02 \%\end{array}$ & $\begin{array}{l}12.61 \% \\
87.39 \%\end{array}$ & $\begin{array}{l}5.88 \% \\
94.12 \%\end{array}$ & 0.11 \\
\hline $\begin{array}{l}\text { Education of } \\
\text { household head in } \\
\text { years }\end{array}$ & $\begin{array}{c}9.99 \\
(4.02)\end{array}$ & $\begin{array}{l}10.54 \\
(3.62)\end{array}$ & $\begin{array}{c}9.53 \\
(4.28)\end{array}$ & 0.19 \\
\hline $\begin{array}{l}\text { Number of } \\
\text { household members }\end{array}$ & $\begin{array}{c}4.03 \\
(1.45)\end{array}$ & $\begin{array}{c}4.31 \\
(1.57)\end{array}$ & $\begin{array}{c}3.80 \\
(1.30)\end{array}$ & $0.02 * *$ \\
\hline Asset index ${ }^{1}$ & $\begin{array}{c}-7.37 e-09 \\
(0.72)\end{array}$ & $\begin{array}{l}-0.20 \\
(0.65)\end{array}$ & $\begin{array}{c}0.17 \\
(0.73)\end{array}$ & 0.16 \\
\hline $\begin{array}{l}\text { Place of residence (in } \\
\text { percent): } \\
1 \text { = Village } \\
0=\text { City }\end{array}$ & 100 & 46.10 & 53.90 & - \\
\hline $\begin{array}{l}\text { Household migrated } \\
\text { to current place of } \\
\text { living } \\
1=\text { yes } \\
0=\text { no }\end{array}$ & 56.27 & 44.13 & 66.67 & $0.06 *$ \\
\hline $\mathrm{N}$ & 757 & 349 & 408 & 757 \\
\hline \multicolumn{5}{|c|}{ 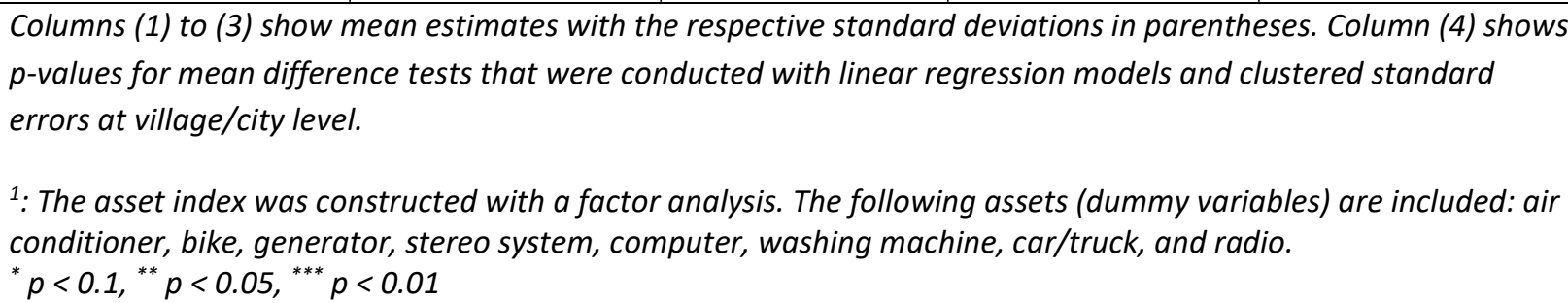 } \\
\hline
\end{tabular}

Table 3.1: Descriptive statistics - sociodemographics

Income portfolios in the research area are quite diverse. About 60 percent of the rural households mentioned that they had at least one more income source besides agriculture. These additional income activities include wage labor on other farms and non-agricultural work of the household head or other household members. Urban households have on average 1.7 income sources. Only two percent of the urban households in our sample are involved somewhere along the oil palm value chain. 
Chapter 3: Environmental concern and pro-environmental behavior among residents in an oil palm cultivating hotspot

Among the rural households, more than 90 percent have a home garden growing fruits and vegetables primarily for self-consumption but also sell the harvest at local markets. In the urban area, where space is more limited than in the rural area, only about 40 percent of the households have a home garden.

Table 3.2 shows the descriptive statistics for nature connectedness and social proximity to agriculture. Regarding social proximity to agriculture, we find that rural respondents feel significantly more connected with oil palms than urban respondents. This is not surprising, since all rural households are engaged in oil palm cultivation, whereas only a few of the urban households are directly in the oil palm value chain. We can further see that rural residents have lived most of their childhood in a village, and urban residents have lived most of their childhood in the city. Rural residents, on average, have only spent 1.5 years in a city during their childhood, suggesting very low rates of urban-rural migration. For urban residents, the average years lived in a village during childhood is somewhat higher with 5.4 years, but still low, indicating that most urban residents grew up in the city.

Regarding nature connectedness, respondents overall feel very connected with nature, indicated by an average score of 5.6 out of a maximum of seven (column 1). Although urban residents have a slightly higher score, the difference between urban and rural households is not statistically significant. Based on our visual assessment of landscape preferences, we find that the majority of households in our sample prefer to live in more diverse landscapes, particularly in a landscape characterized by agroforests. Preferences for homogenized oil palm-dominated landscapes are slightly higher among rural households, but the difference between urban and rural samples is not significant.

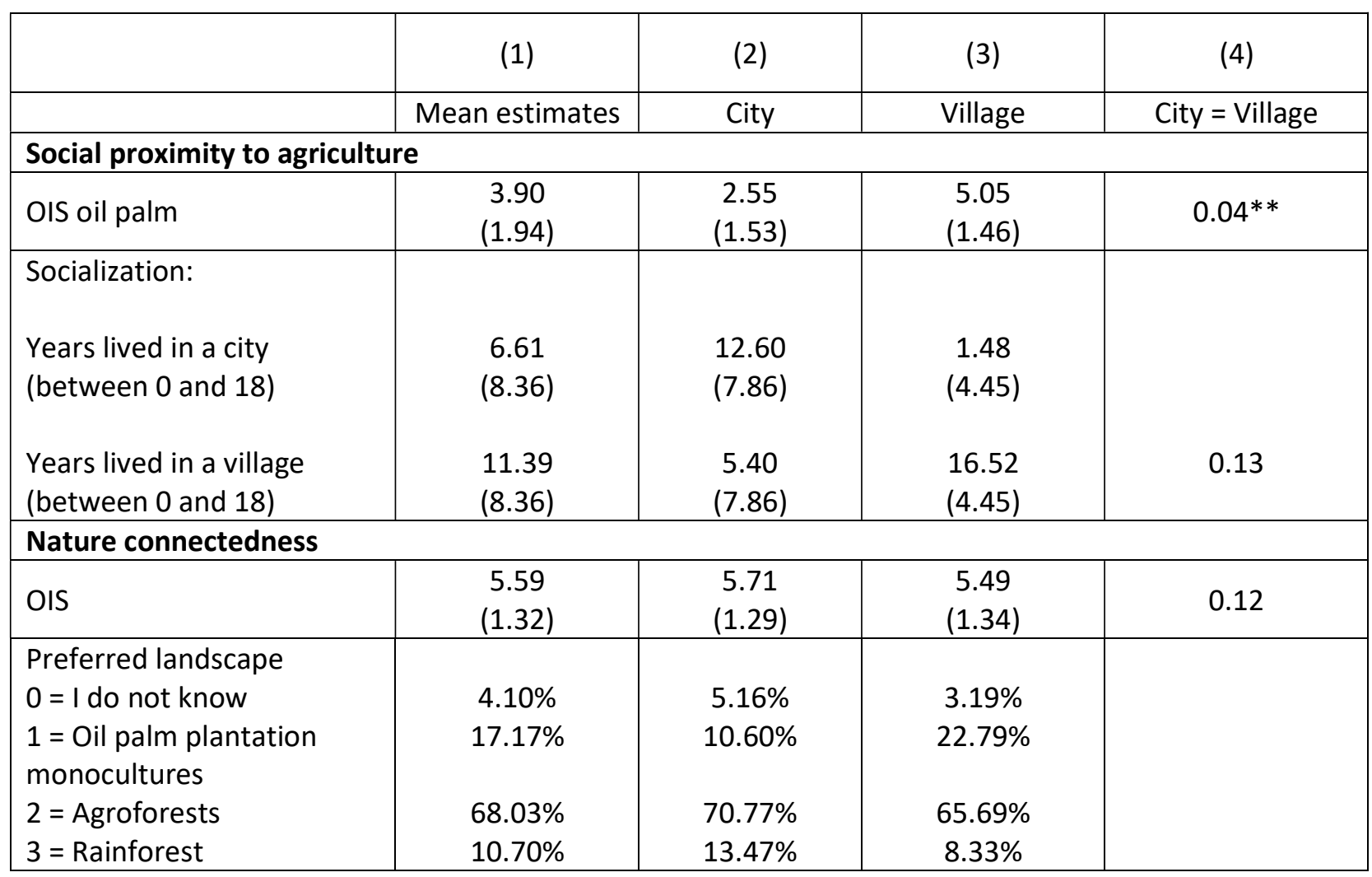




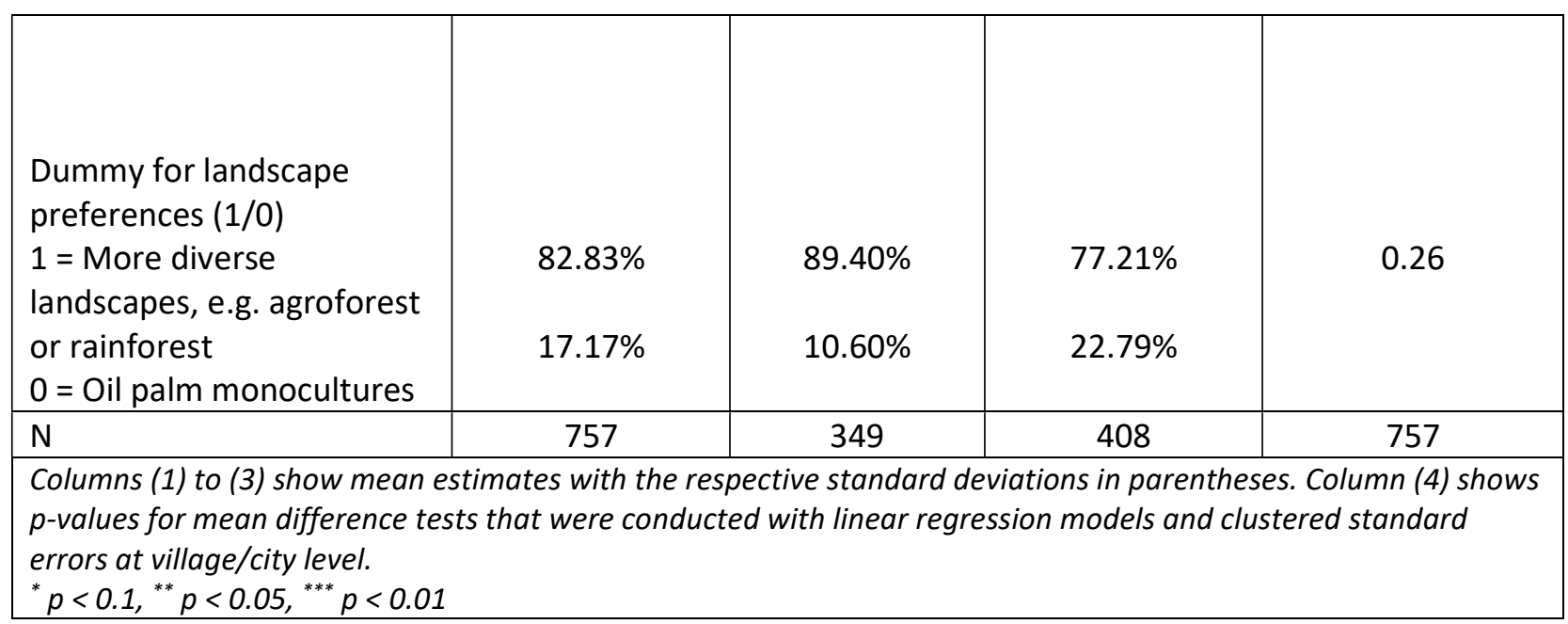

Table 3.2: Descriptive statistics - nature connectedness and social proximity to agriculture

\subsubsection{Construction of EC measures}

Table 3.3 provides an overview of the fifteen items of the NEP scale, which is used to construct the general EC measure. Response categories for each item are given a numerical code between 1 and 5, such that higher values correspond to a stronger EC (note that for odd-numbered items the order is reversed for the construction of the total score so that a higher number reflects a higher concern). With a possible minimum score of 15 and a maximum of 75 , the mean score for the NEP scale in our sample is 47.2. We find that our overall mean seems to arrange itself in the middle compared to other studies that were conducted in industrialized nations: Overall, this mean value lies well within the range of mean values found in other studies, typically conducted in industrialized nations: Berenguer et al. (2005) report a mean value of 50.97 for the rural sample and of 54.47 for the urban sample in Spain. In Huddart-Kennedy et al. (2009), the overall sample mean for urban and rural respondents in Canada is 34.36 .

Following Kotchen and Reiling (2000) and Clark et al. (2003), we combine the NEP items into a unidimensional scale applying factor analysis and use this scale for our analysis. We obtained a Cronbach's Alpha of 0.60 and a Kaiser-Meyer-Olkin (KMO) measure of 0.71 , which is moderate. The item-total correlations for each item (table 3.3, column (3)) demonstrate that all correlations are reasonably good, ranging from a high of 0.45 to a low of 0.18 for 12 of the 15 items. Three items have a relatively low item-total correlation. We follow Khan et al. (2012) and drop these three items (items 4,8 , and 10) leading to a KMO of 0.74 and a Cronbach's Alpha of 0.66 . These results suggest that in our sample the NEP scale (based on 12 items) forms an internally consistent measuring instrument of EC (Kotchen and Reiling 2000). 
Chapter 3: Environmental concern and pro-environmental behavior among residents in an oil palm cultivating hotspot

\begin{tabular}{|c|c|c|c|c|}
\hline & & 1 & 2 & 3 \\
\hline $\begin{array}{c}\text { NEP } \\
\text { number }\end{array}$ & NEP item & Mean & $\begin{array}{l}\text { Standard } \\
\text { deviation }\end{array}$ & $r_{i-t}$ \\
\hline 1 & $\begin{array}{l}\text { We are approaching the limit of the } \\
\text { number of people the earth can } \\
\text { support. }\end{array}$ & 3.56 & 1.08 & 0.32 \\
\hline 2 & $\begin{array}{l}\text { Humans have the right to modify the } \\
\text { natural environment to suit their needs. }\end{array}$ & 2.21 & 1.02 & 0.29 \\
\hline 3 & $\begin{array}{l}\text { When humans interfere with nature it } \\
\text { often produces disastrous } \\
\text { consequences. }\end{array}$ & 3.75 & 0.97 & 0.21 \\
\hline 4 & $\begin{array}{l}\text { Human ingenuity will ensure that people } \\
\text { will be able to continue to live on the } \\
\text { earth. }\end{array}$ & 2.36 & 1.04 & 0.04 \\
\hline 5 & $\begin{array}{l}\text { Humans are severely abusing the } \\
\text { environment. }\end{array}$ & 3.65 & 1.11 & 0.23 \\
\hline 6 & $\begin{array}{l}\text { The earth has plenty of natural } \\
\text { resources if we just learn how to } \\
\text { develop them. }\end{array}$ & 1.86 & 0.92 & 0.41 \\
\hline 7 & $\begin{array}{l}\text { Plants and animals have as much right } \\
\text { as humans to exist. }\end{array}$ & 4.27 & 0.95 & 0.18 \\
\hline 8 & $\begin{array}{l}\text { The balance of nature is strong enough } \\
\text { to cope with the impacts of modern } \\
\text { industrial nations. }\end{array}$ & 2.73 & 1.08 & -0.01 \\
\hline 9 & $\begin{array}{l}\text { Despite our special abilities, humans are } \\
\text { still subject to the laws of nature. }\end{array}$ & 3.97 & 0.88 & 0.22 \\
\hline 10 & $\begin{array}{l}\text { The so-called "ecological crisis" facing } \\
\text { humankind has been greatly } \\
\text { exaggerated. }\end{array}$ & 2.66 & 1.05 & 0.04 \\
\hline 11 & $\begin{array}{l}\text { The earth is like a spaceship with very } \\
\text { limited room and resources. }\end{array}$ & 3.73 & 1.09 & 0.36 \\
\hline 12 & $\begin{array}{l}\text { Humans were meant to rule over the } \\
\text { rest of nature. }\end{array}$ & 2.31 & 1.12 & 0.30 \\
\hline 13 & $\begin{array}{l}\text { The balance of nature is very delicate } \\
\text { and easily upset. }\end{array}$ & 4.02 & 0.78 & 0.45 \\
\hline 14 & $\begin{array}{l}\text { Humans will eventually learn enough } \\
\text { about how nature works to be able to } \\
\text { control it. }\end{array}$ & 2.15 & 0.86 & 0.19 \\
\hline 15 & $\begin{array}{l}\text { If things like climate change continue on } \\
\text { their present course, we will soon } \\
\text { experience a major ecological } \\
\text { catastrophe. }\end{array}$ & 4.00 & 0.86 & 0.40 \\
\hline & $\mathrm{N}$ & \multicolumn{3}{|c|}{757} \\
\hline
\end{tabular}

Table 3.3: Descriptives for NEP scale items

Table 3.4 gives an overview of the five items that are used to construct the oil-palm-specific EC. The coding ( 1 to 5 ) of items number $1,2,3$, and 5 is reversed so that a higher value reflects a higher concern. The Cronbach's Alpha indicates that the internal consistency of the construct is acceptable (table 3.4) 
Chapter 3: Environmental concern and pro-environmental behavior among residents in an oil palm cultivating hotspot

(Moss et al. 1998; Hair et al. 2009). Based on factor analysis, we derive two factors. Items 1, 2, and 3 load strongly on factor one, which thus reflects concern about the negative environmental effects of oil palm cultivation. Items 4 and 5 load strongly on factor two, which thus reflects concern about the lack of local action to reduce the negative environmental effects of oil palm cultivation.

\begin{tabular}{|c|c|c|c|c|c|}
\hline & $\begin{array}{l}\text { Cronbach's Alpha: } 0.57 \\
\text { KMO: } 0.65\end{array}$ & 1 & 2 & 3 & 4 \\
\hline Number & Oil palm concern items & Mean & $\begin{array}{l}\text { Standard } \\
\text { deviation }\end{array}$ & $\begin{array}{c}\text { Factor } \\
\text { loadings: } \\
\text { Factor } 1\end{array}$ & $\begin{array}{l}\text { Factor } \\
\text { loadings: } \\
\text { Factor } 2 \\
\end{array}$ \\
\hline 1 & $\begin{array}{l}\text { Oil palm expansion is increasing fast in } \\
\text { Jambi. More and more area is used for } \\
\text { oil palm plantations. If oil palm } \\
\text { expansion continues at the current } \\
\text { speed, problems of haze and air } \\
\text { pollution will soon become unbearable } \\
\text { in Jambi. }\end{array}$ & 3.49 & 1.08 & 0.68 & \\
\hline 2 & $\begin{array}{l}\text { Oil palm cultivation in Jambi has strong } \\
\text { effects on global environmental } \\
\text { problems. }\end{array}$ & 3.46 & 1.09 & 0.69 & \\
\hline 3 & $\begin{array}{l}\text { The expansion of oil palm will soon lead } \\
\text { to the exhaustion of natural resources in } \\
\text { Jambi. }\end{array}$ & 3.57 & 1.12 & 0.66 & \\
\hline 4 & $\begin{array}{l}\text { People in Indonesia worry too much } \\
\text { about the negative environmental } \\
\text { impact of oil palm cultivation. }\end{array}$ & 2.62 & 1.12 & & 0.59 \\
\hline 5 & $\begin{array}{l}\text { We need to plant more native trees in } \\
\text { Jambi to improve and protect the } \\
\text { environment. }\end{array}$ & 4.31 & 0.89 & & 0.53 \\
\hline & $\mathrm{N}$ & \multicolumn{4}{|c|}{757} \\
\hline
\end{tabular}

Table 3.4: Descriptives for oil palm-related concern items

\subsection{Results}

\subsubsection{Determinants of EC}

Table 3.5 reports the descriptive statistics for the different EC measures. We observe a tendency of rural respondents being more concerned than urban respondents, however, p-values of mean difference tests are just above the 10 percent threshold, and thus not significant according to commonly applied inference thresholds.

\begin{tabular}{|l|c|c|c|c|}
\hline & $(1)$ & $(2)$ & (3) & (4) \\
\hline Environmental concern & Mean estimates & City & Village & City = Village \\
\hline
\end{tabular}


Chapter 3: Environmental concern and pro-environmental behavior among residents in an oil palm cultivating hotspot

\begin{tabular}{|c|c|c|c|c|}
\hline $\begin{array}{l}\text { General EC (12-item NEP } \\
\text { scale) }\end{array}$ & $\begin{array}{c}0.00 \\
(0.83)\end{array}$ & $\begin{array}{l}-0.23 \\
(0.77)\end{array}$ & $\begin{array}{c}0.19 \\
(0.84)\end{array}$ & 0.14 \\
\hline $\begin{array}{l}\text { Concern about the negative } \\
\text { environmental effects of oil } \\
\text { palm cultivation }\end{array}$ & $\begin{array}{c}0.00 \\
(0.83)\end{array}$ & $\begin{array}{l}-0.12 \\
(0.82)\end{array}$ & $\begin{array}{c}0.10 \\
(0.83)\end{array}$ & 0.11 \\
\hline $\begin{array}{l}\text { Concern about the lack of } \\
\text { local action to reduce the } \\
\text { negative environmental } \\
\text { effects of oil palm cultivation }\end{array}$ & $\begin{array}{c}0.00 \\
(0.68)\end{array}$ & $\begin{array}{l}-0.39 \\
(0.69)\end{array}$ & $\begin{array}{c}0.33 \\
(0.46)\end{array}$ & 0.10 \\
\hline $\mathrm{N}$ & 757 & 349 & 408 & 757 \\
\hline \multicolumn{5}{|c|}{$\begin{array}{l}\text { Columns (1) to (3) show mean estimates with the respective standard deviations in parentheses. Column (4) } \\
\text { shows } p \text {-values for mean difference tests that were conducted with linear regression models and clustered } \\
\text { standard errors at village/city level. } \\
{ }^{*} p<0.1,{ }^{* *} p<0.05,{ }^{* * *} p<0.01\end{array}$} \\
\hline
\end{tabular}

Table 3.5: Descriptive statistics - EC

Table 3.6 presents the results of the regression on general EC. The regression results reveal a significant association between place of residence and general EC: living in an urban area is associated with a 0.59-point decrease on the NEP scale, indicating that rural respondents in our sample are more environmentally concerned. As expected, we further find a positive and significant correlation between nature connectedness (OIS nature, preference for diverse landscapes) and general EC. In contrast, social proximity to agriculture as measured by connectedness with oil palms is negatively correlated with general EC.

\begin{tabular}{|c|c|}
\hline & General EC \\
\hline \multicolumn{2}{|l|}{ Sociodemographics } \\
\hline Age of household head & $\begin{array}{l}-0.004 \\
(0.002) \\
\end{array}$ \\
\hline Education of household head (measured in years) & $\begin{array}{c}0.005 \\
(0.008)\end{array}$ \\
\hline Gender of household head (1=female) & $\begin{array}{l}-0.06 \\
(0.10) \\
\end{array}$ \\
\hline Asset index & $\begin{array}{c}0.04 \\
(0.04)\end{array}$ \\
\hline \multicolumn{2}{|l|}{ Place of residence } \\
\hline Place of residence (1=village) & $\begin{array}{c}0.59 * * * \\
(0.09)\end{array}$ \\
\hline Household migrated to current place of living (1=yes) & $\begin{array}{l}0.009 \\
(0.07) \\
\end{array}$ \\
\hline \multicolumn{2}{|l|}{ Social proximity to agriculture } \\
\hline OIS oil palm & $\begin{array}{c}-0.05^{* *} \\
(0.02)\end{array}$ \\
\hline Socialization (Years lived in a village between 0 and 18) & $\begin{array}{c}0.001 \\
(0.005)\end{array}$ \\
\hline \multicolumn{2}{|l|}{ Nature connectedness } \\
\hline OIS nature & $\begin{array}{c}0.08^{* * *} \\
(0.02) \\
\end{array}$ \\
\hline $\begin{array}{l}\text { Preference for diverse landscapes (1=agroforest or } \\
\text { rainforest) }\end{array}$ & $\begin{array}{c}0.30 * * * \\
(0.08)\end{array}$ \\
\hline
\end{tabular}


Chapter 3: Environmental concern and pro-environmental behavior among residents in an oil palm cultivating hotspot

\begin{tabular}{|l|c|}
\hline Constant & $-0.65^{* * *}$ \\
\hline $\mathrm{N}$ & $(0.23)$ \\
\hline $\begin{array}{l}\text { Columns (1) and (2) show estimates from an OLS regression; } \\
\text { Robust standard errors in parentheses; }\end{array}$ \\
${ }^{*} p<0.1,{ }^{* *} p<0.05,{ }^{* * *} p<0.01$
\end{tabular}

Table 3.6: OLS estimates for general EC (12-item NEP scale)

Table 3.7 presents regression results for the two oil palm-related EC measures. Place of residence is significantly associated with both oil palm-related EC measures. Compared to urban respondents, rural respondents have a significantly higher concern about the negative environmental effects of oil palm as well as about the lack of local actions to reduce these negative effects. Regarding the concern about the negative environmental effects of oil palm cultivation, we further find that the nature connectedness variables are positively correlated, whereas oil-palm connectedness is negatively correlated with this specific oil-palm-related concern. These findings are very much in line with the correlates of general EC, which finds further support in the fact that this specific oil-palm-related concern is significantly correlated with general EC (table 3.7 , column 1 ).

\begin{tabular}{|c|c|c|}
\hline Oil palm-related EC & $\begin{array}{l}\text { Column (1) } \\
\text { Concern about the negative } \\
\text { environmental effects of oil } \\
\text { palm cultivation }\end{array}$ & $\begin{array}{l}\text { Column ( } 2 \text { ) } \\
\text { Concern about the lack of local } \\
\text { action to reduce the negative } \\
\text { environmental effects of oil } \\
\text { palm cultivation }\end{array}$ \\
\hline \multicolumn{3}{|l|}{ Sociodemographics } \\
\hline Age of household head & $\begin{array}{l}-0.0006 \\
(0.002)\end{array}$ & $\begin{array}{c}0.002 \\
(0.002)\end{array}$ \\
\hline $\begin{array}{l}\text { Education of household head } \\
\text { (measured in years) }\end{array}$ & $\begin{array}{c}0.01 \\
(0.008)\end{array}$ & $\begin{array}{l}-0.008 \\
(0.006)\end{array}$ \\
\hline $\begin{array}{l}\text { Gender of household head } \\
\text { (1=female) }\end{array}$ & $\begin{array}{l}-0.02 \\
(0.09)\end{array}$ & $\begin{array}{c}0.01 \\
(0.09)\end{array}$ \\
\hline Asset index & $\begin{array}{l}-0.002 \\
(0.04)\end{array}$ & $\begin{array}{l}0.001 \\
(0.03)\end{array}$ \\
\hline \multicolumn{3}{|l|}{ Place of residence } \\
\hline Place of residence (1=village) & $\begin{array}{c}0.25^{* * *} \\
(0.09)\end{array}$ & $\begin{array}{c}0.69 * * * \\
(0.07)\end{array}$ \\
\hline $\begin{array}{l}\text { Household migrated to current } \\
\text { place of living (1=yes) }\end{array}$ & $\begin{array}{c}0.05 \\
(0.06)\end{array}$ & $\begin{array}{l}-0.06 \\
(0.05)\end{array}$ \\
\hline \multicolumn{3}{|l|}{ Social proximity to agriculture } \\
\hline OIS oil palm & $\begin{array}{c}-0.09 * * * \\
(0.02) \\
\end{array}$ & $\begin{array}{c}0.02 \\
(0.01) \\
\end{array}$ \\
\hline $\begin{array}{l}\text { Socialization (Years lived in } \\
\text { village between } 0 \text { and 18) }\end{array}$ & $\begin{array}{c}0.003 \\
(0.005)\end{array}$ & $\begin{array}{l}-0.00008 \\
(0.004) \\
\end{array}$ \\
\hline \multicolumn{3}{|l|}{ Nature connectedness } \\
\hline OIS nature & $\begin{array}{c}0.06^{* * *} \\
(0.02)\end{array}$ & $\begin{array}{l}-0.02 \\
(0.02)\end{array}$ \\
\hline $\begin{array}{l}\text { Preference for diverse } \\
\text { landscapes (1=agroforest or } \\
\text { rainforest) }\end{array}$ & $\begin{array}{l}0.14^{*} \\
(0.08)\end{array}$ & $\begin{array}{l}-0.03 \\
(0.06)\end{array}$ \\
\hline
\end{tabular}


Chapter 3: Environmental concern and pro-environmental behavior among residents in an oil palm cultivating hotspot

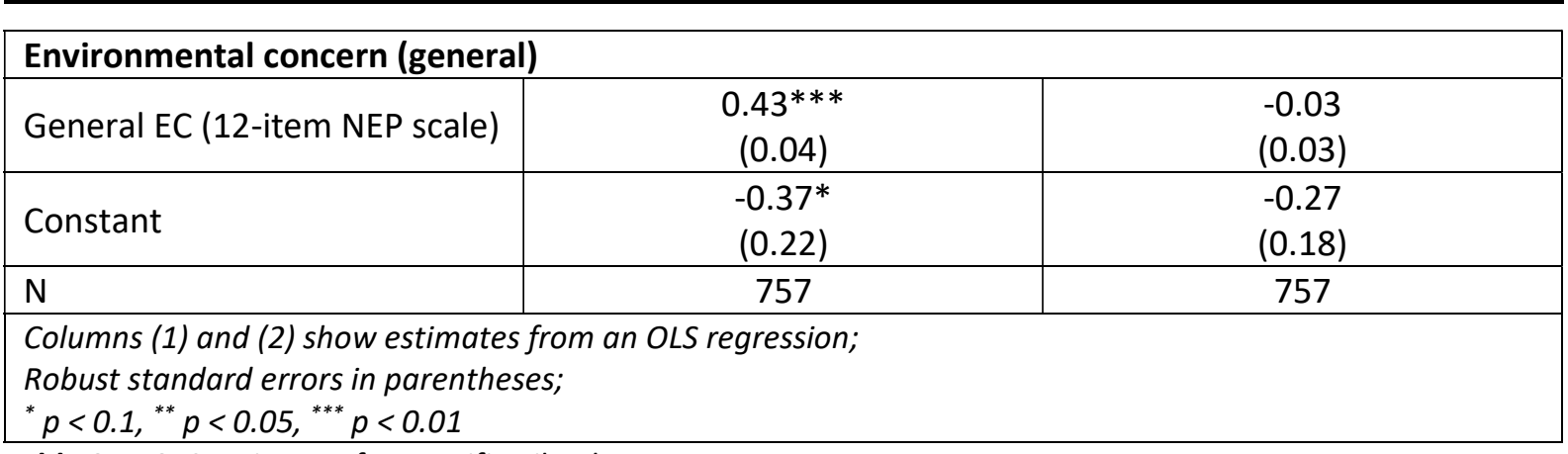

Table 3.7: OLS estimates for specific oil palm concern

\subsubsection{Determinants of PEB}

Table 3.8 shows descriptive statistics of self-reported participation in different types of PEB. Differences are not statistically significant between urban and rural residents, but there is a tendency for urban respondents to engage more hours in the different activities. While urban residents seem to be somewhat more engaged, also in terms of the total hours spent on PEB, we cannot discern whether they are indeed more motivated to undertake PEB or whether they face more opportunities and fewer barriers to engaging.

\begin{tabular}{|c|c|c|c|c|}
\hline & (1) & (2) & (3) & (4) \\
\hline & Mean estimates & City & Village & City $=$ Village \\
\hline \multicolumn{5}{|l|}{ Self-reported PEB } \\
\hline Hours participated in cleaning & $\begin{array}{c}15.41 \\
(39.43)\end{array}$ & $\begin{array}{c}20.30 \\
(51.23)\end{array}$ & $\begin{array}{c}11.22 \\
(24.62)\end{array}$ & 0.29 \\
\hline $\begin{array}{l}\text { Hours participated in } \\
\text { wastewater management }\end{array}$ & $\begin{array}{c}0.42 \\
(7.29)\end{array}$ & $\begin{array}{c}0.55 \\
(10.28)\end{array}$ & $\begin{array}{c}0.31 \\
(2.88)\end{array}$ & 0.41 \\
\hline $\begin{array}{l}\text { Hours participated in recycling } \\
\text { garbage }\end{array}$ & $\begin{array}{l}0.003 \\
(0.07)\end{array}$ & $\begin{array}{c}0.00 \\
(0.00)\end{array}$ & $\begin{array}{l}0.005 \\
(0.10)\end{array}$ & 0.52 \\
\hline $\begin{array}{l}\text { Hours participated in planting } \\
\text { trees/other plants }\end{array}$ & $\begin{array}{c}0.28 \\
(3.68)\end{array}$ & $\begin{array}{c}0.56 \\
(5.39)\end{array}$ & $\begin{array}{c}0.05 \\
(0.40)\end{array}$ & 0.47 \\
\hline $\begin{array}{l}\text { Hours participated in } \\
\text { environmental activities } \\
\text { within the last } 12 \text { months } \\
\text { (sum) }\end{array}$ & $\begin{array}{c}16.11 \\
(40.93)\end{array}$ & $\begin{array}{c}21.41 \\
(53.35)\end{array}$ & $\begin{array}{c}11.58 \\
(25.19)\end{array}$ & 0.30 \\
\hline $\mathrm{N}$ & 757 & 349 & 408 & 757 \\
\hline \multicolumn{5}{|c|}{$\begin{array}{l}\text { Columns (1) to (3) show mean estimates with the respective standard deviations in parentheses. Column (4) } \\
\text { shows } p \text {-values for mean difference tests that were conducted with linear regression models and clustered } \\
\text { standard errors at village/city level. } \\
{ }^{*} p<0.1,{ }^{* *} p<0.05,{ }^{* * *} p<0.01\end{array}$} \\
\hline
\end{tabular}

Table 3.8: Descriptive statistics - self-reported PEBs

As described above, we, therefore, used a donation game to elicit engagement in a PEB that is accessible to both urban and rural respondents alike. Table 3.9 provides descriptive statistics of the 
Chapter 3: Environmental concern and pro-environmental behavior among residents in an oil palm cultivating hotspot

donation decision. Overall, more than three-quarters of the respondents decided to donate, with an average amount of 19.375 IDR (1.37 USD $\left.{ }^{20}\right)$. We can further see that a significantly larger percentage of the rural sample decides to donate, compared to the urban sample, and that the amount donated is significantly larger.

\begin{tabular}{|c|c|c|c|}
\hline $\begin{array}{l}\text { Donation to Harapan } \\
1=\text { yes } \\
0=\text { no }\end{array}$ & \multicolumn{2}{|c|}{$\begin{array}{l}82.30 \% \\
17.70 \%\end{array}$} & \\
\hline Amount donated to Harapan (in IDR) & \multicolumn{2}{|c|}{$\begin{array}{c}19,375 \\
(14.568)\end{array}$} & \\
\hline $\mathrm{N}$ & \multicolumn{2}{|c|}{757} & \\
\hline & City & Village & City =Village \\
\hline & $(1)$ & (2) & (3) \\
\hline $\begin{array}{l}\text { Donation to Harapan (percentage) } \\
\begin{array}{l}1=\text { yes } \\
0=\text { no }\end{array}\end{array}$ & $\begin{array}{l}77.94 \\
22.06\end{array}$ & $\begin{array}{l}86.03 \\
13.97\end{array}$ & $0.01 * *$ \\
\hline Amount donated to Harapan (in IDR) & $\begin{array}{c}15.616 \\
(14.129)\end{array}$ & $\begin{array}{c}22.591 \\
(14.180)\end{array}$ & $0.095^{*}$ \\
\hline $\begin{array}{l}\text { Percentage donated of the } 35.000 \\
\text { IDR }\end{array}$ & 44.62 & 64.55 & \\
\hline $\mathrm{N}$ & 349 & 408 & 757 \\
\hline \multicolumn{4}{|c|}{$\begin{array}{l}\text { Standard deviations in parentheses; } \\
\text { Figure A3.2 in the appendix shows the histogram of the donations made for the full sample. The histograms } \\
\text { for the sub-samples (urban and rural residents) can be found in figures A3.3 and A3.4). } \\
\text { Column (3) shows } p \text {-value for mean difference test that was conducted with linear regression models and } \\
\text { clustered standard errors at village/city level. } \\
{ }^{*} p<0.1,{ }^{* *} p<0.05,{ }^{* * *} p<0.01\end{array}$} \\
\hline
\end{tabular}

Table 3.9: Descriptives for donations

Table 3.10 presents regression results on the binary donation decision and the amount donated. Column (1) tests for correlations between EC and PEB, column (2) presents coefficients and estimated elasticities (lower part of column 2) for the amount donated, and column (3) shows correlates of the binary decision to donate. Results in column (1) reveal that EC is positively correlated with donations to a local environmental organization. General EC and concern about the lack of local action are significantly related to the amount donated, whereas the coefficient of concern about the negative environmental effects of oil palm is just above the critical p-value of 0.1 .

Results from the full model specifications in columns (2) and (3) show that place of residence is significantly associated with donation behavior. Rural residents donate 62 percent more and overall have a 19 percentage point higher likelihood to donate than urban residents. Regarding social proximity to agriculture, we find that respondents who feel more connected with oil palms engage less in donations to Harapan Rainforest. A one-point increase on the OIS oil palm scale decreases the

\footnotetext{
20 The amount in USD shown was converted with the conversion rate from June 2019.
} 
Chapter 3: Environmental concern and pro-environmental behavior among residents in an oil palm cultivating hotspot

amount donated by 31 percent on average and the overall probability to donate by two percentage points. Regarding nature connectedness, respondents who have a preference for more diverse landscapes donate 31 percent more and have a six-percentage point higher probability to make a donation compared to respondents who prefer more homogenous landscapes. We also find a positive correlation between self-reported participation in PEB and the amount donated, our observed measure of PEB.

Column (2) shows that when adding further covariates to the model on the amount donated, the EC measures turn insignificant. Since similar factors are correlated with EC (see tables 3.6 and 3.7) and PEB (table 3.10, column 2), it is likely that EC acts as a mediator, implying e.g. that rural households have higher EC and accordingly a higher willingness to donate.

As a robustness check, we estimated a double-hurdle model on the decision to donate (first hurdle) and the amount donated (second hurdle). Results are very similar to the results presented in table 3.10 and can be found in the appendix (tables A3.1 and A3.2).

\begin{tabular}{|c|c|c|c|}
\hline & $\begin{array}{l}\text { Amount } \\
\text { donated }\end{array}$ & Amount donated $^{1}$ & $\begin{array}{c}\text { Donation } \\
\text { decision }\end{array}$ \\
\hline & (1) & (2) & (3) \\
\hline \multicolumn{4}{|l|}{ Sociodemographics } \\
\hline Gender of household head ( $1=$ female) & & $\begin{array}{l}-0.13 \\
(0.21) \\
\end{array}$ & $\begin{array}{l}-0.02 \\
(0.05) \\
\end{array}$ \\
\hline Age of household head & & $\begin{array}{l}-0.003 \\
(0.005) \\
\end{array}$ & $\begin{array}{c}-0.00007 \\
(0.001) \\
\end{array}$ \\
\hline $\begin{array}{l}\text { Education of household head } \\
\text { (measured in years) }\end{array}$ & & $\begin{array}{l}0.03^{*} \\
(0.02)\end{array}$ & $\begin{array}{l}0.006^{*} \\
(0.004)\end{array}$ \\
\hline Asset index & & $\begin{array}{c}0.35^{* * *} \\
(0.07)\end{array}$ & $\begin{array}{l}0.05^{* *} \\
(0.02)\end{array}$ \\
\hline Number of household members & & $\begin{array}{c}0.01 \\
(0.04) \\
\end{array}$ & $\begin{array}{c}0.01 \\
(0.009) \\
\end{array}$ \\
\hline \multicolumn{4}{|l|}{ Place of residence } \\
\hline Place of residence (1=village) & & $\begin{array}{c}0.97^{* * *} \\
(0.21)\end{array}$ & $\begin{array}{c}0.19 * * * \\
(0.05)\end{array}$ \\
\hline $\begin{array}{l}\text { Household migrated to current place } \\
\text { of living ( } 1=y e s)\end{array}$ & & $\begin{array}{c}0.14 \\
(0.12) \\
\end{array}$ & $\begin{array}{c}0.01 \\
(0.03)\end{array}$ \\
\hline \multicolumn{4}{|l|}{ Social proximity to agriculture } \\
\hline $\begin{array}{l}\text { Socialization (years lived in village } \\
\text { between } 0 \text { and } 18 \text { ) }\end{array}$ & & $\begin{array}{l}-0.02 \\
(0.01)\end{array}$ & $\begin{array}{c}-0.004^{* *} \\
(0.002) \\
\end{array}$ \\
\hline OIS oil palm & & $\begin{array}{c}-0.08^{* *} \\
(0.04)\end{array}$ & $\begin{array}{l}-0.02^{* *} \\
(0.009)\end{array}$ \\
\hline \multicolumn{4}{|l|}{ Nature connectedness } \\
\hline OIS nature & & $\begin{array}{c}0.03 \\
(0.05)\end{array}$ & $\begin{array}{c}0.04^{* * *} \\
(0.01)\end{array}$ \\
\hline $\begin{array}{l}\text { Preference for diverse landscapes } \\
\text { (1=agroforest or rainforest) }\end{array}$ & & $\begin{array}{l}0.37^{* *} \\
(0.17)\end{array}$ & $\begin{array}{l}0.06^{*} \\
(0.03)\end{array}$ \\
\hline
\end{tabular}


Chapter 3: Environmental concern and pro-environmental behavior among residents in an oil palm cultivating hotspot

\begin{tabular}{|c|c|c|c|}
\hline $\begin{array}{l}\text { Hours participated in environmental } \\
\text { activities in the last } 12 \text { months (sum) }\end{array}$ & & $\begin{array}{l}0.002^{*} \\
(0.001)\end{array}$ & $\begin{array}{c}0.0002 \\
(0.0004)\end{array}$ \\
\hline \multicolumn{4}{|l|}{ Environmental concern } \\
\hline General EC (12-item NEP scale) & $\begin{array}{c}1.32 * \\
(0.72) \\
\text { (p-value: } 0.067) \\
\end{array}$ & $\begin{array}{l}-0.03 \\
(0.07)\end{array}$ & $\begin{array}{l}-0.004 \\
(0.02)\end{array}$ \\
\hline $\begin{array}{l}\text { Concern about the negative } \\
\text { environmental effects of oil palm } \\
\text { cultivation }\end{array}$ & $\begin{array}{c}1.18 \\
(0.72) \\
\text { (p-value: } 0.102)\end{array}$ & $\begin{array}{l}0.05 \\
(0.07)\end{array}$ & $\begin{array}{c}0.01 \\
(0.02)\end{array}$ \\
\hline $\begin{array}{l}\text { Concern about the lack of local action } \\
\text { to reduce the negative environmental } \\
\text { effects of oil palm cultivation }\end{array}$ & $\begin{array}{c}2.08 * * * \\
(0.78) \\
\text { (p-value: } 0.007)\end{array}$ & $\begin{array}{l}-0.07 \\
(0.09)\end{array}$ & $\begin{array}{l}-0.01 \\
(0.02)\end{array}$ \\
\hline Constant & $\begin{array}{c}19.38^{* * *} \\
(0.52)\end{array}$ & $\begin{array}{c}2.15^{* * *} \\
(0.53)\end{array}$ & - \\
\hline $\mathrm{N}$ & 757 & 757 & 757 \\
\hline Controls & yes & yes & yes \\
\hline \multicolumn{4}{|c|}{ Elasticities for significant variables (semi-elasticities for dummy variables) } \\
\hline $\begin{array}{l}\text { Education of household head } \\
\text { (measured in years) }\end{array}$ & & $\begin{array}{c}0.29 \\
(0.16)\end{array}$ & \\
\hline Asset index & & $\begin{array}{l}-2.55 \mathrm{e}-09 \\
(5.51 \mathrm{e}-10)\end{array}$ & \\
\hline Place of residence (1=village) & & 0.62 & \\
\hline OIS oil palm & & $\begin{array}{l}-0.31 \\
(0.16)\end{array}$ & \\
\hline $\begin{array}{l}\text { Preference for diverse landscapes } \\
\text { (1=agroforest or rainforest) }\end{array}$ & & 0.31 & \\
\hline $\begin{array}{l}\text { Hours participated in environmental } \\
\text { activities in the last } 12 \text { months (sum) }\end{array}$ & & $\begin{array}{c}0.04 \\
(0.02)\end{array}$ & \\
\hline \multicolumn{4}{|c|}{ 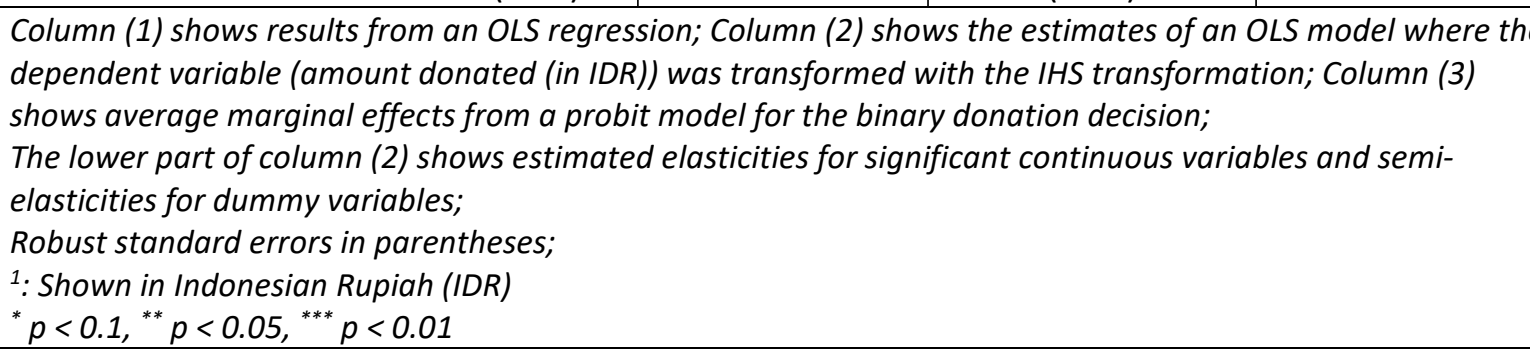 } \\
\hline
\end{tabular}

Table 3.10: Regression results for donation behavior

\subsection{Discussion and conclusion}

We measured EC and PEB of residents living in one of the major oil palm producing regions in the world and compared EC and PEB of rural and urban residents. For this, we measured EC based on a 12-item NEP scale and an oil-palm-related adaptation of the scale. PEB was measured as donations made to a local environmental organization using a donation game. Our results show that rural residents directly involved with oil palm cultivation are significantly more concerned about the environment than urban 
respondents. This is true for general EC, as well as for oil palm-related EC. Furthermore, we find that nature connectedness and preferences for more diverse landscapes are positive correlates of EC, whereas social proximity to agriculture is negatively correlated with EC. Regarding PEB, our results reveal that more than three-quarters of our respondents decided to donate. We further find that rural respondents donate more, that nature connectedness influences donation behavior positively, and proximity to agriculture influences it negatively.

Earlier studies, especially in industrialized countries, have found mixed results concerning differences in EC between rural and urban residents (Huddart-Kennedy et al. 2009; Yu 2014; Mobley 2016). Our study finds that rural residents engaged in oil palm farming are more environmentally concerned. This finding is in line with the study by Sharp and Adua (2009) and Berenguer et al. (2005) and shows that oil palm farmers seem to be aware of the environmental effects of oil palm cultivation. It is interesting to see that even though urban residents are affected by exhaust fumes and waste amongst others in a more intense way than rural residents, besides the negative environmental effects of oil palm cultivation such as water and air pollution, they do have a lower general concern. One reason for the difference in EC between urban and rural residents might be that those respondents that are less concerned about the environment and are directly involved in oil palm cultivation might feel that the economic benefits they receive from the cultivation outweigh the negative environmental effects from oil palms. Another reason might be that the respondents with a lower EC who are not directly involved in oil palm cultivation (the majority of urban residents) might not necessarily connect oil palm cultivation with negative environmental effects but more with economic benefits. Anecdotal evidence from our survey suggests that many urban respondents had the opinion that oil palm cultivation has brought economic welfare to the rural areas.

When looking at PEB, we find that rural respondents donate more money than urban residents which is in line with the findings of Huddart-Kennedy et al. (2009) for self-reported PEB but not with the findings by Yao (2015) for an industrialized nation context and Chileshe and Sampa Moonga (2019) (developing nation context). One reason for the rural-urban behavior difference in our study might be that urban residents do not see the reason to donate to an environmental organization when they are not directly involved in the cultivation of oil palms and hence do not feel responsible for the environmental consequences. In other words, rural respondents that are all oil palm farmers in our case and are responsible for some of the negative environmental effects from oil palm cultivation might feel the necessity to donate to an environmental cause. A second reason might be that urban residents do not connect oil palms with the negative effects such as deforestation and loss of biodiversity and hence, might not see the necessity to donate for such a cause. 
Beyond this, we learn that EC, general as well as oil palm-related EC, and the donations made are positively correlated and are influenced by similar factors as seen in our results. This means that EC might act as a mediator and might explain why rural households that have a higher EC also have a higher willingness to donate. This shows that EC and PEB are indeed positively correlated as shown by Pisano and Lubell (2017) and that this correlation is highly relevant in developing nations, too. In addition, we find that self-reported PEB is higher among urban residents and that self-reported PEB and donations are positively correlated when controlling for geographical residence. Hence, this offers a starting point to strengthen PEB specifically related to oil palm cultivation and the negative environmental effects, especially, in urban areas.

Our study offers two policy implications to consider. Firstly, many rural residents who are directly involved in oil palm cultivation are aware of the environmental consequences of oil palm cultivation, show concern, and engage in PEB. While awareness and concern do not necessarily translate directly into PEB, this nonetheless offers a starting point for discussions and planning of interventions to foster sustainable oil palm cultivation. Secondly, when considering all local stakeholders, urban respondents who are mostly not directly involved in the oil palm sector are less concerned. They also donate less than their rural counterparts; however, for self-reported PEB they tend to engage more. Accordingly, urban residents may fail to connect the agrarian transformation with negative environmental effects. A similar failure of the general public to connect agriculture and the environment has been observed in other studies (Sharp and Adua 2009). To overcome this lack of connectedness and strengthen EC and $\mathrm{PEB}$, especially in the urban context, providing environmental education and information may be a promising approach. The provision of environmental education and information seems particularly relevant since our study finds - similar to studies in industrialized countries - that EC and PEB are positively correlated. 


\section{Appendix}

\begin{tabular}{|c|c|c|c|}
\hline & $\begin{array}{c}\text { Unconditional } \\
\text { expected value } \\
E(Y \mid X) \\
\end{array}$ & $\begin{array}{l}\text { Donation decision } \\
\qquad \operatorname{Pr}(Y>0 \mid X)\end{array}$ & $\begin{array}{c}\text { Conditional expected } \\
\text { value } \\
E(Y \mid X, Y>0) \\
\end{array}$ \\
\hline & (1) & (2) & (3) \\
\hline \multicolumn{4}{|l|}{ Sociodemographics } \\
\hline $\begin{array}{l}\text { Gender of household head } \\
\text { (1=female) }\end{array}$ & $\begin{array}{l}-1.534 \\
(2.386) \\
\end{array}$ & $\begin{array}{l}-0.02 \\
(0.05) \\
\end{array}$ & $\begin{array}{l}-1.090 \\
(2.061) \\
\end{array}$ \\
\hline Age of household head & $\begin{array}{l}-0.051 \\
(0.060)\end{array}$ & $\begin{array}{c}-0.00007 \\
(0.001)\end{array}$ & $\begin{array}{l}-0.050 \\
(0.050)\end{array}$ \\
\hline $\begin{array}{l}\text { Education of household head } \\
\text { (measured in years) }\end{array}$ & $\begin{array}{l}0.304^{*} \\
(0.182)\end{array}$ & $\begin{array}{l}0.006^{*} \\
(0.004)\end{array}$ & $\begin{array}{l}0.156 \\
(0.156)\end{array}$ \\
\hline Asset index & $\begin{array}{c}5.347 * * * \\
(0.890)\end{array}$ & $\begin{array}{l}0.05^{* *} \\
(0.02)\end{array}$ & $\begin{array}{c}4.185^{* * *} \\
(0.823)\end{array}$ \\
\hline Number household members & $\begin{array}{l}-0.511 \\
(0.488)\end{array}$ & $\begin{array}{c}0.01 \\
(0.009)\end{array}$ & $\begin{array}{l}-0.781 * \\
(0.402)\end{array}$ \\
\hline \multicolumn{4}{|l|}{ Place of residence } \\
\hline Place of residence (1=village) & $\begin{array}{c}9.040^{* * *} \\
(2.239) \\
\end{array}$ & $\begin{array}{c}0.19 * * * \\
(0.05) \\
\end{array}$ & $\begin{array}{l}4.668^{* *} \\
(2.051) \\
\end{array}$ \\
\hline $\begin{array}{l}\text { Household migrated to current } \\
\text { place of living (1=yes) }\end{array}$ & $\begin{array}{l}2.810^{* *} \\
(1.407) \\
\end{array}$ & $\begin{array}{c}0.01 \\
(0.03) \\
\end{array}$ & $\begin{array}{l}2.531^{* *} \\
(1.221)\end{array}$ \\
\hline \multicolumn{4}{|l|}{ Social proximity to agriculture } \\
\hline $\begin{array}{l}\text { Socialization (years lived in } \\
\text { village between } 0 \text { and } 18 \text { ) }\end{array}$ & $\begin{array}{l}-0.033 \\
(0.112)\end{array}$ & $\begin{array}{c}-0.004 * * \\
(0.002)\end{array}$ & $\begin{array}{c}0.069 \\
(0.094)\end{array}$ \\
\hline OIS oil palm & $\begin{array}{l}-0.482 \\
(0.454)\end{array}$ & $\begin{array}{l}-0.02 * * \\
(0.009) \\
\end{array}$ & $\begin{array}{c}0.025 \\
(0.388) \\
\end{array}$ \\
\hline \multicolumn{4}{|l|}{ Connectedness with nature } \\
\hline OIS nature & $\begin{array}{c}-1.716^{* * *} \\
(0.448)\end{array}$ & $\begin{array}{c}0.04 * * * \\
(0.01)\end{array}$ & $\begin{array}{c}-2.571 * * * \\
(0.447)\end{array}$ \\
\hline $\begin{array}{l}\text { Preference for diverse } \\
\text { landscapes ( } 1 \text { =agroforest or } \\
\text { rainforest) }\end{array}$ & $\begin{array}{c}4.729 * * \\
(1.845)\end{array}$ & $\begin{array}{l}0.06 * \\
(0.03)\end{array}$ & $\begin{array}{l}3.430^{* *} \\
(1.596)\end{array}$ \\
\hline \multicolumn{4}{|l|}{ Other environmental behavior } \\
\hline $\begin{array}{l}\text { Hours participated in } \\
\text { environmental activities in the } \\
\text { last } 12 \text { months (sum) }\end{array}$ & $\begin{array}{c}0.041^{* * *} \\
(0.014)\end{array}$ & $\begin{array}{c}0.0002 \\
(0.0004)\end{array}$ & $\begin{array}{c}0.037 * * * \\
(0.013)\end{array}$ \\
\hline \multicolumn{4}{|l|}{ Environmental concern } \\
\hline General EC (12-item NEP scale) & $\begin{array}{l}-0.317 \\
(0.849) \\
\end{array}$ & $\begin{array}{l}-0.004 \\
(0.02) \\
\end{array}$ & $\begin{array}{l}-0.230 \\
(0.758) \\
\end{array}$ \\
\hline $\begin{array}{l}\text { Concern about the negative } \\
\text { environmental effects of oil } \\
\text { palm cultivation }\end{array}$ & $\begin{array}{c}0.626 \\
(0.848)\end{array}$ & $\begin{array}{c}0.01 \\
(0.02)\end{array}$ & $\begin{array}{c}0.307 \\
(0.752)\end{array}$ \\
\hline $\begin{array}{l}\text { Concern about the lack of local } \\
\text { action to reduce the negative } \\
\text { environmental effects of oil } \\
\text { palm cultivation }\end{array}$ & $\begin{array}{c}-0.708 \\
(1.098)\end{array}$ & $\begin{array}{c}-0.01 \\
(0.02)\end{array}$ & $\begin{array}{l}-0.470 \\
(0.959)\end{array}$ \\
\hline$N$ & 757 & 757 & 623 \\
\hline Control variables included & yes & yes & yes \\
\hline
\end{tabular}


IDR. Column (2) shows average marginal effects from a probit model for the binary decision of whether to donate or not; column (3) reports average marginal effects for the intensity decision conditional on the decision to donate in 'OOO IDR. An OLS with log transformation was used for the estimation of the results in columns (1) and (3).

Standard errors in parentheses;

${ }^{*} p<0.1,{ }^{* *} p<0.05,{ }^{* * *} p<0.01$

For the two-step model, we selected a probit model (Humphreys 2013) for modeling the binary donation decision. For the second part of the model, the intensity decision, we had to select between a generalized linear model (GLM) and an ordinary least squares (OLS) approach. In cases where one finds evidence of heteroscedasticity in the OLS residuals on the log-scale, OLS will be biased (Manning and Mullahy 2001) and GLM is preferred. Additionally, if the OLS log-scale residuals are heavier tailed than normal we would prefer OLS with log transformation over GLM to reduce precision losses (Manning and Mullahy 2001). Our data shows that we prefer the OLS model over the GLM estimation as we firstly, do not find proof for heteroscedasticity present $(p=0.2334)$ which was tested with a White test. Secondly, the kurtosis value for the amount donated (log-scale residuals) shows a value of 2.40. Hence, we use an OLS with log transformation. As we applied a log-transformed OLS regression we have to do a retransformation to go from log(y_hat) to y_hat. For this retransformation, we apply Duan's smearing estimator (Duan 1983). In addition, we have to apply a non-parametric bootstrapping to compute the correct standard errors and confidence intervals for the unconditional marginal effects (Belotti et al. 2015).

Table A3.1: Estimates for donations made using a two-step model 
Chapter 3: Environmental concern and pro-environmental behavior among residents in an oil palm cultivating hotspot

\begin{tabular}{|c|c|c|}
\hline & $\begin{array}{c}\text { (1) } \\
\text { Amount donated (log) }\end{array}$ & $\begin{array}{c}\text { (2) } \\
\text { Selection equation }\end{array}$ \\
\hline Age of household head & $\begin{array}{l}-0.002 \\
(0.002)\end{array}$ & $\begin{array}{l}-0.0001 \\
(0.005)\end{array}$ \\
\hline $\begin{array}{l}\text { Education of household head } \\
\text { (measured in years) }\end{array}$ & $\begin{array}{c}0.007 \\
(0.008)\end{array}$ & $\begin{array}{l}0.03^{*} \\
(0.02)\end{array}$ \\
\hline $\begin{array}{l}\text { Gender of household head } \\
\text { (1=female) }\end{array}$ & $\begin{array}{l}-0.07 \\
(0.10)\end{array}$ & $\begin{array}{l}-0.09 \\
(0.19)\end{array}$ \\
\hline Asset index & $\begin{array}{c}0.21 * * * \\
(0.04)\end{array}$ & $\begin{array}{l}0.22 * * \\
(0.09)\end{array}$ \\
\hline Number household members & $\begin{array}{c}-0.04^{* *} \\
(0.02) \\
\end{array}$ & $\begin{array}{c}0.04 \\
(0.04) \\
\end{array}$ \\
\hline Place of residence (1=village) & $\begin{array}{l}0.22^{* *} \\
(0.09) \\
\end{array}$ & $\begin{array}{c}0.78^{* * *} \\
(0.18)\end{array}$ \\
\hline $\begin{array}{l}\text { Socialization (years lived in } \\
\text { village between } 0 \text { and 18) }\end{array}$ & $\begin{array}{c}0.006 \\
(0.005) \\
\end{array}$ & $\begin{array}{l}-0.02^{*} \\
(0.009) \\
\end{array}$ \\
\hline $\begin{array}{l}\text { Hours participated in } \\
\text { environmental activities (sum) }\end{array}$ & $\begin{array}{l}0.002^{* * *} \\
(0.0006)\end{array}$ & $\begin{array}{l}0.0006 \\
(0.002)\end{array}$ \\
\hline OIS nature & $\begin{array}{c}-0.13^{* * *} \\
(0.02) \\
\end{array}$ & $\begin{array}{c}0.16 * * * \\
(0.04)\end{array}$ \\
\hline $\begin{array}{l}\text { Preference for diverse } \\
\text { landscapes (1=agroforest or } \\
\text { rainforest) }\end{array}$ & $\begin{array}{l}0.18^{* *} \\
(0.08)\end{array}$ & $\begin{array}{l}0.26^{*} \\
(0.14)\end{array}$ \\
\hline Constant & $\begin{array}{c}3.45^{* * *} \\
(0.30)\end{array}$ & $\begin{array}{l}-0.39 \\
(0.49) \\
\end{array}$ \\
\hline OIS oil palm & & $\begin{array}{c}-0.10^{* *} \\
(0.04)\end{array}$ \\
\hline $\mathrm{N}$ & 757 & 623 \\
\hline \multicolumn{3}{|c|}{$\begin{array}{l}\text { Estimated coefficients from a Heckman selection model. } \\
\text { Standard errors presented in parentheses. } \\
\text { Wald test of independent equations (rho }=0 \text { ): chi2(1) =0.02 (p-value =0.875) } \\
\text { We follow Wooldridge (2010) and use the logarithmic transformation of our outcome variable the amount } \\
\text { donated to make sure that only positive values are predicted. } \\
\text { We assume that the connectedness with oil palms affects the decision to donate negatively as those } \\
\text { respondents that feel connected to oil palms probably would rather not support tree planting to tackle the } \\
\text { negative environmental effects of oil palm cultivation. We further assume that the connectedness with oil } \\
\text { palms does not play a role in the amount donated which is supported by the insignificance of this coefficient } \\
\text { for the intensity decision as can be seen in table A1. } \\
\text { The Wald test of independence shows that we cannot reject the independence assumption (p-value }=0.875 \text { ). } \\
\text { Furthermore, the inverse Mills ratio is significant in the model and the variance inflation factors (VIFs) of the } \\
\text { regression of the inverse Mills ratio on the remaining parameters in our model are } 13.49 \text { (without OIS oil } \\
\text { palm) and } 13.65 \text { (with OIS oil palm). Hence, we prefer the two-step model for our estimations. The critical } \\
\text { level for conducting this test is } 30 \text { (Madden 2008). } \\
* p<0.1, * * p<0.05, * * * p 0.01 \text {. }\end{array}$} \\
\hline
\end{tabular}

Table A3.2: Heckman selection model results 

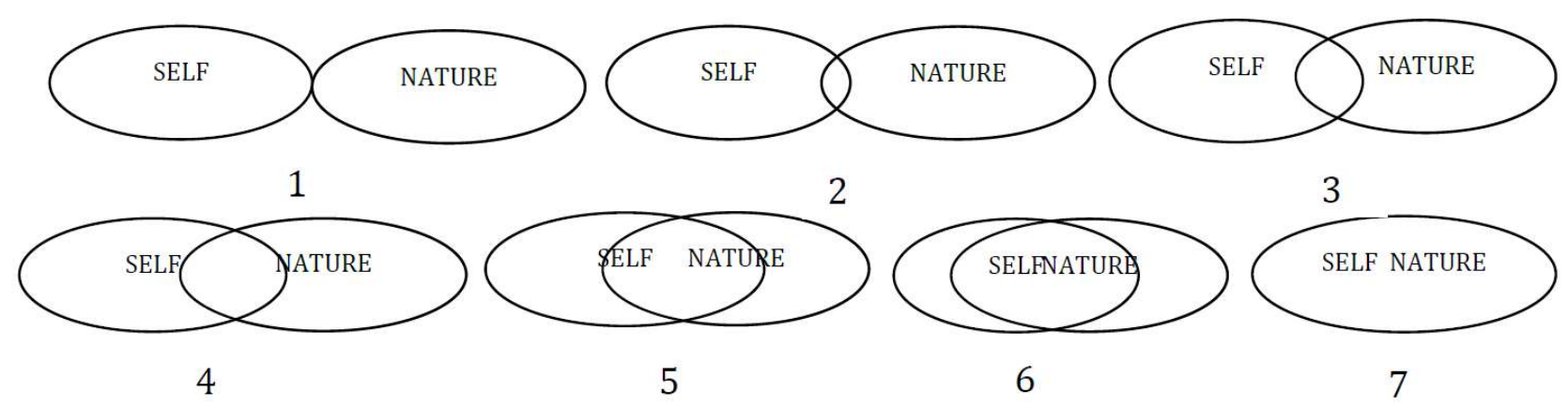

Figure A3.1: OIS scale (Aron et al. 1992)

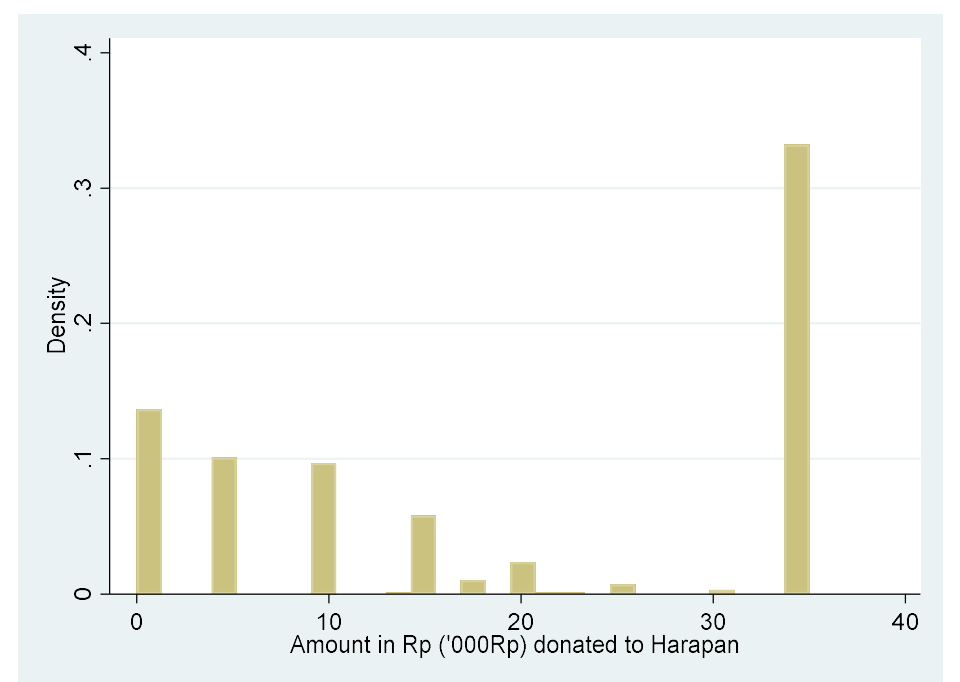

Figure A3.2: Histogram for donations (in IDR)

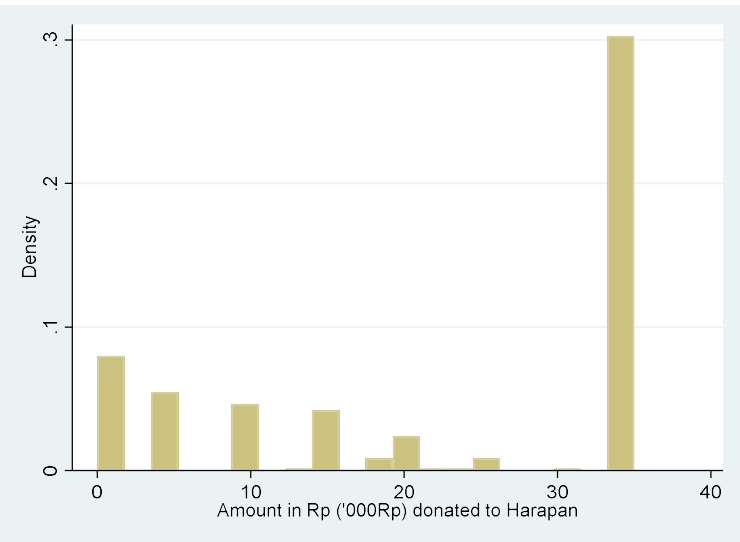

Figure A3.3: Donations for respondents currently in the village (in IDR)

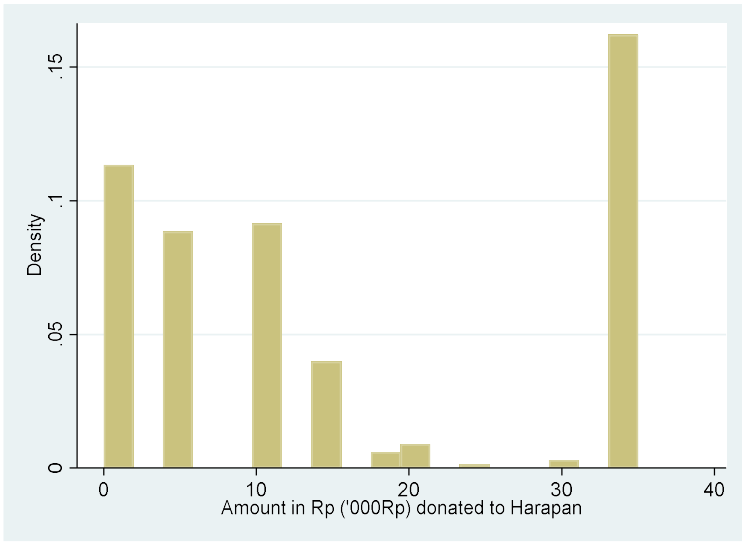

Figure A3.4: Donations for respondents currently living in the city (in IDR) 


\title{
4 Climate change perceptions among small-scale oil palm farmers in Indonesia ${ }^{21}$
}

\begin{abstract}
Climate-related disasters such as floods, droughts, and storms have increased, and rising temperatures are leading to an increase in crop diseases, which might negatively affect agricultural yields and hence, the livelihoods of farmers. Agriculture, on the other hand, enhances climate change by releasing $\mathrm{CO}_{2}$ into the atmosphere. Various research exists that looks at climate change perceptions of individuals, yet evidence remains limited with regards to climate change perceptions of small-scale oil palm farmers living in a setting of rapid land use transformation. This paper explores the question of what factors are associated with oil palm farmers' climate change perceptions in Indonesia. Our results reveal that almost 75 percent of all respondents are aware of climate change and about 60 percent feel personally affected by it. Results from multinomial logit estimations reveal that age, education, and wealth are important determinants that are associated with climate change awareness and perceived affectedness. Finally, we cannot find strong associations between the experience of extreme weather events and climate change perceptions among the farmers.
\end{abstract}

Keywords: Climate change, climate change awareness, perceived affectedness, oil palm farmers, Indonesia

\footnotetext{
${ }^{21}$ This chapter is work in progress and co-authored by Meike Wollni (MW). Karina Brenneis (KB) conceptualized the research idea, collected, analyzed, interpreted the data, and wrote the manuscript. MW commented at different stages of the research and helped with the revision of the manuscript.

Funding: This study was funded by the Deutsche Forschungsgemeinschaft (DFG, German Research Foundation) - grant number 192626868 - in the framework of the collaborative German-Indonesian research project CRC 990.
} 


\subsection{Introduction}

Due to a growing population and the increasing demand for agricultural products, pressure on agricultural land has augmented worldwide (Lasco et al. 2011; Arora 2019). Thereby agriculture has added to the release of massive amounts of $\mathrm{CO}_{2}$ contributing to climate change and in return, agriculture itself is negatively affected by it (Arora 2019). According to the newest report of the World Meteorological Organization (WMO) of 2020, climate-related disasters (floods, droughts, and storms) have increased, and rising temperatures are leading to the loss of species and ecosystems, and an increase in crop diseases which can reduce agricultural yields and thus, negatively affect livelihoods (Arora 2019; Peace 2020; WMO 2020).

In this context, the expansion of oil palm cultivation in Indonesia is a very prominent example of the interdependence of agriculture and the climate. An intense land transformation has been taking place due to a rising demand for vegetable oil, biofuel, cosmetics, and industrial and agrochemical products (McCarthy 2010). In Indonesia, which has been the world's biggest producer and exporter of palm oil since 2008 (Rist et al. 2010; Gatto et al. 2015) an area of about 14.5 million hectares is being cultivated with oil palms (FAOStat 2021). In addition to companies that invest in oil palm cultivation and drive the expansion, about 40 percent of the oil palm land is managed by small-scale farmers today (Euler et al. 2016b). Besides the overall positive economic effects generated, the expansion of oil palm monocultures has led to tremendous negative environmental effects, e.g. through the loss of forest areas, decrease in biodiversity, and air and water quality (Feintrenie et al. 2010b; Gibson et al. 2011; Merten et al. 2016; Austin et al. 2017; Dislich et al. 2017). The massive loss of forest areas to clear land for the expansion of oil palm plantations contributes to climate change (Paterson and Lima 2017) by releasing large amounts of $\mathrm{CO}_{2}$ into the atmosphere (Campbell et al. 2017). Indonesia has the highest rate of forest loss and the fourth-highest rate of greenhouse gas emissions worldwide (Margono et al. 2014; Austin et al. 2015), reflecting the continuing threat of climate change on agriculture and vice versa and the need to find suitable adaptation strategies.

Many studies analyze and identify relevant determinants associated with climate change perceptions among individuals. Yet, evidence remains limited for climate change perceptions among small-scale oil palm farmers living in a setting of rapid land use transformation. This study addresses one main research objective. It aims to understand the determinants that are associated with the perceptions of climate change awareness and perceived affectedness among small-scale oil palm farmers in Indonesia.

The implications that climate change has on agriculture are already visible. In a study by Paterson et al. (2015), future projections for the suitability of oil palms in Malaysia and Indonesia indicate that oil 
palm yields will decrease: The increasing frequency of droughts in South East Asia has already led to a decline in oil palm yields (Paterson et al. 2015). Besides, model projections show that rising temperatures by $2{ }^{\circ} \mathrm{C}$ above the optimum for oil palm cultivation in combination with a decrease in rainfall by 10 percent will result in a yield decrease by around 30 percent (Paterson et al. 2015). In another study by Paterson et al. (2013), it was shown that due to a changing climate with increasing temperatures the oil palms will be exposed to greater stress and suffering from more diseases. This is in line with the results from the study by Rival (2017). As Stern (2007) and Paterson et al. (2013) explain, much of the global warming experienced today and for the next 30 years is based on emissions that have already been released into the atmosphere. Yet, the degree of future global warming highly depends on emissions of today and the near future (Stern 2007; Paterson et al. 2013). Hence, adaptation strategies have to become a central strategy today to slow down and decrease the implications of climate change in the long term.

The rest of the paper is organized as follows: Section 2 presents the conceptual framework, study context, data, and statistical framework. The results are presented in section 3. Section 4 discusses the results and concludes.

\subsection{Study context and data}

\subsubsection{Conceptual framework}

It is relevant to develop a good understanding of farmers' perceptions of climate change because farmers that feel negatively affected by climate change and hence, perceive a problem with this affectedness might be more likely to adapt to it compared to farmers that do not feel affected by it (Simelton et al. 2013). Hence, a better understanding of climate change perceptions allows policymakers to support small-scale oil palm farmers by developing suitable climate change adaptation measures.

Plenty of studies focus on climate change perceptions, showing that overall, individuals tend to be aware of climate change and its effects (Bohensky et al. 2013; Dhanya and Ramachandran 2015; Mulenga et al. 2017; Ullah et al. 2019) with variations between countries (Lee et al. 2015). Studies show that climate change awareness and perceived affectedness vary with the respective sociodemographics. With regards to farmers, the studies by Muttarak and Lutz (2014) and Lee et al. (2015), for example, show that education plays an important role in the level of awareness, perceived affectedness, and reacting to climate change. According to Muttarak and Lutz (2014), direct effects include the accumulation of knowledge and skills with which the interviewed farmers can increase 
their adaptive capacity. For example, weather forecasts can be better processed and classified through abstract thinking that is obtained with formal education (Mileti and Sorensen 1990). Besides, it could be shown that more educated individuals have higher risk awareness compared to less-educated individuals (Muttarak and Lutz 2014). Indirect effects of education on vulnerability reduction include better access to useful information and a higher social capital and larger social networks (Cotten and Gupta 2004; Wen et al. 2011; Muttarak and Lutz 2014). Yet, while education seems to be positively associated with climate change awareness it does not necessarily lead to feel affected by it (Poortinga et al. 2019). Hence, in our setting, we would expect that the more educated farmers are more aware of climate change compared to less educated farmers. Following the study by Poortinga et al. (2019), we do not expect that the more aware farmers necessarily perceive being more strongly affected by climate change.

Simelton et al. (2013) measures perceptions of rainfall among farmers in Botswana and Malawi and find that wealth which includes assets and access and use of agricultural land, and off-farm income sources amongst others, play a role in different perceived rainfall changes. Singh et al. (2017) also identify wealth as one important factor for variations in climate change perceptions and adaptation measures among Indian farmers. Reasons for the importance of wealth are the capability of farmers to intensify their production systems and invest in improved varieties compared to the poorer farmers (Singh et al. 2017). The richer farmers also have potentially more access to agricultural advice and training (Singh et al. 2017). Hence, we would expect that overall the wealthier oil palm farmers in our study region are the ones to be more aware of climate change and do also have a higher perceived affectedness by climate change compared to the poorer farmers.

Finally, age has been identified by several studies as another important factor associated with climate change perceptions (Simelton et a. 2013; Lee et al. 2015; Poortinga et al. 2019). It has been shown that older people are more involved in their social networks and have more to lose from changes that would be needed to mitigate climate change than younger people (Poortinga et al. 2019). In addition, worldviews that influence climate change perceptions still form in younger aged individuals compared to older individuals which might lead to a higher climate change awareness among younger people (Stevenson et al. 2014). Scholars have also shown that older people tend to become more (politically) conservative, which in itself is an important factor in how climate change is perceived (Cornelis et al. 2009). According to these studies, we expect that the younger oil palm farmers to be more aware of climate change than the older farmers. 


\subsubsection{Study area and sampling}

We conducted our research in the lowland regions of Jambi Province, Sumatra, Indonesia (figure 4.1). The island of Sumatra is a hotspot for biodiversity with an increasing area under monoculture crops like rubber and oil palm. Most of the oil palm plantations in Jambi have been established on former forest land (Koh and Wilcove 2008; Schwarze et al. 2015) as well as on land that was used for rubber and food crops (Schwarze et al. 2015). About 75 percent of the land in Jambi Province on Sumatra used for oil palm cultivation is managed by small-scale farmers (BPS-Statistics Indonesia 2019).
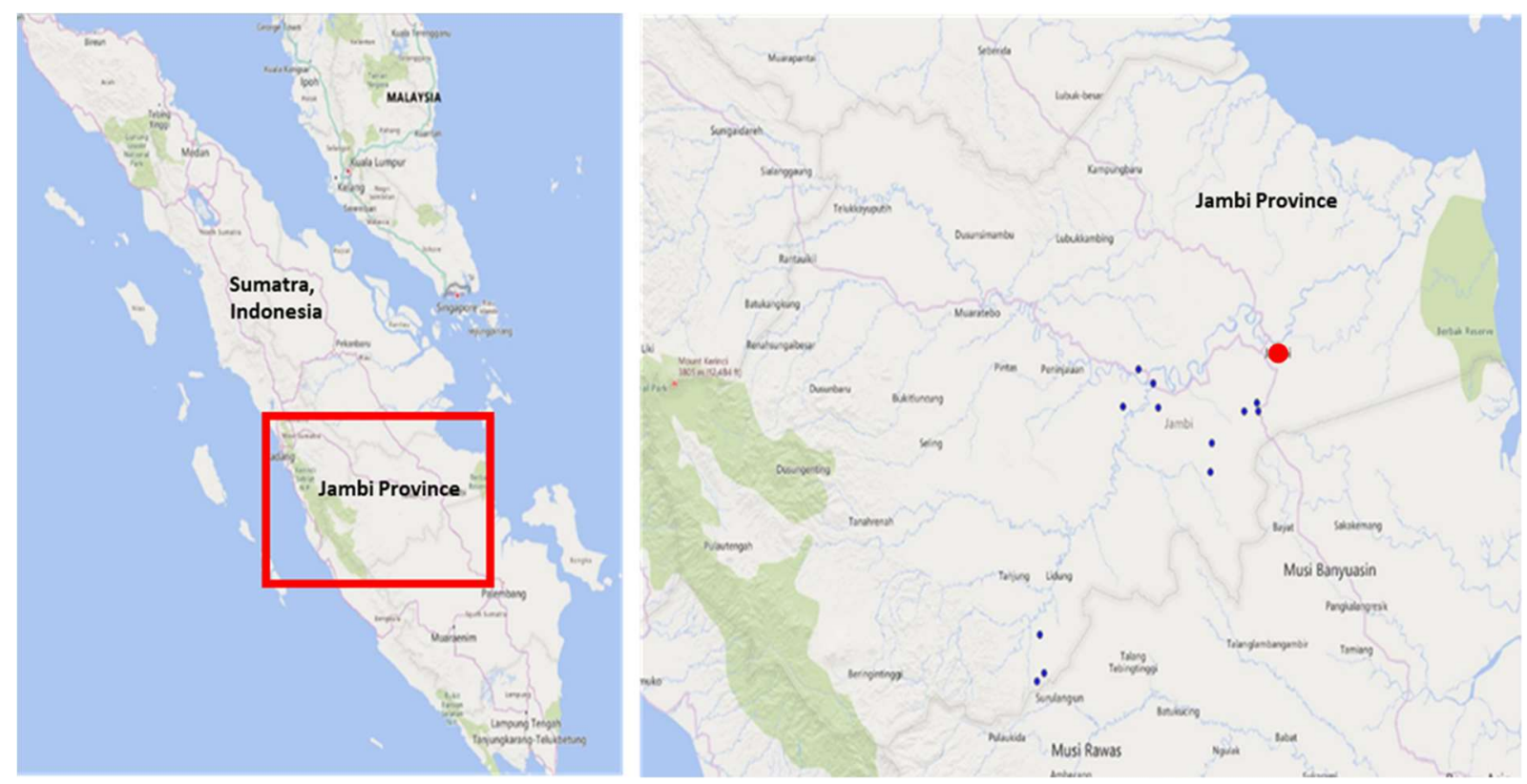

Figure 4.1: Research area: Jambi, Sumatra, Indonesia: On the left photo you can see the map of the island of Sumatra, Indonesia; On the right photo you can see Jambi Province on Sumatra, Indonesia (The blue dots mark the villages where the interviews were conducted and the orange dot marks Jambi City, the capital of Jambi Province.)

We interviewed oil palm farmers in three oil palm growing districts in Jambi Province, namely Muaro Jambi, Batanghari, and Sarolangun where the area under oil palm cultivation has expanded the most between 1995 and 2011 (Euler et al. 2016b). A total of 12 villages were selected. In 10 of these villages, 40 oil palm farmers per village were randomly selected and interviewed. Due to logistical problems in two of these villages where only 20 farmers could be interviewed, two additional villages had to be selected and another 24 oil palm farmers in each of the two villages were chosen randomly to participate. A total of 408 oil palm farmers could be interviewed. We included transmigrant and local villages in our sample to account for this composition of farmers in Jambi Province ${ }^{22}$. The results that

\footnotetext{
22 In the 1980s the Indonesian government supported oil palm cultivation through the transmigration program. This program was set up to support socio-economic development. The families that participated in the transmigration program were from the densely populated island of Java and were relocated to Sumatra and other islands (Rist et al. 2010; Gatto et al. 2015; Krishna et al. 2017). They received two to three hectares of land and support from the government to cultivate cash crops such as oil palms and rubber (Gatto et al. 2015).
} 
we derive and present in this study are context-specific to our sample of oil palm farmers in Jambi Province.

\subsubsection{Estimation strategy}

For the analysis, we are interested in the determinants that are associated with climate change awareness and perceived affectedness by small-scale oil palm farmers. As outcome variables we have three categorical groups where each respondent belongs to one specific group: 1) Not aware of climate change, 2) Do not feel personally affected by climate change, and 3) Feel personally affected by climate change. To understand the determinants that are associated with the respective group affiliations, we apply a multinomial logit model. Following Long and Freese (2006), this model can formally be written as:

$\ln \Omega_{m \mid b}(x)=\ln \frac{\operatorname{Pr}(y=m \mid x)}{\operatorname{Pr}(y=b \mid x)}=x \beta_{m \mid b}$ for $m=1$ to 3

where $\ln \Omega_{m \mid b}$ is the log odds of 1) Not aware of climate change, 2) Do not feel personally affected by climate change and 3) Feel personally affected by climate change, and b is the base category or comparison group out of the three categories that we are looking at in our study. $x$ is a vector of independent variables that are sociodemographics, wealth indicators, and previous experiences with extreme weather events in the last five years. $\beta$ includes parameters to be estimated.

\subsubsection{Descriptive statistics}

Table 4.1 shows the descriptive statistics for the sociodemographics and wealth indicators used as independent variables in our analysis. The descriptives for the sociodemographics and the wealth indicators represent the characteristics of an average oil palm farmer in our study region.

\begin{tabular}{|l|c|l|}
\hline \multicolumn{1}{|c|}{ Variable } & Mean & \\
\hline Sociodemographics & \multicolumn{2}{|c|}{ Description } \\
\hline Age & $\begin{array}{c}50.54 \\
(11.00)\end{array}$ & Age of household head \\
\hline Education & $\begin{array}{c}9.53 \\
(4.28)\end{array}$ & Education in years of household head \\
\hline Number of & $\begin{array}{l}3.79 \\
(1.30)\end{array}$ & Number of members living in the household \\
household members & $\begin{array}{c}0.23 \\
(0.42)\end{array}$ & Dummy variable if the household was part of the \\
\hline Transmigrant & & \\
\hline
\end{tabular}




\begin{tabular}{|l|c|l|}
\hline Crop diversification & $\begin{array}{c}1.52 \\
(0.54)\end{array}$ & $\begin{array}{l}\text { Measures diversification through the following forms/crops of } \\
\text { cultivation: oil palms, rubber, rubber agroforestry, rice }\end{array}$ \\
\hline Wealth indicators \\
\hline Hectares oil palms & $\begin{array}{c}4.37 \\
(4.43)\end{array}$ & Hectares of oil palms cultivated by the household \\
\hline Asset index & $\begin{array}{c}1.83 e-11 \\
(0.62)\end{array}$ & $\begin{array}{l}\text { The asset index was constructed with a factor analysis. The } \\
\text { following assets (dummy variables) are included: air } \\
\text { conditioner, mobile phone, refrigerator, generator, TV, stereo } \\
\text { system, computer, washing machine, fan, car/truck, and radio. }\end{array}$ \\
\hline $\begin{array}{l}\text { Other income } \\
\text { sources besides } \\
\text { agriculture (1/0) }\end{array}$ & $\begin{array}{c}0.58 \\
(0.49)\end{array}$ & $\begin{array}{l}\text { Dummy if the household has other income sources apart from } \\
\text { agriculture (=1) or not (=0) }\end{array}$ \\
\hline N & 408 & \\
\hline \multicolumn{2}{|l|}{ Standard deviations in parentheses }
\end{tabular}

Table 4.1: Descriptives statistics for sociodemographics and wealth indicators

\subsection{Results}

\subsubsection{Experience of extreme weather events}

Table 4.2 presents descriptive statistics for different extreme weather events experienced by the oil palm farmers in our sample in the last five years. Even though we find many farmers, especially, for the experience of floods and crop diseases, who have not experienced these events yet, about 18 percent and 22 percent respectively have at least been slightly affected by floods and crop diseases or even severely. For droughts that have been experienced by farmers, about 53 percent of the oil palm farmers stated to have been affected at least slightly if not severely in the last five years. This information shows that the oil palm farmers in the study region have been affected by extreme weather events that are potentially associated with climate change.

\begin{tabular}{|l|l|}
\hline & \multicolumn{1}{|c|}{ Distribution } \\
\hline Has been affected by droughts in the last & 1 = not at all affected: 192 (47 percent) \\
five years & 2 slightly affected: 133 (33 percent) \\
& 3 = severely affected: 83 (20 percent) \\
\hline Has been affected by floods in the last five & 1 = not at all affected: 336 (82 percent) \\
years & 2 = slightly affected: 48 (12 percent) \\
& 3 = severely affected: 24 (6 percent) \\
\hline Has been affected by crop diseases in the & 1 = not at all affected: 321 (79 percent) \\
last five years & 2 slightly affected: 76 (19 percent) \\
\hline $\mathrm{N}$ & 3 = severely affected: 11 (3 percent) \\
\hline
\end{tabular}

Table 4.2: Previous experiences with extreme weather events 


\subsubsection{Determinants of climate change awareness and perceived affectedness}

While the farmers have experienced such extreme weather events that are possibly associated with climate change, we would like to better understand which determinants are actually associated with climate change awareness and perceived affectedness. Therefore, we first have a look at table 4.3, where the descriptives of the oil palm farmers' climate change perceptions are shown. We can see that 233 farmers feel personally affected by climate change, 65 do not feel personally affected by it and 110 farmers are not aware of climate change.

\begin{tabular}{|l|c|}
\hline & Frequency \\
\hline 1) Not aware of climate change & 110 \\
\hline $\begin{array}{l}\text { 2) Do not feel personally affected by } \\
\text { climate change }\end{array}$ & 65 \\
\hline $\begin{array}{l}\text { 3) Feel personally affected by climate } \\
\text { change }\end{array}$ & 233 \\
\hline N & 408 \\
\hline
\end{tabular}

Table 4.3: Descriptive statistics for climate change awareness and perceived affectedness

To gain an understanding of the determinants that are associated with climate change awareness and perceived affectedness, we have a look at the results from the multinomial logit model in table 4.4. We compare the group affiliation of each oil palm farmer for one of the following three categories presented in table 3: (1) Not aware of climate change, (2) Do not feel personally affected by climate change, and (3) Feel personally affected by climate change. The second category (2) Do not feel personally affected by climate change, has been used as the base category.

When focusing on the sociodemographics in table 4.4 at first, we find that the farmers in the groups (1) Not aware of climate change and (3) Feel personally affected by climate change, are older compared to the farmers who do not feel personally affected by climate change. Comparing groups (2) and (3) with each other, we can see that farmers in the group (3) Feel personally affected by climate change tend to be younger compared to the farmers in the group (2) Do not feel personally affected by climate change (see table A4.1 in the appendix). Table A4.1 also shows that farmers in groups (2) and (3) tend to be younger than farmers in the group (1) Not aware of climate change.

Another important factor is education. Education is negative and significant for the farmers in the group (1) Not aware of climate change, meaning that education plays a vital role when it comes to climate change awareness and perceived affectedness. Besides, we can see that the transmigration program is negatively associated with the groups (1) Not aware of climate change and (3) Feel personally affected by climate change. More farmers who do not feel personally affected are transmigrant farmers compared to groups (1) and (3). 
When turning to the wealth indicators, we find that the farmers in the groups (1) Not aware of climate change and (3) Feel personally affected by climate change, have a lower asset index compared to the farmers that do not feel personally affected by climate change. We also find that the farmers in groups (1) and (3) cultivate more hectares of oil palms compared to farmers in the group (2) Do not feel personally affected by climate change.

Finally, looking at the experience of extreme weather events, we find slightly heterogeneous results indicating that farmers do not strongly associate the experience with extreme weather events directly with their climate change perceptions.

\begin{tabular}{|c|c|c|c|c|c|c|}
\hline & $\begin{array}{c}\text { Not aware } \\
\text { of climate } \\
\text { change } \\
\end{array}$ & $\begin{array}{c}\text { Feel } \\
\text { personally } \\
\text { affected }\end{array}$ & $\begin{array}{c}\text { Not aware } \\
\text { of climate } \\
\text { change } \\
\end{array}$ & $\begin{array}{c}\text { Feel } \\
\text { personally } \\
\text { affected }\end{array}$ & $\begin{array}{c}\text { Not aware of } \\
\text { climate } \\
\text { change }\end{array}$ & $\begin{array}{c}\text { Feel } \\
\text { personally } \\
\text { affected } \\
\end{array}$ \\
\hline & (1) & $(2)$ & (3) & $(4)$ & (5) & (6) \\
\hline \multicolumn{7}{|l|}{ Sociodemographics } \\
\hline $\begin{array}{l}\text { Age of household } \\
\text { head }\end{array}$ & $\begin{array}{l}0.05 * * \\
(0.02)\end{array}$ & $\begin{array}{l}0.03^{*} \\
(0.02)\end{array}$ & $\begin{array}{c}0.05^{* * *} \\
(0.02)\end{array}$ & $\begin{array}{l}0.03^{*} \\
(0.02)\end{array}$ & $\begin{array}{c}0.05^{* * *} \\
(0.02)\end{array}$ & $\begin{array}{l}0.03^{*} \\
(0.02)\end{array}$ \\
\hline $\begin{array}{l}\text { Education of } \\
\text { household head } \\
\text { (in years) }\end{array}$ & $\begin{array}{c}-0.10 * * * \\
(0.02)\end{array}$ & $\begin{array}{l}0.008 \\
(0.03)\end{array}$ & $\begin{array}{c}-0.08 * * * \\
(0.03)\end{array}$ & $\begin{array}{c}0.03 \\
(0.04)\end{array}$ & $\begin{array}{c}-0.09 * * * \\
(0.03)\end{array}$ & $\begin{array}{c}0.03 \\
(0.04)\end{array}$ \\
\hline $\begin{array}{l}\text { Transmigration } \\
\text { program (1/0) }\end{array}$ & $\begin{array}{l}-0.59 \\
(0.37)\end{array}$ & $\begin{array}{l}-0.53^{*} \\
(0.29)\end{array}$ & $\begin{array}{l}-0.64^{*} \\
(0.35)\end{array}$ & $\begin{array}{c}-0.58^{* *} \\
(0.25) \\
\end{array}$ & $\begin{array}{l}-0.66^{*} \\
(0.35)\end{array}$ & $\begin{array}{c}-0.56^{* *} \\
(0.22)\end{array}$ \\
\hline $\begin{array}{l}\text { Number of } \\
\text { household } \\
\text { members }\end{array}$ & $\begin{array}{c}0.21 \\
(0.13)\end{array}$ & $\begin{array}{c}0.16 \\
(0.13)\end{array}$ & $\begin{array}{l}0.25^{*} \\
(0.14)\end{array}$ & $\begin{array}{c}0.20 \\
(0.14)\end{array}$ & $\begin{array}{c}0.23 \\
(0.14)\end{array}$ & $\begin{array}{c}0.20 \\
(0.15)\end{array}$ \\
\hline Diversification & $\begin{array}{c}0.02 \\
(0.38)\end{array}$ & $\begin{array}{l}-0.05 \\
(0.30)\end{array}$ & $\begin{array}{c}0.05 \\
(0.39)\end{array}$ & $\begin{array}{l}-0.03 \\
(0.31)\end{array}$ & $\begin{array}{l}-0.003 \\
(0.37)\end{array}$ & $\begin{array}{l}-0.04 \\
(0.30)\end{array}$ \\
\hline \multicolumn{7}{|l|}{ Wealth indicators } \\
\hline $\begin{array}{l}\text { Hectares of oil } \\
\text { palms }\end{array}$ & & & $\begin{array}{l}0.07 * * \\
(0.03)\end{array}$ & $\begin{array}{l}0.07 * * \\
(0.04)\end{array}$ & $\begin{array}{l}0.07^{*} \\
(0.04)\end{array}$ & $\begin{array}{l}0.07 * * \\
(0.03)\end{array}$ \\
\hline Asset index & & & $\begin{array}{l}-0.54^{*} \\
(0.29)\end{array}$ & $\begin{array}{l}-0.56^{*} \\
(0.32)\end{array}$ & $\begin{array}{l}-0.55^{*} \\
(0.29)\end{array}$ & $\begin{array}{l}-0.56^{*} \\
(0.32)\end{array}$ \\
\hline $\begin{array}{l}\text { Other income } \\
\text { sources besides } \\
\text { agriculture }(1 / 0)\end{array}$ & & & $\begin{array}{l}-0.03 \\
(0.55)\end{array}$ & $\begin{array}{c}0.04 \\
(0.28)\end{array}$ & $\begin{array}{c}0.04 \\
(0.59)\end{array}$ & $\begin{array}{c}0.06 \\
(0.32)\end{array}$ \\
\hline \multicolumn{7}{|c|}{ Experience of extreme weather events } \\
\hline $\begin{array}{l}\text { Has been affected } \\
\text { by droughts in the } \\
\text { last five years }\end{array}$ & & & & & $\begin{array}{l}-0.006 \\
(0.28)\end{array}$ & $\begin{array}{l}0.05 \\
(0.29)\end{array}$ \\
\hline $\begin{array}{l}\text { Has been affected } \\
\text { by floods in the } \\
\text { last five years }\end{array}$ & & & & & $\begin{array}{c}0.47 \\
(0.31)\end{array}$ & $\begin{array}{c}0.09 \\
(0.39)\end{array}$ \\
\hline $\begin{array}{l}\text { Has been affected } \\
\text { by crop diseases in } \\
\text { the last five years }\end{array}$ & & & & & $\begin{array}{l}-0.10 \\
(0.41)\end{array}$ & $\begin{array}{l}-0.10 \\
(0.37)\end{array}$ \\
\hline Constant & $\begin{array}{l}-1.64 \\
(1.38)\end{array}$ & $\begin{array}{l}-0.62 \\
(0.90)\end{array}$ & $\begin{array}{l}-2.26^{*} \\
(1.23)\end{array}$ & $\begin{array}{l}-1.30 \\
(0.79)\end{array}$ & $\begin{array}{l}-2.71^{* *} \\
(1.14)\end{array}$ & $\begin{array}{l}-1.37 \\
(1.07)\end{array}$ \\
\hline $\mathrm{N}$ & 408 & 408 & 408 & 408 & 408 & 408 \\
\hline
\end{tabular}


Columns (1) to (6) show estimates from multinomial logit estimations;

Standard errors in parentheses and clustered at village level;

${ }^{*} p<0.1,{ }^{* *} p<0.05,{ }^{* * *} p<0.01$

Base category: (2) Do not feel personally affected by climate change

The results of the multinomial logit with the category (2) Not aware of climate change as a base category are presented in the appendix (table A1).

Table 4.4: Factors associated with climate change awareness and perceived affectedness

\subsection{Discussion and conclusion}

The expansion of the area under oil palm cultivation in Indonesia is associated with tremendous negative environmental effects (Feintrenie et al. 2010b; Gibson et al. 2011; Merten et al. 2016; Austin et al. 2017; Dislich et al. 2017). Through the loss of forest areas, large amounts of $\mathrm{CO}_{2}$ have been released into the air contributing to climate change (Campbell et al. 2017). In return, agriculture is negatively affected by climate change through an increase in frequency and severity of weather events such as floods and droughts (Paterson et al. 2013). Due to rising temperatures, the risk of crop diseases for the oil palms increases (Paterson et al. 2013). In this context, we measured climate change awareness and the perceived affectedness of small-scale oil palm farmers in Indonesia. For the analysis, we constructed three different groups for climate change perceptions and grouped each farmer into the respective group: (1) Not aware of climate change, (2) Do not feel personally affected by climate change, and (3) Feel personally affected by climate change. We then applied multinomial logit estimations to compare the groups regarding the determinants that are associated with being in the different groups. Our results show that among the sociodemographics age and education are relevant determinants associated with climate change awareness and perceived affectedness. Besides, we find that wealth is an important determinant associated with climate change awareness. Finally, we cannot find strong associations between the experience of extreme weather events and climate change perceptions among the farmers.

Overall, we learn that about three out of four farmers are aware of climate change and that a bit more than every second farmer feels personally affected by climate change. This is in line with findings from other studies (Ullah et al. 2019) and offers a starting point for future discussions regarding climate change adaptation strategies. When directly comparing the three groups with each other we find in line with other studies, e.g. Muttarak and Lutz (2014), that education is an important factor for climate change awareness and perceived affectedness which is the first step before taking adaptation measures. As shown in the study by Muttarak and Lutz (2014) formal education seems to be associated with access to information and wider social networks to retrieve relevant information as well as a higher risk awareness. 
A younger age also seems to be relevant for climate change awareness and perceived affectedness which is in line with findings from Simelton et al. (2013), Lee et al. (2015), and Poortinga et al. (2019). Farmers in the second and third group, who are younger compared to the farmers that are not aware of climate change, might be more flexible regarding their worldviews leading to a higher climate change awareness and perceived affectedness (Stevenson et al. 2014). In addition, they might be aware of climate change as part of their formal education, and/or might also be more adapted to the use of digital technologies, e.g. the internet (Wen et al. 2011) as an information source compared to older farmers that are not aware of climate change.

For the wealth indicators, our results show that the better-off farmers tend to be aware of climate change but feel less personally affected by it compared to those that are not aware of climate change. This is in line with previous findings (Simelton et al. 2013; Singh et al. 2017). While larger financial resources are associated with the capability to invest in different strategies, e.g. improved varieties, as well as having more and better access to training and relevant advice compared to the poorer farmers that often are not aware of climate change but who are less capable to cope with the effects of it or develop suitable adaptation strategies, our results show that the wealthier farmers are the ones that do not feel personally affected by climate change compared to the poorer farmers. Yet, we also find that the farmers who do not feel personally affected by climate change, cultivate fewer hectares of oil palms compared to the farmers that are not aware of climate change. But the effect sizes are rather small.

In the light of our results, we suggest two implications to consider. First, as education is positively associated with climate change awareness, it is essential to spread more relevant knowledge about climate change and its effects on agriculture and vice versa especially among those that are poorer with less access to education. Fostering such knowledge might create an understanding of the connection between agriculture and climate change and awareness among the farmers on the importance to adopt suitable adaptation strategies. Second, as the wealthier farmers seem to be better equipped towards the effects coming from climate change compared to poorer farmers that do not have the financial means, it is relevant to support them individually in taking measures by taking potential barriers such as the financial means, and different levels of knowledge of the farmers into consideration. This could be implemented with the help of extension agents in the region. 


\section{Appendix}

\begin{tabular}{|c|c|c|c|c|c|c|}
\hline & $\begin{array}{l}\text { Feel not } \\
\text { personally } \\
\text { affected }\end{array}$ & $\begin{array}{c}\text { Feel } \\
\text { personally } \\
\text { affected } \\
\end{array}$ & $\begin{array}{c}\text { Feel not } \\
\text { personally } \\
\text { affected }\end{array}$ & $\begin{array}{c}\text { Feel } \\
\text { personally } \\
\text { affected }\end{array}$ & $\begin{array}{l}\text { Feel not } \\
\text { personally } \\
\text { affected }\end{array}$ & $\begin{array}{c}\text { Feel } \\
\text { personally } \\
\text { affected } \\
\end{array}$ \\
\hline & (1) & (2) & (3) & (4) & (5) & (6) \\
\hline \multicolumn{7}{|c|}{ Sociodemographics } \\
\hline $\begin{array}{l}\text { Age of } \\
\text { household head }\end{array}$ & $\begin{array}{c}-0.05^{* *} \\
(0.02) \\
\end{array}$ & $\begin{array}{l}-0.02 \\
(0.01) \\
\end{array}$ & $\begin{array}{c}-0.05^{* * *} \\
(0.02)\end{array}$ & $\begin{array}{l}-0.02 \\
(0.01) \\
\end{array}$ & $\begin{array}{c}-0.05^{* * *} \\
(0.02)\end{array}$ & $\begin{array}{l}-0.02 * \\
(0.01)\end{array}$ \\
\hline $\begin{array}{l}\text { Education of } \\
\text { household head } \\
\text { (in years) }\end{array}$ & $\begin{array}{c}0.10^{* * *} \\
(0.02)\end{array}$ & $\begin{array}{c}0.11^{* * *} \\
(0.02)\end{array}$ & $\begin{array}{c}0.08^{* * *} \\
(0.03)\end{array}$ & $\begin{array}{c}0.11^{* * *} \\
(0.02)\end{array}$ & $\begin{array}{c}0.09 * * * \\
(0.03)\end{array}$ & $\begin{array}{c}0.11^{* * *} \\
(0.03)\end{array}$ \\
\hline $\begin{array}{l}\text { Transmigration } \\
\text { program }(1 / 0)\end{array}$ & $\begin{array}{c}0.59 \\
(0.37) \\
\end{array}$ & $\begin{array}{c}0.06 \\
(0.32) \\
\end{array}$ & $\begin{array}{l}0.64^{*} \\
(0.35) \\
\end{array}$ & $\begin{array}{c}0.06 \\
(0.33) \\
\end{array}$ & $\begin{array}{l}0.66^{*} \\
(0.35) \\
\end{array}$ & $\begin{array}{c}0.10 \\
(0.32) \\
\end{array}$ \\
\hline $\begin{array}{l}\text { Number of } \\
\text { household } \\
\text { members }\end{array}$ & $\begin{array}{l}-0.21 \\
(0.13)\end{array}$ & $\begin{array}{l}-0.04 \\
(0.09)\end{array}$ & $\begin{array}{l}-0.25^{*} \\
(0.14)\end{array}$ & $\begin{array}{l}-0.05 \\
(0.09)\end{array}$ & $\begin{array}{l}-0.23 \\
(0.15)\end{array}$ & $\begin{array}{l}-0.04 \\
(0.09)\end{array}$ \\
\hline Diversification & $\begin{array}{l}-0.02 \\
(0.38) \\
\end{array}$ & $\begin{array}{l}-0.08 \\
(0.16) \\
\end{array}$ & $\begin{array}{l}-0.05 \\
(0.39) \\
\end{array}$ & $\begin{array}{l}-0.08 \\
(0.16) \\
\end{array}$ & $\begin{array}{l}0.003 \\
(0.37) \\
\end{array}$ & $\begin{array}{l}-0.03 \\
(0.16) \\
\end{array}$ \\
\hline \multicolumn{7}{|l|}{ Wealth indicators } \\
\hline $\begin{array}{l}\text { Hectares of oil } \\
\text { palms }\end{array}$ & & & $\begin{array}{c}-0.07 * * \\
(0.03) \\
\end{array}$ & $\begin{array}{l}-0.003 \\
(0.02)\end{array}$ & $\begin{array}{l}-0.07^{*} \\
(0.04)\end{array}$ & $\begin{array}{l}-0.003 \\
(0.02)\end{array}$ \\
\hline Asset index & & & $\begin{array}{l}0.54^{*} \\
(0.29) \\
\end{array}$ & $\begin{array}{l}-0.02 \\
(0.22) \\
\end{array}$ & $\begin{array}{l}0.55^{*} \\
(0.29) \\
\end{array}$ & $\begin{array}{l}-0.02 \\
(0.17) \\
\end{array}$ \\
\hline $\begin{array}{l}\text { Other income } \\
\text { sources besides } \\
\text { agriculture }(1 / 0)\end{array}$ & & & $\begin{array}{c}0.03 \\
(0.55)\end{array}$ & $\begin{array}{c}0.07 \\
(0.41)\end{array}$ & $\begin{array}{l}-0.04 \\
(0.59)\end{array}$ & $\begin{array}{c}0.02 \\
(0.40)\end{array}$ \\
\hline \multicolumn{7}{|c|}{ Experience of extreme weather events } \\
\hline $\begin{array}{l}\text { Has been } \\
\text { affected by } \\
\text { droughts in the } \\
\text { last five years }\end{array}$ & & & & & $\begin{array}{l}0.006 \\
(0.28)\end{array}$ & $\begin{array}{c}0.06 \\
(0.17)\end{array}$ \\
\hline $\begin{array}{l}\text { Has been } \\
\text { affected by } \\
\text { floods in the last } \\
\text { five years }\end{array}$ & & & & & $\begin{array}{l}-0.47 \\
(0.31)\end{array}$ & $\begin{array}{c}-0.39 * * \\
(0.15)\end{array}$ \\
\hline $\begin{array}{l}\text { Has been } \\
\text { affected by crop } \\
\text { diseases in the } \\
\text { last five years }\end{array}$ & & & & & $\begin{array}{c}0.10 \\
(0.41)\end{array}$ & $\begin{array}{c}-0.004 \\
(0.21)\end{array}$ \\
\hline Constant & $\begin{array}{c}1.64 \\
(1.38) \\
\end{array}$ & $\begin{array}{c}1.02 \\
(1.18) \\
\end{array}$ & $\begin{array}{l}2.26^{*} \\
(1.23) \\
\end{array}$ & $\begin{array}{c}0.96 \\
(1.21) \\
\end{array}$ & $\begin{array}{l}2.71^{* *} \\
(1.14) \\
\end{array}$ & $\begin{array}{c}1.34 \\
(1.31) \\
\end{array}$ \\
\hline $\mathrm{N}$ & 408 & 408 & 408 & 408 & 408 & 408 \\
\hline \multicolumn{7}{|c|}{$\begin{array}{l}\text { Columns (1) to (6) show estimates from multinomial logit estimations; } \\
\text { Standard errors in parentheses and clustered at village level; } \\
{ }^{*} p<0.1,{ }^{* *} p<0.05,{ }^{* * *} p<0.01 ; \\
\text { Base category: (1) Not aware of climate change }\end{array}$} \\
\hline
\end{tabular}

Table A4.1: Factors associated with climate change awareness and perceived affectedness 


\section{Conclusion}

In the last decades, the area under oil palm cultivation worldwide has increased. Between the 1970s and 2019, it has increased by almost nine times from 3.3 million hectares to 28.3 million hectares (FAOStat 2021). While this has brought economic benefits for many along the value chain, the oil palm boom also had negative effects on the environment (Koh and Wilcove 2008; Obidzinski et al. 2012; Lee et al. 2014; Sjahza and Asmit 2019). Among the economic benefits are income increases and an improvement of living standards of the oil palm farmers (Gatto et al. 2015). These are, however, not equally distributed among the farmers as they often depend on land, labor, capital endowments, and market economy exposure (Euler et al. 2017; Krishna et al. 2017; Santika et al. 2019). The negative environmental effects include loss of forest areas, a decrease in biodiversity, and water and air pollution affecting the local population (Feintrenie and Levang 2009; Gibson et al. 2011; Merten et al. 2016; Austin et al. 2017; Dislich et al. 2017; Santika et al. 2019). Deforestation which is often necessary to clear land for establishing new plantations implies that large amounts of $\mathrm{CO}_{2}$ are released into the atmosphere (Campbell et al. 2017) and hence, contributes to climate change. At the same time, climate change negatively affects oil palm cultivation through an increased occurrence and severity of extreme weather events as well as increased temperatures negatively affecting oil palm cultivation and livelihoods (Arora 2019; WMO 2020). Furthermore, these repercussions affect environmental concern and the engagement in pro-environmental behavior of the local population. Environmental concern and pro-environmental behavior themselves can influence future decisions about the (sustainable) use of natural resources (Meinhold and Malkus 2005).

In this dissertation, we focus on the economic and ecological trade-offs in the oil palm sector. Furthermore, this dissertation addresses the environmental dimension of oil palm cultivation by examining climate change perceptions, environmental concern, and pro-environmental behavior among the local population. We have three research objectives: first, to assess the adoption decisions of an agricultural technology that generates positive environmental effects among small-scale oil palm farmers to support sustainable oil palm cultivation; second, to understand the environmental concern and pro-environmental behavior among the local population in a setting characterized by a rapid landuse transformation in the Global South; and, third, to understand climate change perceptions among small-scale oil palm farmers. 


\subsection{Main findings and policy implications}

The research objective in essay one assesses the adoption decisions of an agricultural technology that generates positive environmental effects among small-scale oil palm farmers to support sustainable oil palm cultivation. The first essay compares two policy interventions to foster native tree planting in an oil palm cultivating hot spot in Indonesia. The results show that information about native tree planting and a subsidy for three tree seedlings increase the adoption of native tree planting compared to the price treatment where oil palm farmers received the same information and had the opportunity to buy three tree seedlings through an auction mechanism. The number of tree seedlings that were still alive after six months was higher for the farmers in the subsidy treatment. For additional planting efforts, we find that the subsidy tends to decrease additional planting efforts amongst farmers. The costs for the subsidy treatment are higher compared to the price treatment. The cost-effectiveness analysis reflects no difference between the subsidy and the price treatment when only considering the three native tree seedlings that we distributed through the two interventions. When including additional planting efforts, the price treatment is more cost-effective. Only a small number of farmers engage in additional planting. This might reflect low preferences for native trees and limited market access. Our data support this finding, as the average WTP that farmers offered in the price treatment is below the average market price of tree seedlings. Finally, the majority of the farmers that we interviewed stated not having enough information available in their villages about native tree planting.

The results from our first essay show that subsidies are good options to reach large numbers of farmers. Our results are consistent with previous studies (Jack et al. 2015; Rudolf et al. 2020). Subsidies also provide an opportunity to influence the tree species farmers plant and the degree of biodiversity. Yet, subsidies tend to crowd out additional planting activities and the subsidy treatment is less costeffective compared to the price treatment when including additional planting efforts. This is an important factor to consider from a policy perspective when it comes to funding. Overall, relatively few farmers decide to invest in additional tree seedlings reflecting an environmental-economic tradeoff among the farmers, as they might fear yield decreases when deciding to plant trees, especially in their oil palm plantations. Hence, to attract a larger number of farmers to adopt tree planting and to address several barriers to native tree planting, a mix of the two interventions might be most suitable.

With these results in mind, the following policy recommendations can be drawn from the first essay: First, value chain development for tree seedlings is crucial to enhance market access to high-quality tree seedlings in rural areas. This could include building and supporting local nurseries for native tree species. With a larger quantity and good quality of native tree seedlings locally available, prices for tree seedlings could drop. This price drop could decrease the existing gap between the WTP of the farmers and the high market prices that farmers have to pay at the moment. Second, to increase 
farmers' WTP for native tree seedlings, knowledge and first-hand experience with tree seedlings are needed. Extension services could play a vital role here by conducting trainings for farmers, e.g. on how to plant and maintain tree seedlings. Another option could be to establish farmer field schools where the farmers establish a "learning field" where they mix oil palms with native trees and accompany the tree growth and take care of them. Finally, we recommend policymakers to combine the value chain development with subsidized tree seedlings. This way, many farmers can be reached and start to experiment with the trees. In-kind subsidies might help to overcome the farmers' WTP-market price gap and policymakers would have better control over the varieties of native trees being planted. As funding for such interventions is limited and cost-effectiveness is important, value chain development could reduce the funds needed for fostering native tree planting among the farmers.

The second essay of this dissertation focuses on the EC and PEB among the local population in a rapid land-use transforming setting in the Global South. This essay investigates determinants of EC and PEB of residents that live in an oil palm cultivation hotspot with a special focus on geographical residence. The results show that, overall, the rural residents who are directly involved in oil palm cultivation are more concerned about the environment compared to the urban residents. Not only is this the case for the general EC but also the more specific oil palm-related concern. Oil palm farmers seem to be aware of the negative environmental effects of oil palm cultivation. Furthermore, environmental perceptions such as the connectedness to nature, connectedness with oil palms, and preferences for diversified landscapes are correlated with EC. PEB was measured with donations made to a local environmental organization. Results reveal that EC and PEB are strongly correlated with each other. In addition, the rural residents made significantly higher donations than the urban residents suggesting that EC might act as a mediator. Finally, the hours participated in other environmental activities are positively correlated with PEB while connectedness with oil palms negatively.

With significant differences for EC and PEB among the urban and rural residents, the second essay indicates that there might be a lack of connectedness between the large-scale agrarian transformation that has been taking place in Indonesia for decades and the negative environmental effects generated by oil palm cultivation. This seems to be especially relevant for urban residents. In comparison, the rural residents seem to be aware of the negative environmental effects related to oil palm. While this concern does not necessarily translate into action, the results also show that EC and PEB are positively correlated among all residents.

We suggest the following policy recommendations: First, making use of the fact that oil palm farmers seem to be aware of the negative environmental effects of oil palm cultivation offers an entry point for discussions. This could lead to the planning of interventions to support the farmers in engaging in PEB. Second, local governments could launch programs for environmental education and information 
to foster EC and PEB. This is especially relevant among the urban residents that do not connect agriculture with the environment. This approach seems to be promising since EC and PEB are positively correlated in our study for rural and urban residents.

The third essay addresses climate change perceptions of small-scale oil palm farmers. We analyzed the determinants that are associated with climate change awareness and perceived affectedness by smallscale oil palm farmers. Our results reveal that almost 75 percent of all respondents have heard about climate change and about 60 percent feel personally affected by it. The results show that age, education, and wealth are important determinants that are associated with climate change perceptions. Finally, we find that the experience with extreme weather events is not strongly associated with the climate change perceptions of the oil palm farmers.

The fact that roughly three out of four farmers have heard about climate change offers a good starting point for discussions regarding adaptation strategies. Further, we find that age, education, and wealth matter when it comes to climate change awareness and perceived affectedness which is in line with previous research (Simelton et al. 2013; Muttarak and Lutz 2014; Lee et al. 2015; Singh et al. 2017; Poortinga et al. 2019). Younger farmers might have more flexible worldviews, leading to a higher climate change awareness compared to older farmers (Stevenson et al. 2014). More educated farmers seem to have more access to information and have wider social networks, allowing them to retrieve relevant information (Muttarak and Lutz 2014). The wealthier farmers in our study tend to be more aware of climate change, but they are not necessarily the ones who feel personally affected by climate change.

In light of the results from the third essay, we suggest the following policy recommendations: First, as we find that education is positively associated with climate change awareness, more knowledge about the effects of climate change on agriculture, and vice versa, is needed, especially, among those that have less access to education. Knowledge on climate change might ultimately create an understanding of the connection between climate change and agriculture and hence, the importance to adopt adaptation strategies. Second, we have seen that wealthier farmers seem to be better equipped for adapting to the effects of climate change compared to poorer farmers. Therefore, it is relevant to support farmers individually to adopt adaptation measures taking potential barriers such as costs for certain measures, financial means, and different levels of knowledge into account. This could be implemented with the support of the local extension agents. 


\subsection{Limitations and scope for future research}

In the first essay, we analyzed and compared two policy interventions to foster tree planting among small-scale oil palm farmers. After our intervention, we reinterviewed the farmers to understand what happened with the tree seedlings half a year later. A time span of six months offers the time to capture some planting and initial evidence on tree survival. Yet, it is probably not enough time to adequately reflect further investments into trees by the farmers. Especially for the farmers with no prior experience with trees, it might take some time to experiment with the trees and gain experience to make informed decisions about investments into trees in the future. Upon our return, many farmers had not yet planted their tree seedlings and wanted to delay the planting for some more months. Hence, looking at the tree seedlings after at least one year would allow drawing more precise conclusions.

In this essay, we described the potential benefits of tree planting for the environment. However, we did not collect any measures ourselves to further support the literature. We were not able to assess the ecological benefits of the trees that the farmers planted. The farmers in our experiment received only a small number of tree seedlings. Even though planting a small number of tree seedlings can improve the delivery of ecosystem functions, it is not exactly clear what ecological effects could be generated. Future research might work with planting different numbers of native trees in farm landscapes to better understand whether the number of trees given to a farmer affects the farmers' decisions on where to plant trees and how many. In doing so, the ecological effects generated can also be measured. As mentioned, native tree planting supports income diversification. As we collected the follow-up data after six months, we were not able to measure any income diversification effects of the trees. Hence, checking on the trees after a longer time span might allow collecting data on the income diversification strategies of the farmers. Finally, the farmers that participated in the two interventions might have realized that they participate in an experiment and adapted their behavior accordingly, known as the Hawthorne effect. To reduce this effect to the extent possible, we did not inform the farmers during the first interview that we were planning to visit them again to reinterview them about the tree seedlings.

The second essay analyzed EC and PEB among residents that live in an oil palm cultivating hotspot. To measure PEB, we implemented a donation game. The endowment each respondent received to be split between himself/herself and the environmental organization was unearned. This unearned endowment could have led to a higher share given to the environmental organization compared to when the endowment to be split was earned before. Furthermore, we could not guarantee full anonymity during our donation game. Our allocators might not have believed that they can make their decision anonymously or they might have felt observed. This could have led to donate a higher amount 
due to reputation, social desirability, or reciprocity. Yet, the literature suggests that missing privacy only has a small effect on the allocator's actual behavior (Winking 2014). As these two framework conditions were the case for both, the rural and the urban residents, we did not expect a bias among our results but rather expected an overestimation of them.

We measured EC and PEB for rural and urban residents in Jambi, Indonesia. The rural residents consisted all of oil palm farmers. Hence, we were not able to distinguish between the associations of different occupations and geographical residence on EC separately as only a few urban residents are involved in agriculture. The same issue arises for the analysis of PEB. Hence, future research could further distinguish between different occupation groups, for example, along the urban-rural gradient and analyze EC and PEB, especially in such a unique scenario in the Global South, to receive a more nuanced picture of EC and PEB.

The third essay measured climate change perceptions of small-scale oil palm farmers. To get a more nuanced picture of the determinants for climate change awareness and the perceived affectedness of the farmers, information such as the number of experienced extreme weather events and weather data (precipitation) would have been valuable. Unfortunately, such data was not available. It might also be of interest for future research to not only include more detailed weather data but also to include data on specific adaptation strategies that farmers already adopt to analyze the relationship between climate change perceptions and actual adaptation measures taken by the farmers.

Due to the Covid-19 pandemic, another field trip to Indonesia in 2020 was not feasible. For this last field trip, data collection was planned for the third paper as well as for the EFForTS wide landscape assessment. For the third paper, we wanted to implement a choice experiment with oil palm farmers. The objective was to simulate a hypothetical PES scheme that aims at supporting a more sustainable land use by planting native trees in oil palm plantations. More specifically, farmers could have chosen between different options. These included the planting structure, the number of different tree varieties planted, the intensity, a monitoring option, and a compensation for adopting these options (measured in IDR). As we have not been able to continue working on this idea, it would be of great interest to further refine this idea and implement it.

As mentioned at the beginning of this dissertation, for Indonesia, maintaining the economic viability of oil palms while developing strategies to address the negative environmental effects remains a major challenge (Zhao et al. 2006). This dissertation addressed the environmental and economic dimensions of oil palm cultivation and shows that there exist economic-environmental trade-offs. While many oil palm farmers seem to be aware of the negative environmental effects from oil palms this does not necessarily lead to the engagement in adaptive behavior to address these environmental 
repercussions. Identified barriers include knowledge gaps and market inefficiencies. Citizens from Jambi City, who may not be directly involved in oil palm cultivation, do not necessarily connect the agrarian transformation with the negative environmental effects. To support sustainable land use, the economic and environmental dimensions of oil palm cultivation need to be further addressed. Thereby, the social dimension has to be considered as well, which makes sustainable oil palm an even more complex challenge. Finally, it is important to take all stakeholders along the oil palm value chain into account. 


\section{References}

Acharya, K.P., 2006. Linking trees on farms with biodiversity conservation in subsistence farming systems in Nepal. Biodiversity and Conservation 15(2), 631-646.

https://doi.org/10.1007/s10531-005-2091-7

Ajzen, I. 1989. Attitude structure and behavior in Pratkanis, A.R., Beckler, S.J. and Greenwald, A.G. (Eds), Attitude Structure and Function, Lawrence Erlbaum, Hillsdale, NJ, 241-274.

Aker, J.C., 2011. Dial "A" for Agriculture: A Review of Information and Communication Technologies for Agricultural Extension in Developing Countries. Agricultural Economics 42(6), 631-647. https://doi.org/10.1111/j.1574-0862.2011.00545.x

Arendt, F., and Matthes, J., 2016. Nature Documentaries, Connectedness to Nature, and Proenvironmental Behavior. Environmental Communication, 10(4), 453-472. https://doi.org/10.1080/17524032.2014.993415

Aron, A. Aron, E.N., Smollan, D., 1992. Inclusion of other in the self-scale and the structure of interpersonal closeness. Journal of Personality and Social Psychology 63(4), 596-612. https://doi.org/10.1037/0022-3514.63.4.596

Arora, N.K., 2019. Impact of climate change on agriculture production and its sustainable solutions. Environmental Sustainability, 2(2), 95-96. https://doi.org/10.1007/s42398-019-00078-w

Arriagada, R.A., Sills, E.O., Ferraro, P.J., Pattanayak, S.K., 2015. Do payments pay off? Evidence from participation in Costa Rica's PES program. PLoS ONE 10(7). https://doi.org/10.1371/journal.pone.0131544

Asfaw, S., Kassie, M., Simtowe, F., Lipper, L., 2012. Poverty Reduction Effects of Agricultural Technology Adoption: A Micro-evidence from Rural Tanzania. Journal of Development Studies 48(9), 1288-1305. https://doi.org/10.1080/00220388.2012.671475

Ashraf, N., Berry, J., Shapiro, J.M., 2010. Can Higher Prices Stimulate Product Use? Evidence from a Field Experiment in Zambia. American Economic Review 100(5), 2383-2413. https://doi.org/10.1257/aer.100.5.2383

Atiqah, N., Yahya, M.S., Aisyah, S., Ashton-Butt, A., Azhar, B., 2019. Birds associated with different tree species and structures in oil palm agroforestry landscapes in Malaysia. Emu - Austral Ornithology 119(4), 397-401. https://doi.org/10.1080/01584197.2019.1621680

Austin, K.G., Kasibhatla, P.S., Urban, D.L., Stolle, F., Vincent, J., 2015. Reconciling Oil Palm Expansion and Climate Change Mitigation in Kalimantan, Indonesia. PLoS ONE 10(5), e0127963. https://doi.org/10.1371/journal.pone.012796

Austin, K.G., Mosnier, A., Pirker, J., McCallum, I., Fritz, S., Kasibhatla, P.S., 2017. Shifting patterns of oil palm driven deforestation in Indonesia and implications for zero-deforestation commitments. Land Use Policy 69, 41-48. https://doi.org/10.1016/j.landusepol.2017.08.036 
Baptiste, A.K., Nordenstam, B.J., 2009. Impact of oil and gas drilling in Trinidad: Factors influencing environmental attitudes and behaviours within three rural wetland communities. Environmental Conservation 36, 14-21. https://doi.org/10.1017/S0376892909005268

Bardsley, N., 2008. Dictator game giving: Altruism or artefact? Experimental Economics 11(2), $122-$ 133. https://doi.org/10.1007/s10683-007-9172-2

Basiron, Y., Weng, C.K., 2004. The oil palm and its sustainability. Journal of Oil Palm Research 16(1), 1-10.

Baulch, B., Quisumbing, A., 2011. Testing and adjusting for attrition in household panel data. CPRC Toolkit Note, Manchester: Chronic Poverty Research Centre.

Becker, G., DeGroot, M., Marschak, J., 1964. Measuring utility by a single-response sequential method. Behavioral Science 9, 226-236. https://doi.org/10.1002/bs.3830090304

Bekkers, R., 2007. Measuring Altruistic Behavior in Surveys: The All-or-Nothing Dictator Game. Survey Research Methods 1(3), 139-144. https://doi.org/10.18148/srm/2007.v1i3.54

Bellemare, M.F., Wichman, C.J., 2019. Elasticities and the Inverse Hyperbolic Sine Transformation. Oxford Bulletin of Economics and Statistics 82(1), 50-61. https://doi.org/10.1111/obes.12325

Belotti, F., Deb, P., Manning, W.G., Norton, E.C., 2015. twopm: Two-part models. Stata Journal 15(1), 3-20. https://doi.org/10.1177/1536867X1501500102

Bensch, G., Peters, J., 2017. One-off Subsidies and Long-Run Adoption-Experimental Evidence on Improved Cooking Stoves in Senegal. American Journal of Agricultural Economics 102(1), 72-90. https://doi.org/10.1093/ajae/aaz023

Berenguer, J., Corraliza, J. A., Martin, R., 2005. Rural-Urban differences in environmental concern, attitudes, and actions. European Journal of Psychological Assessment, 21(2), 128-138. https://doi.org/10.1027/1015-5759.21.2.128

Berry, J., Fischer, G., Guitera, R., 2020. Eliciting and Utilizing Willingness-to-Pay: Evidence from Field Trials in Northern Ghana. Journal of Political Economy 128, 1436-1473. https://doi.org/10.1086/705374

Bogner, F.X., Wiseman, M., 1997. Environmental Perception of Rural and Urban Pupils. Journal of Environmental Psychology 17, 111-122. https://doi.org/10.1006/jevp.1997.0046

Bohensky, E.L., Smajgl, A., Brewer, T., 2013. Patterns in household-level engagement with climate change in Indonesia. Nature Climate Change 3, 348-351. https://doi.org/10.1038/nclimate1762

Bolderdijk, J. W., Steg, L., Geller, E. S., Lehman, P. K., Postmes, T., 2013. Comparing the effectiveness of monetary versus moral motives in environmental campaigning. Nature Climate Change, 3(4), 413-416. https://doi.org/10.1038/nclimate1767 
Bou Dib, J., Krishna, V.V., Alamsyah, V., Qaim, M., 2018. Land-Use Change and Livelihoods of Nonfarm Households: The Role of Income from Employment in Oil Palm and Rubber in Rural Indonesia. Land Use Policy 76, 828-38. https://doi.org/10.1016/j.landusepol.2018.03.020

BPS-Statistics Indonesia, 2019. Indonesian Oil Palm Statistics. Indonesian Central Bureau of Statistics

Budidarsono, S., Susanti, A., Zoomers, A., 2013. Oil Palm Plantations in Indonesia: The Implications for Migration, Settlement/Resettlement and Local Economic Development. Biofuels - Economy, Environment and Sustainability. InTech. https://doi.org/10.5772/53586

Butler, R.A., Koh, L.P., Ghazoul, J., 2009. REDD in the red: palm oil could undermine carbon payment schemes. Conservation Letters 2(2), 67-73. https://doi.org/10.1111/j.1755-263x.2009.00047.x

Cameron, A.C., Trivedi, P., 1986. Econometric Models Based on Count Data: Comparisons and Applications of Some Estimators and Tests. Journal of Applied Econometrics 1(1), 29-53. https://doi.org/10.1002/jae.3950010104

Campbell, B.M., Beare, D.J., Bennett, E.M., Hall-Spencer, J.M., Ingram, J.S.I., Jaramillo, F., Ortiz, R., Ramankutty, N., Sayer, J.A., Shindell, D., 2017. Agriculture production as a major driver of the earth system exceeding planetary boundaries. Ecology and Society 22(4), 8. https://doi.org/10.5751/ES-09595-220408

Campenhout, B. Van., 2019. The Role of Information in Agricultural Technology Adoption: Experimental Evidence from Rice Farmers in Uganda. Economic Development and Cultural Change. https://doi.org/10.1086/703868

Carlson, K.M., Curran, L.M., Ratnasari, D., Pittman, A.M., Soares-Filho, B.S., Asner, G.P., Trigg, S.N., Gaveau, D.A., Lawrence, D., Rodrigues, H.O., 2012. Committed carbon emissions, deforestation, and community land conversion from oil palm plantation expansion in West Kalimantan, Indonesia. Proceedings of the National Academy of Sciences U. S. A. 109, 7559-7564. https://doi.org/10.1073/pnas.1200452109

Chazdon, R.L., 2008. Beyond deforestation: Restoring forests and ecosystem services on degraded lands. Science 320, 1458-1460. https://doi.org/10.1126/science.1155365

Chileshe, B., Sampa Moonga, M., 2019. Disparities in Pro-Environmental Behaviour between Rural and Urban Areas in Zambia. International Journal of Humanities Social Sciences and Education, 4 (6), 196-215.

Clark, C.F., Kotchen, M.J., Moore, M.R., 2003. Internal and external influences on pro-environmental behavior: Participation in a green electricity program. Journal of Environmental Psychology, 23(3), 237-246. https://doi.org/10.1016/S0272-4944(02)00105-6

Cohen, J., Dupas, P., 2010. Free distribution or cost-sharing? Evidence from a randomized malaria prevention experiment. Quarterly Journal of Economics 125(1), 1-45. https://doi.org/10.1162/qjec.2010.125.1.1

Cole, R. J., 2010. Social and environmental impacts of payments for environmental services for agroforestry on small-scale farms in southern Costa Rica. International Journal of Sustainable 
Development and World Ecology, 17(3), 208-216. https://doi.org/10.1080/13504501003729085

Cole, R.J., Holl, K.D., Zahawi, R.A., 2010. Seed rain under tree islands planted to restore degraded lands in a tropical agricultural landscape. Ecological Applications, 20(5), 1255-1269. https://doi.org/10.1890/09-0714.1

Corley, R.H.V., Tinker P.B., 2016. The Oil Palm. Chichester, West Sussex, UK: Wiley Blackwell. 5th ed.

Cornelis, I., Van Hiel, A., Roets, A., Kossowska, M., 2009. Age differences in conservatism: Evidence on the mediating effects of personality and cognitive style. Journal of Personality $77,51-88$. https://doi.org/10.1111/j.1467-6494.2008.00538.x

Corral-Verdugo, V., 1997. Dual "realities" of conservation behavior: Self-reports vs observations of re-use and recycling behavior. Journal of Environmental Psychology 17(2), 135-145. https://doi.org/10.1006/jevp.1997.0048

Cotten, S.R., Gupta, S.S., 2004. Characteristics of online and offline health information seekers and factors that discriminate between them. Social Science \& Medicine 59, 1795-1806. https://doi.org/10.1016/j.socscimed.2004.02.020

DeFries, R.S., Rudel, T., Uriarte, M., Hansen, M., 2010. Deforestation driven by urban population growth and agricultural trade in the twenty-first century. Nature Geoscience 3, 178-181. https://doi.org/10.1038/ngeo756

Derksen, L., Gartrell, J., 1993. The Social Context of Recycling. American Sociological Review 58(3), 434-442. https://doi.org/10.2307/2095910

Dhanya, P., Ramachandran, A., 2015. Farmers' perceptions of climate change and the proposed agriculture adaptation strategies in a semi arid region of south India. Journal of Integrative Environmental Sciences, 13(1), 1-18. https://doi.org/10.1080/1943815X.2015.1062031

Dislich, C., Keyel, A.C., Salecker, J., Kisel, Y., Meyer, K.M., Auliya, M., Barnes, A.D., Corre, M.D., Darras, K., Faust, H., Hess, B., Klasen, S., Knohl, A., Kreft, H., Meijide, A., Nurdiansyah, F., Otten, F., Pe'er, G., Steinebach, S., Tarigan, S., Tölle, M.H., Tscharntke, T., Wiegand, K., 2017. A review of the ecosystem functions in oil palm plantations, using forests as a reference system. Biological Reviews, 92(3), 1539-1569. https://doi.org/10.1111/brv.12295

Duflo, E., Kremer, M., Robinson, J., 2010. Nudging Farmers to Use Fertilizer: Theory and Experimental Evidence from Kenya. American Economic Review 101(6), 2350-2390. https://doi.org/10.1257/aer.101.6.2350

Dumville, J.C., Torgerson, D.J., Hewitt, C.E., 2006. Reporting attrition in randomised controlled trials. British Medical Journal 332(7547), 969-971. https://doi.org/10.1136/bmj.332.7547.969

Dunlap, R.E., Van Liere, K.D., Mertig, A.G., Jones, R.E., 2003. New Trends in Measuring Environmental Attitudes: Measuring Endorsement of the New Ecological Paradigm: A Revised NEP Scale. Journal of Social Issues 56(3), 425-442. https://doi.org/10.1111/0022-4537.00176 
Dupas, P., 2014. Short-Run Subsidies and Long-Run Adoption of New Health Products: Evidence From a Field Experiment. Econometrica 82(1), 197-228. https://doi.org/10.3982/ecta9508

Dutcher, D.D., Finley, J.C., Luloff, A.E., Johnson, J.B., 2007. Connectivity with nature as a measure of environmental values. Environment and Behavior 39(4), 474-493. https://doi.org/10.1177/0013916506298794

Eckel, C.C., Grossman, P.J., Andreoni, J., Ball, S., Gilles, R., Goodman, A., Hoffman, E., 1996. Altruism in Anonymous Dictator Games. Games and Economic Behavior 16, 181-191. https://doi.org/10.1006/game.1996.0081

Euler, M., Hoffmann, M.P., Fathoni, Z., Schwarze, S., 2016a. Exploring yield gaps in smallholder oil palm production systems in eastern Sumatra, Indonesia. Agricultural Systems 146, 111-119. https://doi.org/10.1016/j.agsy.2016.04.007

Euler, M., Schwarze, S., Siregar, H., Qaim, M., 2016b. Oil Palm Expansion among Smallholder Farmers in Sumatra, Indonesia. Journal of Agricultural Economics, 67(3), 658-676. https://doi.org/10.1111/1477-9552.12163

Euler, M., Krishna, V.V., Schwarze, S., Siregar, H., Qaim, M., 2017. Oil palm adoption, household welfare, and nutrition among smallholder farmers in Indonesia. World Development 93, 219235. https://doi.org/10.1016/j.worlddev.2016.12.019

FAOSTAT, Crop Production Data (Rome, Food and Agricultural Organization of the United

Fargione, J., Hill, J., Tilman, D., Polasky, S., Hawthorne, P., 2008. Land clearing and the biofuel carbon debt. Science 319(5867), 1235-1238. https://doi.org/10.1126/science.1152747

Feintrenie, L., Levang, P., 2009. Sumatra's Rubber Agroforests; Advent, Rise and Fall of a Sustainable Cropping System. Small-scale Forestry 8(3), 323-335. https://doi.org/10.1007/s11842-0099086-2

Feintrenie, L., Chong, W.K., Levang, P., 2010a. Why do farmers prefer oil palm? lessons learnt from Bungo District, Indonesia. Small-Scale Forestry 9(3), 379-396. https://doi.org/10.1007/s11842010-9122-2

Feintrenie, L., Schwarze, S., Levang, P., 2010b. Are Local People Conservationists? Analysis of Transition Dynamics from Agroforests to Monoculture Plantations in Indonesia. Ecology and Society 15(4), 37. http://hdl.handle.net/10535/7437

Fitzgerald, J., Gottschalk, P., Moffitt, R., 1998. An analysis of sample attrition in panel data the Michigan panel study of income dynamics. Journal of Human Resources 33(2), 296-299. https://doi.org/10.2307/146433

Fitzherbert, E., Struebig, M., Moerl, A., Danielsen, F., Bruehl, C., Donald, P., Phalan, B., 2008. How will oil palm expansion affect biodiversity? Trends in Ecology and Evolution 23(10), 538-545. https://doi.org/10.1016/j.tree.2008.06.012 
Fransson, N., and Gärling, T., 1999. Environmental concern: Conceptual definitions, measurement methods, and research findings. Journal of Environmental Psychology, 19(4), 369-382. https://doi.org/10.1006/jevp.1999.0141

Franzen, A., Pointner, S., 2012. Anonymity in the dictator game revisited. Journal of Economic Behavior and Organization 81(1), 74-81. https://doi.org/10.1016/j.jebo.2011.09.005

Fujii, E.T., Hennessy, M., Mak, J., 1985. An evaluation of the validity and reliability of survey response data on household electricity conservation. Evaluation Review 9, 93-104. https://doi.org/10.1177/0193841X8500900106

Gatto, M., Wollni, M., Qaim, M., 2015. Oil Palm Boom and Land-Use Dynamics in Indonesia-The Role of Policies and Socioeconomic Factors. Land Use Policy 46, 292-303. https://doi.org/10.1016/j.landusepol.2015.03.001

Gérard, A., Wollni, M., Hölscher, D., Irawan, B., Sundawati, L., Teuscher, M., Kreft, H., 2017. Oil-palm yields in diversified plantations: Initial results from a biodiversity enrichment experiment in Sumatra, Indonesia. Agriculture, Ecosystems and Environment 240, 253-260. https://doi.org/10.1016/j.agee.2017.02.026

Gibson, L. Lee T.M., Koh, L.P., Brook, B.W., Gardner, T.A., Barlow, J., Peres, C.A., Bradshaw C.J.A., Laurance, W.F., Lovejoy, T.E., Sodhi, N.S., 2011. Primary forests are irreplaceable for sustaining tropical biodiversity. Nature 478(7369), 378-381. https://doi.org/10.1038/nature10425

Greene, W., 2012. Econometric Analysis. Seventh edition. Pearson

Greiner, R., Gregg, D., 2011. Farmers' intrinsic motivations, barriers to the adoption of conservation practices and effectiveness of policy instruments: Empirical evidence from northern Australia. Land Use Policy 28(1), 257-265. https://doi.org/10.1016/j.landusepol.2010.06.006

Hair, J.F., Black, W.C., Babin, B.J., Anderson, R.E., 2009. Multivariate data analysis: A global perspective. 7th edition. Upper Saddle River: Prentice Hall.

Hall, D., 2009. The 2008 World Development Report and the political economy of Southeast Asian agriculture. Journal of Peasant Studies 36(3), 603-609. https://doi.org/10.1080/03066150903142964

Hamilton, L.C., 1985. Self-Reported and Actual Savings in a Water Conservation Campaign. Environment and Behavior 17(3), 315-326. https://doi.org/10.1177/0013916585173003

Hilbe J.M., 2011. Negative Binomial Regression. Second edition. New York: Cambridge University Press

Hoffman, E., McCabe, K., Smith V.L., 1996. Social Distance and Other-Regarding Behavior in Dictator Games. The American Economic Review 86(3), 653-660. https://www.jstor.org/stable/2118218

Huddart-Kennedy, E., Beckley, T. M., McFarlane, B. L., Nadeau, S., 2009. Rural-urban differences in environmental concern in Canada. Rural Sociology, 74(3), 309-329.

https://doi.org/10.1526/003601109789037268 
Jack, B.K., 2013: Private Information and the Allocation of Land Use Subsidies in Malawi. American Economic Journal: Applied Economics 5(3), 113-135. https://doi.org/10.1257/app.5.3.113

Jack, B.K., Oliva, P., Severen, C., Walker, E., Bell, S., 2015: Technology Adoption Under Uncertainty: Take-Up and Subsequent Investment in Zambia. NBER Working Paper 21414, National Bureau of Economic Research, Cambridge, MA.

Jones, R.E., Fly, J.M., Cordell, H.K., 1999. How green is my valley? Tracking rural and urban environmentalism in the Southern Appalachian Ecoregion. Rural Sociology 64(3), 482-499. https://doi.org/10.1111/j.1549-0831.1999.tb00363.x

Kaltenborn, B.P., Bjerke, T., 2002. Associations between environmental value orientations and landscape preferences. Landscape and Urban Planning 59, 1-11. https://doi.org/10.1016/S0169 $-2046(01) 00243-2$

Khan, A., Khan, M.N., Adil, M., 2012. Exploring the New Ecological Paradigm (NEP) Scale in India: Item Analysis, Factor Structure and Refinement. Asia-Pacific Journal of Management Research and Innovation 8(4), 389-397. https://doi.org/10.1177/2319510x13477966

Knowler, D., Bradshaw, B., 2007. Farmers' adoption of conservation agriculture: A review and synthesis of recent research. Food Policy 32(1), 25-48. https://doi.org/10.1016/j.foodpol.2006.01.003

Koh, L.P., 2008. Can oil palm plantations be made more hospitable for forest butterflies and birds? Journal of Applied Ecology 45(4), 1002-1009. https://doi.org/10.1111/j.13652664.2008.01491.x

Koh, L.P., Wilcove, D.S., 2008. Is oil palm agriculture really destroying tropical biodiversity? Conservation Letters 1(2), 60-64. https://doi.org/10.1111/j.1755-263x.2008.00011.x

Koh, L.P., Ghazoul, J., 2010. Spatially explicit scenario analysis for reconciling agricultural expansion, forest protection, and carbon conservation in Indonesia. Proceedings of the National Academy of Sciences of the United States of America 107(24), 11140-11144. https://doi.org/10.1073/pnas.1000530107

Koh, L.P., Miettinen, J., Liew, S.C., Ghazoul, J., 2011. Remotely sensed evidence of tropical peatland conversion to oil palm. Proceedings of the National Academy of Sciences 108(12), 5127-5132. https://doi.org/10.1073/pnas.1018776108

Kollmuss, A., Agyeman, J., 2002. Mind the Gap: Why do people act environmentally and what are the barriers to pro-environmental behavior? Environmental Education Research 8(3), 239-260. https://doi.org/10.1080/13504620220145401

Köszegi, B., Rabin, M., 2006. A Model of Reference-Dependent Preferences. The Quarterly Journal of Economics 121(4), 1133-1165. https://doi.org/10.1093/qje/121.4.1133

Kotchen, M.J., Reiling, S.D., 2000. Environmental attitudes, motivations, and contingent valuation of nonuse values: a case study involving endangered species. Ecological Economics 32(1), 93-107. https://doi.org/10.1016/S0921-8009(99)00069-5 
Kremer, M. and Willis, J., 2016. Guns, latrines, and land reform: Dynamic pigouvian taxation. American Economic Review 106, 83-88. https://doi.org/10.1257/aer.p20161096

Krishna, V.V., Kubitza, C., Pascual, U., Qaim, M., 2017. Land markets, Property rights, and Deforestation: Insights from Indonesia. World Development 99, 335-349. https://doi.org/10.1016/j.worlddev.2017.05.018

Kubitza, C., Krishna, V.V., Alamsyah, Z., Qaim, M., 2018. The Economics Behind an Ecological Crisis: Livelihood Effects of Oil Palm Expansion in Sumatra, Indonesia. Human Ecology 46, 107-116. https://doi.org/10.1007/s10745-017-9965-7

Lasco R.D., Habito C.M.D., Delfino R.J.P., Pulhin F.B., Concepcion R., 2011. Climate change adaptation for smallholder farmers in Southeast Asia. Los Baños, Philippines: World Agroforestry Centre Philippines

Lee, J.S.H., Ghazoul, J., Obidzinski, K., Koh, L.P., 2014. Oil palm smallholder yields and incomes constrained by harvesting practices and type of smallholder management in Indonesia. Agronomy for Sustainable Development 34(2), 501-513. https://doi.org/10.1007/s13593-0130159-4

Lee, T.M., Markowitz, E.M., Howe, P.D., Ko, C.Y., Leiserowitz, A.A., 2015. Predictors of public climate change awareness and risk perception around the world. Nature Climate Change 5, 1014-1020. https://doi.org/10.1038/nclimate2728

Lim, C.I., Biswas, W., Samyudia, Y., 2015. Review of existing sustainability assessment methods for Malaysian palm oil production. In Procedia CIRP 26, 13-18. https://doi.org/10.1016/j.procir.2014.08.020

Long, J.S., 1997. Regression Models for Categorical and Limited Dependent Variables. Thousand Oaks, CA: Sage Publications.

Long, J.S., Freese, J., 2006. Regression Models for Categorical Dependent Variables Using Stata. Second edition. Stata Press

Lowe, G.D., Pinhey, T.K., 1982. Rural-Urban Differences in Support for Environmental Protection. Rural Sociology 47(1), 114-128.

Madden, D., 2008. Sample selection versus two-part models revisited: The case of female smoking and drinking. Journal of Health Economics 27(2), 300-307. https://doi.org/10.1016/j.jhealeco.2007.07.001

Manning, W.G., Mullahy, J., 2001. Estimating log models: to transform or not to transform? Journal of Health Economics 20(4), 461-494. https://doi.org/10.1016/s0167-6296(01)00086-8

Mayer, F.S., Frantz, C.M.P., 2004. The connectedness to nature scale: A measure of individuals' feeling in community with nature. Journal of Environmental Psychology 24(4), 503-515. https://doi.org/10.1016/j.jenvp.2004.10.001 
McCarthy, J.F., 2010. Processes of inclusion and adverse incorporation: Oil palm and agrarian change in Sumatra, Indonesia. Journal of Peasant Studies 37, 821-850. https://doi.org/10.1080/03066150.2010.512460

McKenzie, D., 2012: Beyond baseline and follow-up: The case for more T in experiments. In Journal of Development Economics 99 (2), 210-221. https://doi.org/10.1016/j.jdeveco.2012.01.002

Meinhold, J.L., Malkus, A.J., 2005. Adolescent environmental behaviors: Can knowledge, attitudes and self-efficacy make a difference? Environment and Behavior 37, 511-532. https://doi.org/10.1177/0013916504269665

Merten, J., Röll, A., Guillaume, T., Meijide, A., Tarigan, S., Agusta, H., Dislich, C., Dittrich, C., Faust, H., Gunawan, D., Hein, J., Hendrayanto, Knohl, A., Kuzyakov, Y., Wiegand, K., Hölscher, D., 2016. Water scarcity and oil palm expansion: social views and environmental processes. Ecology and Society 21(2). https://doi.org/10.5751/ES-08214-210205

Mileti, D., Sorensen, J., 1990. Communication of emergency public warnings: A social perspective and State-of-the-art assessment. Landslides 1, 52-70. https://doi.org/10.2172/6137387

Mobley, C., 2016. What Matters When Explaining Environmentalism at the Watershed Level: Who You Are, Where You Live, What You See, or What You Perceive? Environment and Behavior 48(9), 1148-1174. https://doi.org/10.1177/0013916515586058

Moffitt, R., Fitzgerald, J., Gottschalk, P., 1999. Sample Attrition in Panel Data: The Role of Selection on Observables. Annale d'Economie et de Statistique 55/56, 129-152.

https://doi.org/10.2307/20076194

Moss, S., Prosser, H., Costello, H., Simpson, N., Patel, P., Rowe, S., Turner, S., Hatton C., 1998. Reliability and validity of the PAS-ADD Checklist for detecting psychiatric disorders in adults with intellectual disability. Journal of Intellectual Disability Research 42(2), 173-183. https://doi.org/10.1046/j.1365-2788.1998.00116.x

Mulenga, B.P., Wineman, A., Sitko, N.J., 2017. Climate Trends and Farmers' Perceptions of Climate Change in Zambia. Environmental Management 59(2), 291-306.

Muttarak, R., Lutz, W., 2014. Is education a key to reducing vulnerability to natural disasters and hence unavoidable climate change? Ecology \& Society 19(1), 42. https://doi.org/10.5751/ES06476-190142

Naylor, R.L., Higgins, M.M., Edwards, R.B., Falcon, W.P., 2019. Decentralization and the environment: Assessing smallholder oil palm development in Indonesia. Ambio 48, 1195-1208. https://doi.org/10.1007/s13280-018-1135-7

Obidzinski, K., Andriani, R., Komarudin, H., Andrianto, A., 2012. Environmental and social impacts of oil palm plantations and their implications for biofuel production in Indonesia. Ecology and Society 17(1), 25. https://doi.org/10.5751/ES-04775-170125 
Omotilewa, O.J., Ricker-Gilbert, J., Ainembabazi, J.H., 2019. Subsidies for agricultural technology adoption: Evidence from randomized experiment in Uganda. American Journal of Agricultural Economics 101(3), 753-772. https://doi.org/10.1093/ajae/aay108

Outes-Leon, I., Dercon, S., 2008. Survey Attrition and Attrition Bias in Young Lives. Young Lives Technical Note 5, Young Lives, University of Oxford.

Pacheco, P., Gnych, S., Dermawan, A., Komarudin, H., Okarda, B., 2017. The palm oil global value chain: Implications for economic growth and social and environmental sustainability, The palm oil global value chain: Implications for economic growth and social and environmental sustainability. Center for International Forestry Research (CIFOR). https://doi.org/10.17528/cifor/006405

Parsons, H.M., 1974. What Happened at Hawthorne? Science 183(4128), 922-932. https://doi.org/10.1126/science.183.4128.922

Paterson, R.R.M., Sariah, M., Lima, N., 2013. How will climate change affect oil palm fungal diseases? Crop Protection 46, 113-120. https://doi.org/10.1016/j.cropro.2012.12.023

Paterson, R.R.M., Kumar, L., Taylor, S., Lima, N., 2015. Future climate effects on suitability for growth of oil palms in Malaysia and Indonesia. Scientific Reports 5, 14457. https://doi.org/10.1038/srep14457

Paterson, R.R.M., Lima, N., 2018. Climate change affecting oil palm agronomy, and oil palm cultivation increasing climate change, require amelioration. Ecology and Evolution 8, 452-461. https://doi.org/10.1002/ece3.3610

Peace, N., 2020. Impact of Climate Change on Insects, Pest, Diseases and Animal Biodiversity. International Journal of Environmental Sciences \& Natural Resources 23(5). https://doi.org/10.19080/ijesnr.2020.23.556123

Pisano, I., Lubell, M., 2017. Environmental Behavior in Cross-National Perspective: A Multilevel Analysis of 30 Countries. Environment and Behavior 49, 31-58. https://doi.org/10.1177/0013916515600494

Poortinga, W., Whitmarsh, L., Steg, L., Böhm, G., Fisher, S., 2019. Climate change perceptions and their individual-level determinants: A cross-European analysis. Global Environmental Change 55, 25-35. https://doi.org/10.1016/j.gloenvcha.2019.01.007

Potvin, C., Gotelli, N.J., 2008. Biodiversity enhances individual performance but does not affect survivorship in tropical trees. Ecology Letters 11(3), 217-223. https://doi.org/10.1111/j.14610248.2007.01148.x

Qaim, M., Sibhatu, K.T., Siregar, H., Grass, I., 2020. Environmental, Economic, and Social Consequences of the Oil Palm Boom. Annual Review of Resource Economics 12, 321-344. https://doi.org/10.1146/annurev-resource-110119-024922

Raihani, N.J., Mace, R., Lamba, S., 2013. The Effect of $\$ 1, \$ 5$ and $\$ 10$ Stakes in an Online Dictator Game. PLoS ONE 8(8), e0073131. https://doi.org/10.1371/journal.pone.0073131 
Rauwald, K.S., Moore, C.F., 2002. Environmental attitudes as predictors of policy support across three countries. Environment and Behavior 34, 709-739. https://doi.org/10.1177/001391602237243

Rist, L., Feintrenie, L., Levang, P., 2010. The livelihood impacts of oil palm: Smallholders in Indonesia. Biodiversity and Conservation 19(4), 1009-1024. https://doi.org/10.1007/s10531-010-9815-z

Rival, A., 2017. Breeding the oil palm (Elaeis guineensis Jacq.) for climate change. OCL - Oilseeds fats, Crop. Lipids 24. https://doi.org/10.1051/ocl/2017001

Rode, J., Gómez-Baggethun, E., Krause, T., 2015. Motivation crowding by economic incentives in conservation policy: A review of the empirical evidence. Ecological Economics 109, 80-92. https://doi.org/10.1016/j.ecolecon.2014.09.029

Romero, M., Wollni, M., Rudolf, K., Asnawi, R., Irawan, B., 2019. Promoting biodiversity enrichment in smallholder oil palm monocultures - Experimental evidence from Indonesia. World Development 124, 104638. https://doi.org/10.1016/j.worlddev.2019.104638

Rudolf, K., Romero, M., Asnawi, R., Irawan, B., Wollni, M., 2020. Effects of information and seedling provision on tree planting and survival in smallholder oil palm plantations. Journal of Environmental Economics and Management, 104, 102361. https://doi.org/10.1016/j.jeem.2020.102361

Rulli, M.C., Casirati, S., Dell'Angelo, J., Davis, K.F., Passera, C., D’Odorico, P., 2019. Interdependencies and telecoupling of oil palm expansion at the expense of Indonesian rainforest. Renewable and Sustainable Energy Reviews 105, 499-512. https://doi.org/10.1016/j.rser.2018.12.050

Santika, T., Wilson, K.A., Meijaard, E., Budiharta, S., Law, E.E., Sabri, M., Struebig, M., Ancrenaz, M., Poh, T.M., 2019. Changing landscapes, livelihoods and village welfare in the context of oil palm development. Land Use Policy 87, 104073. https://doi.org/10.1016/j.landusepol.2019.104073

Saphores, J.-D. M., Nixon, H., Ogunseitan, O. A., 2006. Household willingness to recycle electronic waste - An application to California. Environment and Behavior, 38(2), 183-208

Sayer, J., Ghazoul, J., Nelson, P., Boedhihartono, A.K., 2012. Oil palm expansion transforms tropical landscapes and livelihoods. Global Food Security 1, 114-119.

https://doi.org/10.1016/j.gfs.2012.10.003

Schultz, P.W., Gouveia, V.V., Cameron, L.D., Tankha, G., Schmuck, P., Franěk, M., 2005. Values and their relationship to environmental concern and conservation behavior. Journal of CrossCultural Psychology 36(4), 457-475. https://doi.org/10.1177/0022022105275962

Schwarze, S., Euler, M., Gatto, M., Hein, J., Hettig, E., Holtkamp, A.M., Izhar, L., Kunz, Y., Lay, J., Merten, J., Moser, S., Mußhoff, O., Otten, F., Qaim, M., 2015. Rubber vs. oil palm: an analysis of factors influencing smallholders' crop choice in Jambi, Indonesia.

https://doi.org/10.13140/RG.2.1.1695.0808 
Shang, J., Croson, R., 2009. A field experiment in charitable contribution: The impact of social information on the voluntary provision of public goods. Economic Journal 119(540), 1422-1439. https://doi.org/10.1111/j.1468-0297.2009.02267.x

Sharp, J., Adua, L., 2009. The social basis of agro-environmental concern: Physical versus social proximity. Rural Sociology 74(1), 56-85. https://doi.org/10.1526/003601109787524061

Simelton, E., Quinn, C.H., Batisani, N., Dougill, A.J., Dyer, J.C., Fraser, E.D.G., Mkwambisi, N., Sallu, S.M., Stringer, L.C., 2013. Is rainfall really changing? Farmers' perceptions, meteorological data, and policy implications. Climate and Development, 5, 123-138. https://doi.org/10.1080/17565529.2012.751893

Singh, R.K., Zander, K.K., Kumar, S., Singh, A., Sheoran, P., Kumar, A., Hussain, S.M., Riba, T., Rallen, O., Lego, Y.J., Padung, E., Garnett, S.T., 2017. Perceptions of climate variability and livelihood adaptations relating to gender and wealth among the Adi community of the Eastern Indian Himalayas. Applied Geography 86, 41-52. https://doi.org/10.1016/j.apgeog.2017.06.018

Sjahza, A., Asmit, B., 2019. Regional economic empowerment through oil palm economic institutional development. Management of Environmental Quality: An International Journal 30, 1256-1278. https://doi.org/10.1108/MEQ-02-2018-0036

Sjöberg, L., 1989. Global change and human action: Psychological perspectives. International Social Science Journal 121, 414-432.

Slingerland, M., Khasanah, N., van Noordwijk, M., Susanti, A., Meilantina, M., 2019. Improving smallholder inclusivity through integrating oil palm with crops. In Rosalien Jezeer, Nick Pasiecznik (Eds.): Exploring inclusive Palm oil production, 147-154.

Stern, N., 2007. The Economics of Climate Change: the Stern Review. Cambridge University Press, Cambridge, UK.

Stern, P.C., Dietz, T., Guagnano, G.A., 1995. The New Ecological Paradigm in Social-Psychological Context. Environment and Behaviour 27(6), 723-743. https://doi.org/10.1177/0013916595276001

Stevenson, K.T., Peterson, M.N., Bondell, H.D., Moore, S.E., Carrier, S.J., 2014. Overcoming skepticism with education: interacting influences of worldview and climate change knowledge on perceived climate change risk among adolescents. Climatic Change 126, 293-304. https://doi.org/10.1007/s10584-014-1228-7

Stibig, H.J., Achard, F., Carboni, S., Raši, R., Miettinen, J., 2014. Change in tropical forest cover of Southeast Asia from 1990 to 2010. Biogeosciences 11, 247-258. https://doi.org/10.5194/bg-11247-2014

Takala, M., 1991. Environmental awareness and human activity. International Journal of Psychology 26, 585-597. https://doi.org/10.1080/00207599108247146

Teuscher, M., Gérard, A., Brose, U., Buchori, D., Clough, Y., Ehbrecht, M., Hölscher, D., Irawan, B., Sundawati, L., Wollni, M., Kreft, H., 2016. Experimental biodiversity enrichment in oil-palm- 
dominated landscapes in Indonesia. Frontiers in Plant Science 7, 1-15.

https://doi.org/10.3389/fpls.2016.01538

Tremblay, K.R., Dunlap R.E., 1978. Rural Residence and Concern with Environmental Quality: A Replication and Extension. Rural Sociology 43(3), 474-91.

Ullah, W., Nafees, M., Khurshid, M., Nihei, T., 2019. Assessing farmers' perspectives on climate change for effective farm-level adaptation measures in Khyber Pakhtunkhwa, Pakistan. Environmental Monitoring and Assessment, 191(9), 547. https://doi.org/10.1007/s10661-0197651-5

Van Campenhout, B., 2019. The Role of Information in Agricultural Technology Adoption: Experimental Evidence from Rice Farmers in Uganda. Economic Development and Cultural Change. https://doi.org/10.1086/703868

Van Noordwijk M., Hoang M.H., Neufeldt H., Öborn I., Yatich T., 2011. How trees and people can coadapt to climate change: reducing vulnerability through multifunctional agroforestry landscapes. World Agroforestry Centre (ICRAF): Nairobi, Kenya.

Van Straaten, O., Corre, M.D., Wolf, K., Tchienkoua, M., Cuellar, E., Matthews, R.B., Veldkamp, E., 2015. Conversion of lowland tropical forests to tree cash crop plantations loses up to one-half of stored soil organic carbon. Proceedings of the National Academy of Sciences of the United States of America 112(32), 9956-9960. https://doi.org/10.1073/pnas.1504628112

Varkkey, H., 2013. Oil palm plantations and transboundary haze: Patronage networks and land licensing in Indonesia's peatlands. Wetlands 33(4), 679-690. https://doi.org/10.1007/s13157013-0423-z

Verges, M., Duffy, S., 2010. Connected to Birds but Not Bees: Valence Moderates Implicit Associations with Nature. Environment and Behavior 42(5), 625-642. https://doi.org/10.1177/0013916508330210

Villamor, G., Akiefnawati, R., Van Noordwijk, M., Desrianti, F., Pradhan, U., 2015. Land use change and shifts in gender roles in central Sumatra, Indonesia. International Forestry Review 17(1), 115. https://doi.org/10.1505/146554815816002211

Vorkinn, M., Riese, H., 2001. Environmental concern in a local context. The Significance of Place Attachment. Environment and Behavior 33(2), 249-263. https://doi.org/10.1177/00139160121972972

Watson K., Halse C.M., 2005. Environmental Attitudes of Pre-service Teachers: A Conceptual and Methodological Dilemma in Cross-Cultural Data Collection. Asia Pacific Education Review 6(1), 59-71. https://doi.org/10.1007/BF03024968

Weigel, R.H., 1983. Environmental attitudes and prediction of behavior. In Feimer, N.R., Geller, E.S. (Eds), Environmental Psychology: Directions and Perspectives, Praeger, New York, NY, 257-287.

Wen, L.M., Rissel, C., Baur, L.A., Lee, E., Simpson, J.M., 2011. Who is NOT likely to access the Internet for health information Findings from first-time mothers in southwest Sydney, Australia. 
International Journal of Medical Information 80, 406-411.

https://doi.org/10.1016/j.ijmedinf.2011.03.001

Wheeler, D., Hammer, D., Kraft, R., Dasgupta, S., Blankespoor, B., 2013. Economic dynamics and forest clearing: a spatial econometric analysis for Indonesia. Ecological Economics 85, 85-96. https://doi.org/10.1016/j.ecolecon.2012.11.005

Winking, J., 2014. Anonymity versus privacy in the dictator game: Revealing donor decisions to recipients does not substantially impact donor behavior. PLoS ONE, 9(12). https://doi.org/10.1371/journal.pone.0115419

Wooldridge, J.M., 2010. Econometric analysis of cross section and panel data. 2nd edition, Cambridge, Mass.: MIT Press.

World Meteorological Organization (WMO), 2020. WMO Provisional Report on the State of the Global Climate 2020.

Yao, K., 2015. Who Gives? The Determinants of Charitable Giving, Volunteering, and Their Relationship. Working paper. Wharton School. Retrieved from http://repository.upenn.edu/wharton_research_scholars/126

Yu, X., 2014. Is environment "a city thing" in China? Rural-urban differences in environmental attitudes. Journal of Environmental Psychology 38, 39-48.

https://doi.org/10.1016/j.jenvp.2013.12.009

Zhao, S., Peng, C., Jiang, H., Tian, D., Lei, X., Zhou, X., 2006. Land use change in Asia and the ecological consequences. Ecological Research 21, 890-896. https://doi.org/10.1007/s11284-006-0048-2 


\section{General appendix}

\section{Appendix Chapters 2 and 3}

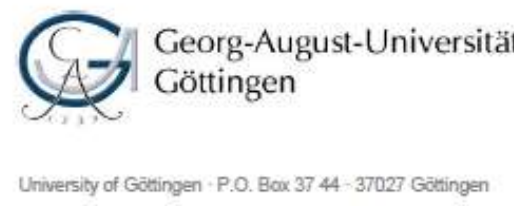

Ethikkommission

University of Götingen +P.O. Box 37 44-37027 Götingen

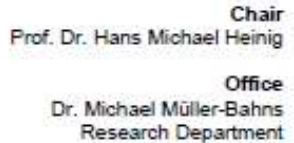

Göttingen, 24 June 2019

\section{Comment on the project}

"Policy incentives for sustainable land use choices"

PhD Candidate Karina Brenneis

Environmental and Resource Economics

Georg-August-Universität Göttingen

To whom it may concem,

From the perspective of the ethics committee of the University of Göttingen, there are no objections conceming the implementation of the project as requested, as long as the data protection provisions have been taken into account.

Yours sincerely,

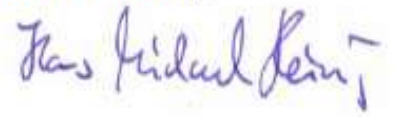

Prof. Dr. H. M. Heinig

(Chair) 


\section{Declarations}

1. I hereby declare that this Ph.D. dissertation has not been presented to any other examining body in its present or a similar format.

I also affirm that I have not applied for a Ph.D. at any other higher educational institution.

Göttingen, 03.09.2021

(Signature)

(Name in block capitals)

2. I hereby declare that this dissertation was undertaken independently and without unauthorized assistance.

Göttingen, 03.09.2021

(Signature)

(Name in block capitals) 